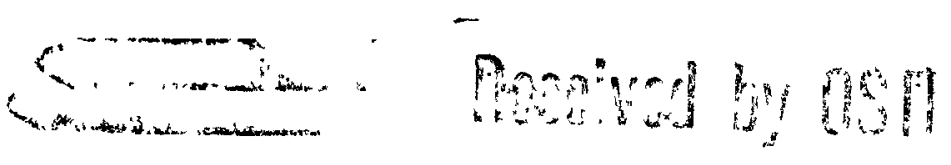

FEB 221988

\title{
Assessment of the Use of Extended Burnup Fuel in Light Water Power Reactors
}

\section{DO NOT MICROFILM COVER}

Prepared by D.A. Baker, W.J. Bailey, C.E. Beyer, F.C. Bold, J.J. Tawil

Pacific Northwest Laboratory

Operated by

Battelle Memorial Institute

Prepared for

U.S. Nuclear Regulatory

Commission 


\section{DISCLAIMER}

This report was prepared as an account of work sponsored by an agency of the United States Government. Neither the United States Government nor any agency Thereof, nor any of their employees, makes any warranty, express or implied, or assumes any legal liability or responsibility for the accuracy, completeness, or usefulness of any information, apparatus, product, or process disclosed, or represents that its use would not infringe privately owned rights. Reference herein to any specific commercial product, process, or service by trade name, trademark, manufacturer, or otherwise does not necessarily constitute or imply its endorsement, recommendation, or favoring by the United States Government or any agency thereof. The views and opinions of authors expressed herein do not necessarily state or reflect those of the United States Government or any agency thereof. 


\section{DISCLAIMER}

Portions of this document may be illegible in electronic image products. Images are produced from the best available original document. 
This report was prepared as an account of work sponsored by an agency of the United States Government Neither the United States Government nor any agency thereof, or any of their employees, makes any warranty, expressed or implied, or assumes any legal liability of re sponsibility for any third party's use, or the results of such use, of any information, apparatus, product or process disclosed in this report, or represents that its use by such third party would not infringe privately owned rights

\section{NOTICE}

Avallability of Reference Materials Cited in NRC Publications

Most documents cited in NRC publications will be available from one of the following sources

1 The NRC Public Document Room, 1717 H Street, N W Washıngton, DC 20555

2 The Superıntendent of Documents, U S Government Prıntıng Office Post Office Box 37082 Washıngton, DC 20013-7082

3 The National Technical Information Service, Springfield, VA 22161

Although the listing that follows represents the majority of documents cited in NRC publications it is not intended to be exhaustive

Referenced documents avalable for inspection and copying for a fee from the NRC Public Docu ment Room include NRC correspondence and internal JPC memoranda NRC Office of Inspection and Enforcement bulletıns, circulars, information notices, inspection and investigation notices Licensee Event Reports, vendor reports and correspondence, Commission papers and applicant and licensee documents and correspondence

The following documents in the NUREG series are avallable for purchase from the GPO Sales Program formal NRC staff and contractor reports, NRC sponsored conference proceedings and NRC booklets and brochures Also avallable are Regulatory Guides, NRC regulations in the Code of Federal Regulations, and Nuclear Regulatory Commission /ssuances

Documents avallable from the National Technical Information Service include NUREG series reports and technical reports prepared by other federal agencies and reports prepared by the Atomic Energy Commission, forerunner agency to the Nuclear Regulatory Commission

Documents available from public and special technical libraries include all open literature items, such as books, journal and perıodical articles, and transactions Federal Register notıces federal and state legislation, and congressional reports can usually be obtained from these libraries

Documents such as theses, dissertations, foreign reports and translations, and non NRC conference proceedings are available for purchase from the organization sponsoring the publication cited

Single copıes of NRC draft reports are avallable free, to the extent of supply, upon written request to the Division of Information Support Services, Distribution Section, U S Nuclear Regulatory Commission, Washıngton, DC 20555

Copies of industry codes and standards used in a substantive manner in the NRC regulatory process are maintained at the NRC Library, 7920 Norfolk Avenue, Bethesda, Maryland, and are avallable there for reference use by the public Codes and standards are usually copyrighted and may be purchased from the originating organization or, if they are American National Standards from the American National Standards Instıtute, 1430 Broadway, New York, NY 10018 


\section{NOTICE}

This report was prepared as an account of work sponsored by an agency of the United States Government Neither the United States Government nor any agency thereof, or any of their employees. makes any warranty, expressed or implied, or assumes any legal liability of re sponsibility for any third party's use or the results of such use, of any information, apparatus product or process disclosed in this report or represents that its use by such third party would not infringe privately owned rights

\section{NOTICE}

\section{Avallability of Reference Materials Cited in NRC Publications}

Most documents cited in NRC publications will be avallable from one of the following sources

1 The NRC Public Document Room, 1717 H Street, N W Washıngton, DC 20555

2 The Superintendent of Documents U S Government Printing Office Post Office Box 37082 Washıngton, DC 200137082

3 The National Technical Information Service, Springfield VA 22161

Although the listing that follows represents the majority of documents cited in NRC publica. uns it is not intended to be exhaustive

Referenced documents avallable for inspection and copying for a fee from the NRC Public Docu ment Room include NRC correspondence and internal NRC memoranda NRC Office of Ii spection and Enforcement bulletins circulars information notices, inspection and investigation notices Licensee Event Reports, vendor reports and correspondence, Commission papers and applicant and licensee documents and correspondence

The following documents in the NUREG series are avallable for purchase from the GPO Sales Program formal NRC staff and contractor reports, NRC sponsored conference proceedings and NRC booklets and brochures Also avallable are Regulatory Guides, NRC regulations in the Code of Federal Regulations, and Nuclear Regulatory Commission /ssuances

Documents avalable from the National Technical Information Service include NUREG series reports and technical reports prepared by other federal agencies and reports prepared by the Atomic Energy Commission, forerunner agency to the Nuclear Regulatory Commission

Documents avallable from public and special technical libraries include all open literature items, such as books, journal and periodical articles, and transactions Federal Register notices, federal and state legislation, and congressional reports can usually be obtained from these libraries

Documents such as theses, dissertations, foreign reports and translations, and non NRC conference proceedings are available for purchase from the organization sponsoring the publication cited

Single copies of NRC draft reports are avallable free, to the extent of supply, upon written request to the Division of Information Support Services, Distribution Section, U.S. Nuclear Regulatory Commission, Washington, DC 20555

Copies of industry codes and standards used in a substantive manner in the NRC regulatory process are maintained at the NRC Library, 7920 Norfolk Avenue, Bethesda, Maryland, and are avallable there for reference use by the public Codes and standards are usually copyrighted and may be purchased from the originatıng organization or. If they are American National Standards, from the American National Standards Institute, 1430 Broadway, New York, NY 10018 
NUREG/CR-5009

PNL-6258

RE, $1 S$

\title{
Assessment of the Use of Extended Burnup Fuel in Light Water Power Reactors
}

NUREG/CR--5009

TI88 006080

Manuscript Completed: January 1988

Date Published: February 1988

Prepared by D.A. Baker, W.J. Bailey, C.E. Beyer, F.C. Bold, J.J. Tawil

Pacific Northwest Laboratory

Richland, Washington 99352

\author{
Prepared for \\ Division of Regulatory Applications \\ Office of Nuclear Regulatory Research \\ U.S. Nuclear Regulatory Commission \\ Washington, DC 20555 \\ NRC FIN B2894
}

\section{DISCLAIMER}

This report was prepared as an account of work sponsored by an agency of the United States Government. Neither the United States Government nor any agency thereof, nor any of their employees, makes any warranty, express or implied, or assumes any legal liability or responsibility for the accuracy, completeness, or usefulness of any information, apparatus, product, or process disclosed, or represents that its use would not infringe privately owned rights. Reference herein to any specific commercial product, process, or service by trade name, trademark, manufacturer, or otherwise does not necessarily constitute or imply its endorsement, recommendation, or favoring by the United States Government or any agency thereof. The views and opinions of authors expressed herein do not necessarily state or reflect those of the United States Government or any agency thereof. 


\section{ABSTRACT}

This study has been conducted by Pacific Northwest Laboratory (a) for the U.S. Nuclear Regulatory Commission to review the environmental and economic impacts associated with the use of extended burnup nuclear fuel in light water power reactors. Some nuclear power plant licensees have requested authorization to increase their current batch average burnup levels of $33 \mathrm{GWd} / \mathrm{t}$ uranium to levels above $50 \mathrm{GWd} / \mathrm{t}$. The environmental effects of extending fuel burnup are discussed with respect to normal operations, to accident events, and to the economic effects on the fuel cycle. The physical effects of extended burnup on the fuel and the fuel assembly are also presented as a basis for the environmental and economic assessments.

Environmentally, this burnup increase would have no significant impact over that of normal burnup. Economically, the increased burnup would have favorable effects, consisting primarily of a reduction in 1) total fuel requirements, 2) reactor downtime for fuel replacement, 3) the number of fuel shipments to and from reactor sites, and 4) repository storage requirements.

(a) Pacific Northwest Laboratory is operated by Battelle Memorial Institute for the U.S. Department of Energy. 



\section{CONTENTS}

ABSTRACT

ACKNOWLEDGMENTS

$x i$

GLOSSARY

xiii

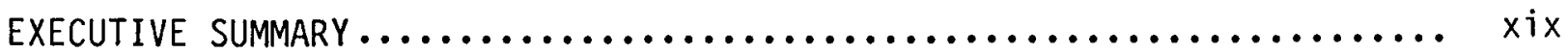

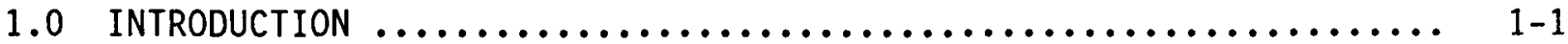

1.1 DISCUSSION OF THE PETITION..................... 1-1

1.2 EXPLANATION OF EXTENDED BURNUP FUEL $\ldots \ldots \ldots \ldots \ldots \ldots \ldots \ldots \ldots \ldots$

1.3 PROJECTED INDUSTRY USAGE OF EXTENDED BURNUP FUEL $\ldots \ldots \ldots \ldots \ldots 1-2$

1.4 U.S. LICENSING EXPERIENCE OF REACTORS USING

EXTENDED BURNUP FUEL $\ldots \ldots \ldots \ldots \ldots \ldots \ldots \ldots \ldots \ldots \ldots \ldots \ldots \ldots$. $1-6$

1.5 FUEL OPERATING EXPERIENCE AT EXTENDED BURNUP $\ldots \ldots \ldots \ldots \ldots \ldots \ldots$

2.0 PHYSICAL EFFECTS $\ldots \ldots \ldots \ldots \ldots \ldots \ldots \ldots \ldots \ldots \ldots \ldots \ldots \ldots \ldots \ldots \ldots \ldots$

2.1 PHYSICAL EFFECTS ON FUEL AT EXTENDED BURNUP $\ldots \ldots \ldots \ldots \ldots \ldots \ldots$.

2.2 FISSION-PRODUCT RELEASE FROM FUEL AT EXTENDED BURNUP ...... 2-6

3.0 ENVIRONMENTAL EFFECTS $\ldots \ldots \ldots \ldots \ldots \ldots \ldots \ldots \ldots \ldots \ldots \ldots \ldots \ldots \ldots \ldots$

3.1 EFFECTS FROM NORMAL OPERATION $\ldots \ldots \ldots \ldots \ldots \ldots \ldots \ldots \ldots \ldots \ldots \ldots \ldots \ldots \ldots . \ldots \ldots$

3.1 .1 Mining and Milling .......................... $3-3$

3.1 .2 Conversion and Enrichment ..................... 3-3

3.1 .3 Fuel Fabrication ............................ 3-3

3.1 .4 Refueling ................................ $3-3$

3.1 .5 Reactor Operation .............................. 3-3

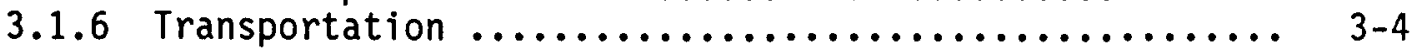

3.1 .7 Waste Management .......................... 3-7

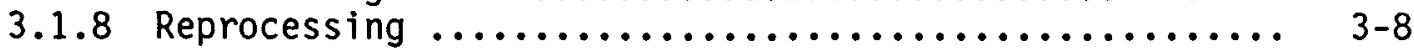

3.2 EFFECTS FROM ACCIDENTS $\ldots \ldots \ldots \ldots \ldots \ldots \ldots \ldots \ldots \ldots \ldots \ldots \ldots \ldots$

3.2.1 Fuel-Damage Accident ....................... 3-8

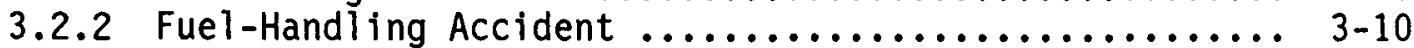

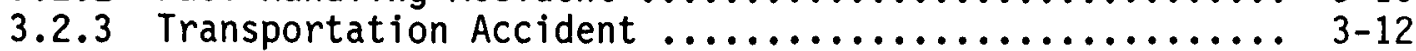

3.3 SUMMARY OF ENVIRONMENTAL EFFECTS $\ldots \ldots \ldots \ldots \ldots \ldots \ldots \ldots \ldots \ldots$

4.0 ECONOMIC EFFECTS $\ldots \ldots \ldots \ldots \ldots \ldots \ldots \ldots \ldots \ldots \ldots \ldots \ldots \ldots \ldots \ldots \ldots \ldots$

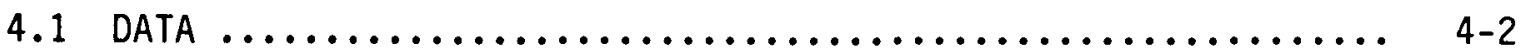


4.2 FRONT-END EFFECTS $\ldots \ldots \ldots \ldots \ldots \ldots \ldots \ldots \ldots \ldots \ldots \ldots \ldots \ldots, 4-4$

4.2.1 Front-End Research $\ldots \ldots \ldots \ldots \ldots \ldots \ldots \ldots \ldots \ldots \ldots, 4,4$

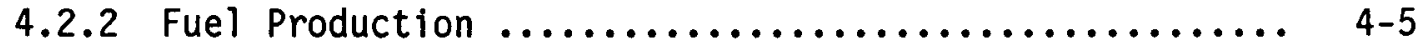

4.2.3 Fuel Management $\ldots \ldots \ldots \ldots \ldots \ldots \ldots, \ldots \ldots, \ldots, \ldots, \ldots, 4,11$

4.2.4 Aggregate Front-End Effects $\ldots \ldots \ldots \ldots \ldots \ldots \ldots \ldots, 4,12$

4.3 BACK-END EFFECTS $\ldots \ldots \ldots \ldots \ldots \ldots \ldots \ldots \ldots \ldots \ldots \ldots \ldots . \ldots . \ldots . \ldots \ldots$

4.3.1 Development and Evaluation $. . . \ldots \ldots \ldots \ldots \ldots, \ldots, \ldots, \ldots, 4,13$

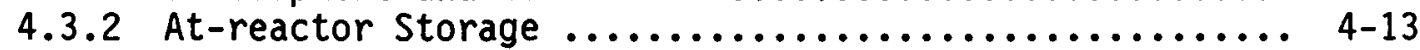

4.3 .3 Transportation $\ldots \ldots \ldots \ldots \ldots \ldots \ldots \ldots \ldots \ldots \ldots \ldots \ldots, 4,14$

4.3 .4 Repository Storage $\ldots \ldots \ldots \ldots \ldots \ldots \ldots \ldots \ldots \ldots \ldots \ldots, 4,18$

4.3.5 Back-End Total costs ......................... 4-21

4.4 TOTAL FUEL CYCLE $\ldots \ldots \ldots \ldots \ldots \ldots \ldots \ldots \ldots \ldots \ldots \ldots \ldots \ldots, 4-22$

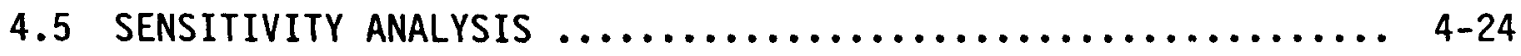

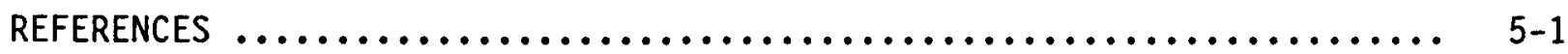

APPENDIX A - FUEL ACTIVITY INVENTORY CALCULATIONAL PARAMETERS ....... A-1

APPENDIX B - COST ADJUSTMENT METHODOLOGY ..................... B-1 


\section{FIGURES}

1.1 Example of a BWR Fuel Assembly $\ldots \ldots \ldots \ldots \ldots \ldots \ldots \ldots \ldots \ldots \ldots . . . \ldots$

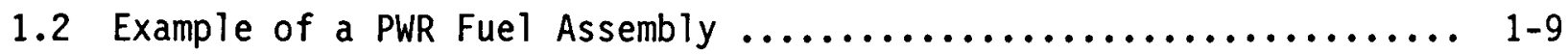

2.1 Cross-Section of a Uranium Oxide Fuel Rod for a

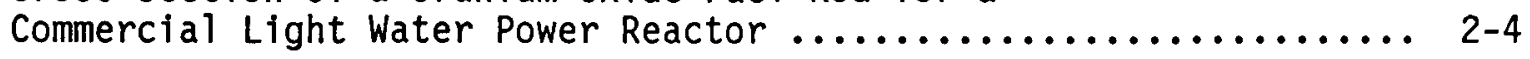

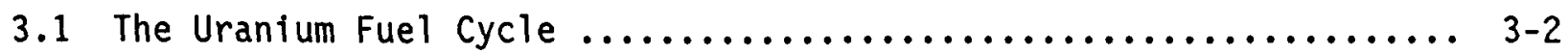




\section{TABLES}

S.1 Summary of Changes in Radiological Impacts for Various Fuel-

Cycle Activities with the Implementation of Extended Burnup Fuel .. xx

S.2 Summary of Estimated Discounted cost Savings

from Extended Fuel Burnup by Activity, 1985-2020 .............. xxii

1.1 Projections of U.S. Nuclear Generating Capacity ............... 1-2

1.2 Projected Implementation Schedule for Extended Burnup Fuel Use .... 1-3

1.3 Alternate Forecasts of Batch Average Burnup Levels by Reactor Type and Date of Fuel Loading, 1980-2020 .............. 1-4

1.4 Aggregate Average Burnup of Spent Fuel at Discharge by Fuel Type and Year of Discharge from Reactor $\ldots \ldots \ldots \ldots \ldots \ldots .1-4$

1.5 Forecasts of Spent-Fuel Discharges and Burnup Levels by Implementation Schedule and Year, $1985-2020 \ldots \ldots \ldots \ldots .1-5$

1.6 Comparison of PWR Burnup Level Forecasts

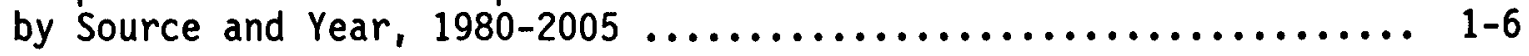

2.1 Fuel Assembly Performance Considerations $\ldots \ldots \ldots \ldots \ldots \ldots \ldots \ldots .2-2$

2.2 Radionuclides Contributing to Environmental Impacts from Normal Operational and Accidental Releases to Biosphere Showing the Change Factor at Shutdown Resulting from an Increase in Burnup Level from 33 to $60 \mathrm{GWd} / \mathrm{t} \ldots \ldots \ldots \ldots . . \ldots . . .2-8$

3.1 Major Contributory Radionuclides for Burnups of 33 and $60 \mathrm{GWd} / \mathrm{t}$ Released into the Cooling System During Normal Operation,

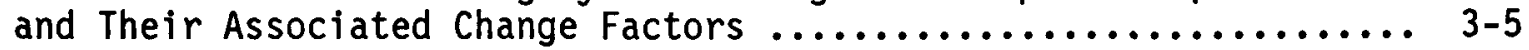

3.2 Estimated Population Doses to Workers and the General Public for Three Types of Spent-Fuel Carriers

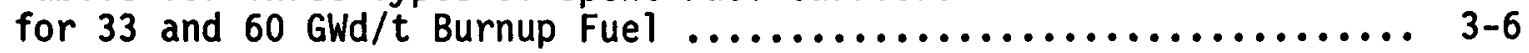

3.3 Estimated Population Doses to Workers and the General Public for Solid Waste Shipments by Truck for

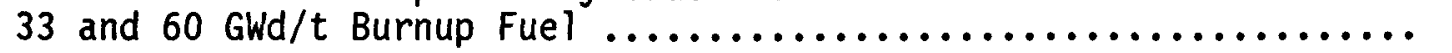

3.4 Summary of Changes in Radiological Impacts for Various WasteManagement Activities for Increasing Fuel Burnup from 33 to

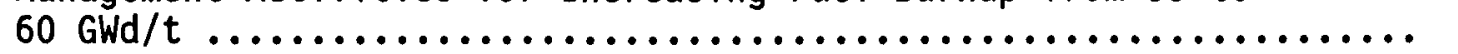

3.5 Summary of Changes in Radiological Impacts from Reprocessing for

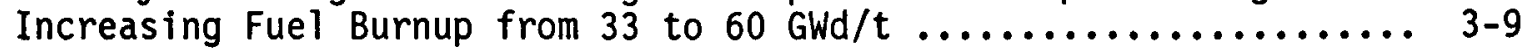


3.6 Calculated Release Fractions in the Fuel-Cladding Gap of the Peak Fuel Rod During Normal Operation at Current and Extended Burnup Levels of 33 and $60 \mathrm{GWd} / \mathrm{t}$ Compared with Gap-Release Fractions Assumed in Regulatory Guides .................... 3-12

3.7 Major Contributing Radionuclides Resulting from a Transportation Accident Involving the Release of Spent Fuel ............... 3-13

3.8 Summary of Changes in Radiological Impacts for Various Fuel-Cycle Activities with the Implementation of Extended Burnup Fuel ...... 3-14

4.1 Comparisons of Forecasted Spent-Fuel Discharges With and Without Implementation of Extended Burnup by Year, 1985-2020 ......... 4-2

4.2 Projected DOE Research and Development Expenditures for New Extended Burnup Projects by Year, 1987-1994 ................. 4-5

4.3 Annualized Reference Reactor Year Uranium Ore Requirements With and Without Reprocessing, by Burnup Level .............. 4-7

4.4 Annualized Reference Reactor Year Milling Requirements With and Without Reprocessing, by Burnup Leve1 .................. 4-8

4.5 Forecasted Milling Costs by Year, $1985-2000 \ldots \ldots \ldots \ldots \ldots \ldots \ldots \ldots$

4.6 Forecasted Conversion Costs by Year, 1985-2000 .............. 4-8

4.7 Annualized Reference Reactor Year Separative Work Unit Requirements With and Without Uranium Recycling, by Burnup Level

4.8 Annualized Reference Reactor Year Fuel Requirements by Burnup Level

4.9 Annualized Reference Reactor Year Transportation Requirements for Unirradiated Fuel, by Burnup Level .................... 4-11

4.10 Back-End Transportation Costs, 1984-2020, by Repository Type and Burnup Level ................................. 4-15

4.11 Estimated Back-End Transportation Costs, 1984-2020, by Spent-Fuel Age and Burnup Level .............................. 4-16

4.12 Annualized Reference Reactor Year Transportation Requirements for Spent Fuel, by Burnup Level .............. 4-18

4.13 Total Undiscounted Repository Costs by Spent-Fuel Age and Burnup Leve1 ................................ 4-19

4.14 Repository Costs, 1984-2020, by Burnup Level and Repository Type ................................... 4-19 
4.15 Total Discounted Repository Costs by SpentFuel Age and Burnup Level ........................... 4-20

4.16 Estimated Discounted Repository Costs, 1984-2020, by Burnup Level and Repository Type ..................... 4-20

4.17 Summary of Estimated 1985 Discounted Back-End Cost Savings, 1985-2020, by Data Source and Cost Category ................ 4-22

4.18 Estimated Savings Resulting from Implementation of Extended Burnup by Category ....................... 4-23

4.19 Summary of Estimated Discounted Cost Savings, 1985-2020, from Extended Fuel Burnup, by Category .................. 4-26 


\section{ACKNOWLEDGMENTS}

We wish to express our gratitude to Morton R. Fleishman, Office of Nuclear Regulatory Research, U.S. Nuclear Regulatory Commission, for his ideas, support, discussion, and assistance in this work. We also thank J. B. Brown, Jr., for technical peer review, V. L. Brouns for technical editing, and A. Jewell and C. F. Schauls for word processing. 



\section{GLOSSARY}

Absorbed dose - The amount of energy in the form of ionizing radiation absorbed in a unit mass of matter. The unit is gray $(G y)=1$ joule $/$ kilogram $(\mathrm{kg})=$ $100 \mathrm{rad}$.

Actinide - A radioactive nuclide having an atomic number greater than that of radium, which is 88 .

Activity - A measure of the rate at which material is emitting nuclear radiations; radioactivity is usually given in terms of the number of nuclear disintegrations occurring in a given quantity of matter over a period of time. The unit of activity is the becquerel $(\mathrm{Bq})=1$ disintegration/ second $=27$ picocurie $(\mathrm{pCi})$.

At-reactor storage - Temporary storage of spent-fuel assemblies in pools of water at reactor sites.

Average individual - An individual of the general public whose habits are average for the general population.

Back end - Pertaining to activities associated with the uranium fuel cycle after removal of spent fuel from a reactor, such as at-reactor storage, transportation to reprocessing plants or waste repositories, and final burial if not reprocessed. Also included is development and evaluation related to these activities.

Batch average burnup - The average (arithmetic mean) of the burnup of all fuel assemblies in the quantity of fuel to be replaced at a single fuelreplacement outage.

Biotransfer factor - Ratio of the concentration of activity in food crop to that of soil; concentration factor.

Boiling water reactor (BWR) - A light water reactor in which water, used as both coolant and moderator, is allowed to boil in the reactor core. The resulting steam can be used directly to drive a turbine.

Burnup - A measure of nuclear reactor fuel consumption; the quantity of energy generated by a unit amount of uranium fuel in a nuclear reactor, usually expressed as the average power multiplied by the days of exposure in the core per unit mass of uranium: 1,000 megawatt-days/tonne $(\mathrm{MWd} / \mathrm{t})=$ 1 gigawatt-day/tonne $(\mathrm{GWd} / \mathrm{t})=1$ megawatt-day $/ \mathrm{ki} \operatorname{logram}(\mathrm{MWd} / \mathrm{kg})$.

Capacity - The electrical power generating load for which a plant is rated. Also the total capacity of a set of plants such as the nuclear plants in the United States.

Capacity factor - The ratio of actual power generated to the amount that would have been generated, had the reactor operated at rated capacity for the same period, usually a year. 
Cladding - The outer metal jacket of nuclear fuel rods. It prevents the corrosion of the fuel and release of fission products into the coolant.

Class 9 accident - An accident that involves substantial physical deterioration of the fuel in the reactor core, including overheating to the point of melting, and involves deterioration of the containment system (filters, sprays, etc.) to perform its intended function of limiting the release of radioactive materials to the environment.

Conversion - The stage of fuel production in which yellowcake $\left(\mathrm{U}_{3} \mathrm{O}_{8}\right)$ is converted to uranium hexafluoride $\left(\mathrm{UF}_{6}\right)$.

Curie (Ci) - 0ld unit of activity defined as the amount of a radioactive material that has an activity of $3.7 \times 10^{10}$ disintegrations/second. Now being replaced by the becquerel. (See activity.)

Disaggregate - To separate into component parts.

Discharge burnup - Average burnup level of discharged fuel batch.

Distribution factor - The factor used in computing dose equivalent to allow for the nonuniform distribution of internally deposited radionuclides.

Dose - In this report, "dose" is used to designate the dose equivalent in rem. (See dose equivalent.)

Dose commitment - The integrated dose that results from external exposure to, or an intake of, radioactive material when dose is evaluated from the beginning of exposure or intake to a later time (usually 50 years).

Dose equivalent - The product of absorbed dose, quality factors, dose distribution factor, and other necessary modifying factors. The unit is the sievert $(\mathrm{Sv})=100 \mathrm{rem}$.

Dose equivalent commitment - The infinite time integral of the per capita dose-equivalent rate in a given organ or tissue for a specified population.

Enrichment - The process by which the abundance of the isotope uranium-235 in natural uranium is increased above normal $(0.7 \%)$. For standard burnup levels, the enrichment level is around 3.5\%. For extended burnup, the appropriate enrichment level is about $4 \%$ to $5 \%$. The amount of enrichment processing is measured in SWUs (separative work units.)

Fabrication - Stage of fuel production in which the enriched fuel $\left(\mathrm{UO}_{2}\right)$ is formed into pellets and placed into fuel-rod assemblies.

Fission products - The nuclei (fission fragments) formed by the fission of heavy elements, plus the nuclides formed by the radioactive decay of fission fragments. 
Front end - Pertaining to those activities of the uranium fuel cycle ending in reactor operation such as mining, processing, converting, and enriching the uranium, and the fabrication into fuel assemblies and final transportation to the reactor site. Also included is research and development related to these stages.

Fuel - Fissionable material used as the source of power when placed in a critical arrangement in a nuclear reactor. The fuel is in the form of pellets contained in rods that are distributed in an array (typically square: $8 \times 8,17 \times 17$, etc.) contained within a fuel assembly.

Fuel cycle - The various activities or processes undergone by reactor fuel, from mining of the ore to storage of nuclear waste in a repository.

Fuel management - Decisions and operations relating to burnup of fuel in the reactor. These decisions concern such matters as the length of time fuel remains in reactor core, the frequency of fuel reloading, and the proportion of total fuel replaced during reloading. Another decision pertains to the placement of fuel assemblies of different age in the reactor core.

Fuel production - The five processing stages (mining, milling, conversion, enrichment, fabrication) necessary to produce reactor fuel.

Gap-release fraction - The fraction of the fission products that migrates from the fuel matrix to the region between fuel pellets and fuel cladding during normal operation and which would be available for immediate release into the cooling water in the event of clad damage.

Generating capacity - (See capacity.)

General population - Group or population not employed in occupations dealing with radioactive materials.

Half-life - The time required for the activity of a radionuclide to decay to half its value; used as a measure of persistence of radioactive materials.

Light water reactor (LWR) - A nuclear reactor that uses water as the primary coolant and moderator, with slightly enriched uranium as fuel. (See boiling water reactor and pressurized water reactor.)

Man-rem - Unit used to compare the effects of different amounts of radiation on groups of people. It is obtained by multiplying the average dose equivalent to a given organ or tissue ( $\mathrm{rem}$ ) by the number of persons making up the population group. Sometimes given as person-rem.

Maximum individual (maximally exposed individual) - An individual of the general public whose locations and habits tend to maximize his radiation dose, resulting in a dose higher than that received by other individuals in the general population.

Milling - Stage of fuel production in which uranium ore is purified into a more concentrated form called yellowcake. 
Nuclide - A species of atom having a specific mass, atomic number, and nuclear energy state.

Operating capacity - (See capacity factor.)

Peak rod average burnup - The rod average burnup level of the peak rod in a fuel batch or reactor core.

Pellet-cladding interaction (PCI) - Interaction between the fuel pellet and cladding that results in cladding stresses and chemical reactions that may lead to cladding rupture.

Population dose - The dose equivalent received by the general population from radioactive materials. The unit is man-rem, or person-rem.

Precursor - A nuclide that precedes that nuclide in a decay chain; parent.

Pressurized water reactor (PWR) - A LWR in which heat is transferred from the core to a heat exchanger via water kept under high pressure, so that high temperatures can be maintained in the primary system without boiling the water. Steam to power the turbines is generated in the secondary circuit.

Quality factor (Q) - The factor by which the absorbed dose (rad or gray) is multiplied to obtain a quantity that expresses the effectiveness of the absorbed dose in causing biological damage on a common scale for all ionizing radiation. In practice, $Q$ is taken as unity for $x$ rays, gamma rays, and beta particles. (See dose equivalent.)

Radiation (ionizing) - Particles and electromagnetic energy emitted by nuclear transformations that are capable of producing ions when interacting with matter; gamma rays and alpha and beta particles are examples.

Radioactivity - (See activity.)

Radionuclide - Any nuclide that is radioactive.

Radwaste - Waste that contains radioactive materials.

Reference reactor year (RRY) - One year of operation of a model 1000-megawattelectrical (MWe) reactor that is assumed to be operating at its maximum capacity for one year with an on-stream plant factor of $80 \%$.

Release fraction - (See gap-release fraction.)

Reprocessing - Process in which some of the remaining unused uranium is extracted from used fuel to be used in the production of new fuel. This reduces the need for uranium ore. Reprocessing represents the closing of the fuel cycle. 
Rem - Unit of dose equivalent. The absorbed dose of ionizing radiation modified by the quality factor and sometimes other factors that result in the same biological effect as 1 rad of radiation; 1 rem $=1$ rad for $x$, gamma, or beta radiation. (See dose equivalent and quality factor.)

Rod average burnup - The burnup level of a fuel rod averaged (arithmetic mean) over its active fuel length.

Separative work unit (SWU) - A measure of work required to separate a quantity of isotopic mixture into two component parts, one having a higher percentage of concentration of the desired isotope and one having a lower percentage. The SWU is expressed in units of the kilogram $(\mathrm{kg})$.

Tonne $(t)$ - Unit of mass. Sometimes called metric ton (MT) = 1 megagram $(\mathrm{Mg})=1,000$ kilogram $(\mathrm{kg})=2,205$ pounds.

Transuranium nuclide (transuranic) - A nuclide having an atomic number greater than that of uranium, which is 92 ; usually characterized by having a long half-life and low or no gamma emissions.

Yellowcake - The final precipitation formed in the mining of uranium ores $\left(\mathrm{UO}_{2}\right)$. 



\section{EXECUTIVE SUMMARY}

This assessment has been performed in partial response to a petition for rulemaking to the U.S. Nuclear Regulatory Commission (NRC) requesting that regulations be amended to require preparation of an environmental impact statement on the environmental effects of the use of extended burnup fuel in the nation's light water commercial power reactors (LWRs), and it has been performed in view of the anticipated increase in applications for the use of this fuel. The overall findings of this assessment are that no significant adverse effects will be generated by increasing the present batch-average burnup level of $33 \mathrm{GWd} / \mathrm{t}$ uranium to $50 \mathrm{GWd} / \mathrm{t}$ or above, as long as the maximum rod average burnup level of any rod is no greater than $60 \mathrm{GWd} / \mathrm{t}$.

Extensive studies of extended burnup fuels have been conducted under the direction of the U.S. Department of Energy (DOE) and the Electric Power Research Institute (EPRI), with the participation of the fuel vendors nationwide and with the cooperation of several nuclear reactor utilities. These studies have shown that there is no loss in fuel integrity for rod average burnups reaching $60 \mathrm{GWd} / \mathrm{t}$, as long as power levels for the fuel rods remain normal. Activity inventory may increase for long-lived radionuclides of concern; however, for short-lived fission products, the inventories will essentially remain the same. Of the longer lived fission products of concern, only cesium-134, cesium-137, and strontium-90 increase much with burnup (by factors of 2.5, 1.9, and 1.8, respectively). Neutron emission rate from transuranium isotopes will increase with burnup by a factor of 5.6. Fuel cladding gap-release fractions for volatile fission products may increase by factors of two, but will remain below regulatory guide assumptions on noble gases and iodines at current power levels.

If leakage of radionuclides from a fuel element occurs during operation, the activity is expected to be removed by the plant cooling-water cleanup system. No change in the licensed technical specifications pertaining to allowed cooling-water activity concentrations would be necessary. Thus, with extended burnup, little or no increase in the release of radionuclides to the environment is expected during normal operation. Other parts of the fuel cycle would also not be adversely affected by changing to an extended burnup fuel utilization plan. The impacts on workers and the general population would actually be reduced because at higher burnups, outages for fuel changes will be less frequent, and fuel shipments to and from the reactor sites will be reduced, thus reducing exposure. Although the inventory of long-lived radionuclides in the spent fuel will increase, the amount of spent fuel removed from reactors each year will decrease. Table $S .1$ summarizes the impacts of normal operation.

Accidents that involve the damage or melting of the fuel in the reactor core and spent-fuel handling accidents were also reviewed. For accidents in which the core remains intact, the release would involve only volatile fission products, and no increases in impacts would occur, because the radionuclides contributing most to the dose are short lived and thus do not increase with burnup. For larger (severe) accidents in which an appreciable amount or all of the fuel has melted and been released from the containment system into the 
TABLE S.1. Summary of Changes in Radiological Impacts for Various Fuel-Cycle Activities with the Implementation of Extended Burnup Fue1

\begin{tabular}{|c|c|c|c|}
\hline Activity & $\%$ Change & Primary Contributors & Reference $(\mathrm{a})$ \\
\hline Mining & -5 & Rn \& daughters & Table 3-11 \\
\hline Milling & -5 & $\begin{array}{l}\text { Ra-226, Th-230, U \& } \\
\text { daughters }\end{array}$ & Table 3-13 \\
\hline Conversion & -5 & $\begin{array}{l}\text { U \& daughters, Ra-226, } \\
\text { Th-230 }\end{array}$ & Table 3-14 \\
\hline Enrichment & 1 & U \& daughters & Table 3-15 \\
\hline Fabrication & -45 & Th-234, U \& daughters & Table 3-16 \\
\hline Refueling & -45 & & \\
\hline $\begin{array}{l}\text { Normal reactor } \\
\text { operation }\end{array}$ & ${ }_{0}^{(b)}$ & $\begin{array}{l}\text { Cs, tritium, I-131, } \\
\mathrm{kr}, \mathrm{sr}-90, \mathrm{Xe}\end{array}$ & $\begin{array}{l}\text { Table } 3.1 \text { of } \\
\text { this report }\end{array}$ \\
\hline $\begin{array}{l}\text { Transportation: } \\
\text { Fresh fuel } \\
\text { Spent fuel } \\
\text { Solid wastes }\end{array}$ & $\begin{array}{r}-45 \\
-45 \\
20\end{array}$ & $\begin{array}{l}\text { U } \\
\text { Fission products } \\
\text { Corrosion, activation, } \\
\text { fission products }\end{array}$ & $\begin{array}{l}\text { Table } 4-3 \\
\text { Page } 4-4 \\
\text { Page } 4-19\end{array}$ \\
\hline Waste management & $\begin{array}{l}\text { See Table } \\
3.4\end{array}$ & & \\
\hline Reprocessing & -44 to -3 & $\begin{array}{l}\text { Tritium, C-14, Kr-85, U, } \\
\text { I-129, I-133, Ru-106, } \\
\text { Fission Products, } \\
\text { Transuranics }\end{array}$ & Table 3-24 \\
\hline
\end{tabular}

\footnotetext{
(a) Tables and pages referenced are from Mauro et al. 1985.

(b) There would be no change in the licensed technical specifications for cooling-water activity.
}

biosphere (Class 9) only a few fission products and the actinides will increase in inventory with increased burnup. The fission products would increase by no more than a factor of two, and the actinides by no more than a factor of six (of those contributing to the dose). However, since these actinides have very small release fractions and biotransfer factors, the risks associated with the actinides would be insignificant compared to those associated with fission products such as cesium-137 and strontium-90. Furthermore, the factors of increases in the radioactive sources are less than the uncertainty involved in determining the overall risk to the public. 
For the fuel-handling accident, only the noble gases and iodines escaping the damaged cladding are of significance in the assessment of dose impacts to the population. For a peak rod at a burnup level of $60 \mathrm{GWd} / t$, the release fractions only increase by a factor of three to four for these radionuclides; however, they remain below those assumed in Regulatory Guide 1.25, with the exception of iodine-131. Because the calculated iodine gap-release fraction is $20 \%$ greater for some high-power fuel designs than the Regulatory Guide 1.25 (NRC 1972) assumed value of 0.10 , the calculated thyroid doses with extended burnup fuel resulting from a fuel-handling accident could be $20 \%$ higher than estimated using the guide.

Spent-fuel transportation accidents were reviewed. Activity inventory may increase by an overall factor of about three for long-lived radionuclides of concern (assuming a 5-year cooling period) when changing to extended burnup fuel. However, this increase is offset by a decrease in the number of fueltransport trips required, such that the overall change would be a $50 \%$ increase in impact by changing to $60 \mathrm{GWd} / \mathrm{t}$ burnup.

The use of extended burnup fuel would reduce fuel requirements per unit of electricity. This translates directly into reduced requirements for the various materials and operations linked to fuel production (uranium mining, milling, conversion, separation, and fuel fabrication). The result of these reduced production requirements will be a significant reduction in cost, as well as a reduction in environmental impacts from fuel-cycle operations required to support one year of reactor operation.

Although the discharged fuel at extended burnup is thermally slightly hotter, has increased neutron emission, and has more long-lived nuclides per unit mass compared with fuel that has not undergone extended burnup, the volume of fuel discharged per unit time will be reduced; thus, although the waste contains a greater actinide and long-lived fission-product activity, there will be less of it. This ambiguous nature of the waste has an effect on all the back-end stages of the fuel cycle (at-reactor storage, transportation, and repository storage). The net result of these changes would be an increase in transportation shielding requirements, a reduction in the number of fuel shipments, smaller repository waste packages or increased spacing in the underground repository, and a reduction in future at-reactor storage requirements.

Sources used in this study indicate that a reduced volume of waste will result in a net reduction of at-reactor storage costs and transportation costs. However, estimates of the effects on repository storage costs range from a substantial increase to a substantial decrease, depending on repository building assumptions. Because of uncertainties regarding repository specifications at this time, these estimates only indicate the range of likely effects.

A summary of the cost savings resulting from the implementation of extended fuel burnup is presented in Table S.2. The Table shows the cost savings for different stages in the fuel cycle. The wide range given for some cost activities, most notably repository costs, reflects differences in estimates among various references. The total discounted cost savings resulting from the 
IABLE S.2. Summary of Estimated Discounted Cost Savings from Extended Fuel Burnup by Activity, 1985-2020

Fuel Cycle Stage/Activity

Front end of fuel cycle

Research and development

Fuel production and fuel management

Subtotal

Back end of fuel cycle

Development and evaluation

At-reactor storage

Transportation

Repository

Subtotal

TOTAL FUEL-CYCLE SAVINGS
Savings

(millions of $1985 \$$ )

\begin{tabular}{rrr} 
& & 0 \\
4 to & 78 \\
-666 & to & 94 \\
\hline-614 to & 214 \\
1,917 to 2,745
\end{tabular}

implementation of extended burnup for all reactors in current operation for the period 1985 to 2020 is estimated to be on the order of $\$ 2$ billion. Almost all of this amount comes from savings in the front end of the fuel cycle. Small cost savings are noted in at-reactor storage and transport of spent fuel. Sources disagreed as to the extent of effects of extended burnup on repository costs. One source estimated a cost increase in this area of from $\$ 390$ million to $\$ 670$ million (Weston 1985), whereas data from another source suggested a relatively modest decrease in repository costs of between $\$ 78 \mathrm{mil}$ lion and $\$ 94$ million (Dippold and Wampler 1984). Because there are a number of severe limitations in the source data, these estimates must be viewed with caution. 


\subsection{INTRODUCTION}

This study was conducted by Pacific Northwest Laboratory (PNL) for the U.S. Nuclear Regulatory Commission (NRC) in partial response to a petition regarding the use of extended burnup nuclear fuel in the nation's light water power reactors (LWRs) and in anticipation of an increase in applications for the use of this fuel. Topics addressed in this assessment include the physical effects of extended burnup on the fuels, the environmental effects during both normal operations and accident events, and the economic effects on the fuel cycle. This report also includes a glossary of technical terms used in the document and an appendix that provides activity inventories for various radionuclides at selected burnup levels.

\subsection{DISCUSSION OF THE PETITION}

A petition for rulemaking was submitted on March 6, 1980, by Ms. Catherine Quigg on behalf of Pollution and Environmental Problems, Inc. (Quigg 1980). The petitioner's primary concern was the potential for the proliferation of the use of extended burnup fuel by the nation's commercial nuclear power reactors. Another concern expressed by the petitioner was the U.S. Department of Energy's (DOE's) program with various fuel vendors to test higher burnup fuel assemblies in the cores of some selected commercial power reactors. These activities, according to the petitioner, "could cause significant and widespread long- and short-term effects on the human environment" (Quigg 1980). The DOE program has been discussed in detail in a study issued by the DOE (1980a): Environmental Assessment, DOE Program to Improve Uranium Utilization in Light Water Reactors.

The petitioner requested that the NRC amend its regulations to require preparation of a generic environmental impact statement (EIS) on the use of high burnup nuclear fuels in commercial LWRs (see Glossary). This assessment has been conducted in partial response to that petition to determine if a significant environmental impact would be caused by the widespread use of extended burnup fuel, thus necessitating the need for development of a generic EIS.

\subsection{EXPLANATION OF EXTENDED BURNUP FUEL}

Burnup is a measure of the energy generated by fuel in a nuclear reactor. Burnup, which at times is also called exposure, is measured in megawatt-days per metric ton (tonne) of uranium (MWd/MTU) or gigawatt-days per tonne of uranium $(G W d / t)$. In the literature, the term "megawatt-days per kilogram of uranium" (MWd/kg) is also found; $1 \mathrm{GWd} / \mathrm{t}=1 \mathrm{MWd} / \mathrm{kg}=1,000 \mathrm{MWd} / \mathrm{MTU}$. Currently, fuel burnups are around $31 \mathrm{GWd} / \mathrm{t}$ for boiling water reactors (BWRs) and $36 \mathrm{GWd} / \mathrm{t}$ for pressurized water reactors (PWRs), averaged (weighted mean) over the batch of fuel assemblies to be replaced in the core during a refueling outage (batch average) (see Glossary for definitions of terms). Under an experimental program sponsored by the DOE, fuel rods manufactured by the various vendors have been exposed to burnups as high as 45 to $60 \mathrm{GWd} / \mathrm{t}$ in a few participating reactors. The ultimate goal of this study is to determine the fuel behavior at peak rod burnups of $65 \mathrm{GWd} / \mathrm{t}$ (DOE 1980a, p. 2), which would correspond to a batch average of around $50 \mathrm{GWd} / \mathrm{t}$. 
The differences between "high" burnup fuel and "current" burnup fuel vary among fuel vendors. In general, high burnup fuel consists of higher uranium-235 enrichment (see Glossary) than current fuel. This usually results in higher fuel-rod power peaking in the core. The higher peaking is currently controlled by varying the enrichment radially and axially within the core and by using additional burnable poison material. Hardware design changes for extended burnup also vary from vendor to vendor, but some typical changes are larger fuel-rod plenums, smaller fuel-rod diameters, fuel-to-cladding (see Glossary) gap changes, and changes in tie-plate clearances from fuel rod to upper assembly.

\subsection{PROJECTED INDUSTRY USAGE OF EXTENDED BURNUP FUEL}

The nationwide aggregate environmental and economic effects of using extended burnup nuclear fuel depend on the amount of electricity generated by nuclear power and the proportion of that amount that is generated by extended burnup fuel. Projections of U.S. nuclear generating capacity (see Glossary), developed by the U.S. Department of Energy/Energy Information Administration (DOE/EIA), are given in Table 1.1. Note that the DOE/EIA has released several sets of projections. The ones shown here are the latest available and, therefore, will differ somewhat from those published earlier and from projections used by other sources referenced in this work. Table 1.1 presents four sets of projections reflecting alternative assumptions about future plant construction and other factors. This report adopts the middle case as best reflecting the most probable future generating capacity, since it represents capacity growth near the middle range of the DOE/EIA projections.

Three prospective extended burnup implementation schedules are presented here. The first, taken from Murphie and Lang (1982), is shown in Table 1.2. This schedule forecasts the rate of implementation in terms of the percentage of fuel supplied. According to this source, 55\% of all U.S. vendor-supplied

TABLE 1.1. Projections of U.S. Nuclear Generating Capacity (net GWe at year end)

\begin{tabular}{|c|c|c|c|c|}
\hline \multirow[b]{3}{*}{ Year } & \multirow{2}{*}{$\begin{array}{l}\text { With } \\
\text { No New }\end{array}$} & \multicolumn{2}{|c|}{ Including New } & Orders \\
\hline & & Low & Middle & $\overline{\mathrm{High}}$ \\
\hline & Orders & Case & Case & Case \\
\hline 1984 & 71 & 71 & 71 & 71 \\
\hline 1985 & 71 & 77 & 80 & 85 \\
\hline 1990 & 105 & 105 & 110 & 113 \\
\hline 1995 & 108 & 108 & 117 & 117 \\
\hline 2000 & 106 & 106 & 116 & 119 \\
\hline 2005 & 106 & 119 & 149 & 174 \\
\hline 2010 & 104 & 129 & 182 & 237 \\
\hline 2015 & 59 & 137 & 216 & 306 \\
\hline 2020 & 46 & 144 & 248 & 377 \\
\hline
\end{tabular}

Source: DOE/EIA 1985, p. 24 . 
TABLE 1.2. Projected Implementation Schedule

for Extended Burnup Fuel Use

\begin{tabular}{|c|c|}
\hline Year & $\begin{array}{l}\% \text { of Total } \\
\text { Fuel Supplied }\end{array}$ \\
\hline $\begin{array}{l}1981 \\
1985 \\
1990 \\
1995 \\
2000\end{array}$ & $\begin{array}{r}0 \\
11 \\
55 \\
80 \\
100\end{array}$ \\
\hline
\end{tabular}

Source: Murphie and Lang 1982.

fuel will be used for extended burnup fuel operation by 1990 , with $100 \%$ implementation by the year 2000 . This usage is reached by

a series of small $(3,000-5,000 \mathrm{MWd} / \mathrm{mt})$ [3 to $5 \mathrm{GWd} / \mathrm{t}$ ] incremental increases in burnup being introduced at several-year intervals, with nearly full deployment of each increment following 5 to 6 years after commercial introduction. The schedule is also based on a fairly aggressive research, development and demonstration program; any reduction in support would delay the implementation schedule. Commercial introduction and widespread availability at each increment in burnup are expected to closely follow technical demonstration [Murphie and Lang 1982, p. 7-63].

The average burnup of this fuel was not specified, but it can be expected to vary depending on the circumstances of the various utilities. However, Lang (1986) has recently stated that the DOE goals for burnup extension are $50 \mathrm{GWd} / \mathrm{t}$ (batch average) for PWRs and $45 \mathrm{GWd} / \mathrm{t}$ (batch average) for BWRs.

A second forecasted implementation schedule, developed by Franks and Geller (1986), is presented in Table 1.3. Shown in the table are alternate time patterns based on different assumed scenarios: 1) no change in current burnup levels, 2) no additional DOE-funded research on extended burnup, 3) likely implementation schedule consequent to additional DOE-funded research, and 4) maximum implementation rate schedule assuming DOE-funded research.

A third and more detailed set of forecasts of extended burnup implementation and the amount of spent fuel generated is found in Weston (1985). Table 1.4 presents expected aggregate average burnup levels for PWRs and BWRs, by year, for an implementation schedule in which utilities are assumed to introduce fuel designed for extended burnup as quickly as it becomes available. The discharge burnup levels (see Glossary) are assumed to reach $60 \mathrm{GWd} / \mathrm{t}$ in 2005 for PWR fuel and 45 GWd/t in 2000 for BWR fuel (Weston 1985, p. 2-1).

Table 1.5 shows two sets of forecasts for annual spent-fuel discharges. Both sets are consistent with the DOE/EIA middle-case projections of U.S. nuclear generating capacity. The first set shows the spent-fuel discharges 
TABLE 1.3. Alternate Forecasts of Batch Average Burnup Levels (GWd/t) by Reactor Type and Date of Fuel Loading, 1980-2020

\begin{tabular}{|c|c|c|c|c|c|c|c|c|}
\hline \multirow[b]{2}{*}{ Date } & \multicolumn{2}{|c|}{$\begin{array}{c}\text { Current } \\
\text { Burnup Levels }\end{array}$} & \multicolumn{2}{|c|}{$\begin{array}{l}\text { Without New } \\
\text { R\&D }\end{array}$} & \multicolumn{2}{|c|}{$\begin{array}{l}\text { With New } \\
\text { R\&D }\end{array}$} & \multicolumn{2}{|c|}{$\begin{array}{c}\text { Maximum } \\
\text { Implementation }\end{array}$} \\
\hline & BWR & PWR & BWR & PWR & BWR & PWR & BWR & PWR \\
\hline $\begin{array}{c}\text { Before } \\
1 / 1 / 1980\end{array}$ & 28.5 & 33 & 28.5 & 33 & 28.5 & 33 & 28.5 & 33 \\
\hline $\begin{array}{c}\text { Before } \\
1 / 1 / 1985\end{array}$ & 28.5 & 33 & 31 & 39 & 31 & 39 & $32-33$ & 39 \\
\hline $\begin{array}{l}\text { Before } \\
1 / 1 / 1990\end{array}$ & 28.5 & 33 & 35 & 40 & 38 & 45 & $38-40$ & 45 \\
\hline $\begin{array}{c}\text { Before } \\
1 / 1 / 1995\end{array}$ & 28.5 & 33 & 38 & 45 & 40 & 50 & $40-42$ & 50 \\
\hline $\begin{array}{l}\text { After } \\
1 / 1 / 2000\end{array}$ & 28.5 & 33 & 38 & 50 & 43 & 55 & $42-45$ & 55 \\
\hline
\end{tabular}

Source: Franks and Geller 1986, Tables 3-3 and 4-2.

TABLE 1.4. Aggregate Average Burnup of Spent Fue 1 at Discharge by Fuel Type and Year of Discharge from Reactor

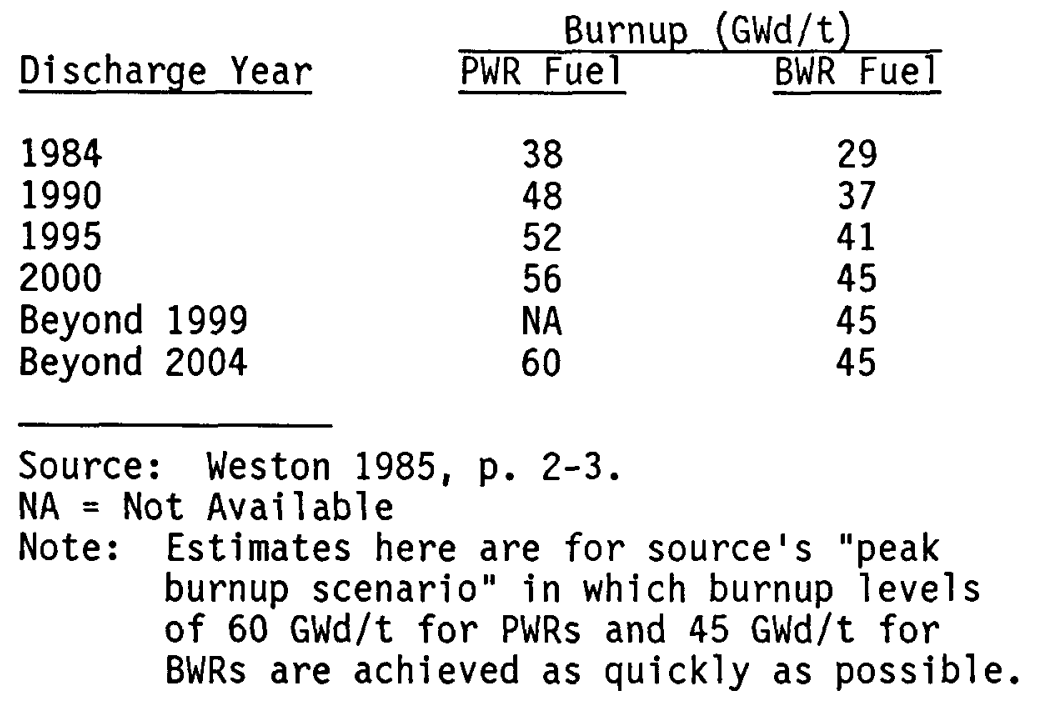


TABLE 1.5. Forecasts of Spent-Fuel Discharges (tonne of uranium) and

Burnup Levels by Implementation Schedule and Year, 1985-2020

\begin{tabular}{|c|c|c|c|}
\hline Year & $\begin{array}{c}\text { Discharge Without } \\
\text { Extended Burnup } \\
(\mathrm{t})\end{array}$ & $\begin{array}{l}\text { With Rapid Ir } \\
\text { of Exten } \\
\text { Burnup Level } \\
\quad(\mathrm{GWd} / \mathrm{t}) \\
\end{array}$ & $\begin{array}{l}\text { lementatior } \\
\text { B Burnup } \\
\text { Discharge } \\
(t)\end{array}$ \\
\hline $\begin{array}{l}1985 \\
1986 \\
1987 \\
1988 \\
1989 \\
1990 \\
1995 \\
2000 \\
2005 \\
2010 \\
2015 \\
2020\end{array}$ & $\begin{array}{l}1,250 \\
1,414 \\
1,650 \\
1,960 \\
2,110 \\
2,333 \\
2,733 \\
3,015 \\
3,443 \\
4,501 \\
4,294 \\
4,882\end{array}$ & $\begin{array}{l}39.7 \\
41.0 \\
43.0 \\
44.0 \\
46.4 \\
48.0 \\
52.0 \\
56.0 \\
60.0 \\
60.0 \\
60.0 \\
60.0\end{array}$ & $\begin{array}{r}900 \\
1,021 \\
1,187 \\
1,447 \\
1,553 \\
1,653 \\
1,527 \\
1,510 \\
1,873 \\
3,197 \\
2,632 \\
2,513\end{array}$ \\
\hline
\end{tabular}

Source: Weston 1985, Table 2-5.

Note: Data are consistent with DOE/EIA middle case

forecast. Burnup level (GWd/t) is the national

average burnup at the time of discharge for

PWR fuel.

with no extended burnup. The second set of forecasts corresponds to the scenario in which extended burnup is adopted as quickly as possible. The columns showing fuel discharges indicate clearly the decrease in the amount of fuel discharged as a result of the implementation of extended burnup.

Table 1.6 presents a rough comparison of the three sets of PWR burnup level forecasts. Several aspects of this table require explanation. The Murphie and Lang forecasts were converted to burnup levels based on Lang's (1986) most recent estimate of PWR goal (batch average) burnups of $50 \mathrm{GWd} / \mathrm{t}$ from the base level of $33 \mathrm{GWd} / \mathrm{t}$. For example, the 1995 forecast of $80 \%$ of fuel supplied being extended burnup fuel was interpreted to mean that average burnups had increased $80 \%$ of the way from $33 \mathrm{GWd} / \mathrm{t}$ to $50 \mathrm{GWd} / \mathrm{t}$. This interpolation is done to compare the different forecasts of burnup levels on a consistent basis. The schedule shown for the Franks and Geller data is consistent with both the likely and maximum implementation rates. Slight liberties have also been taken with the reported dates. For example, the 1984 weston figure is reported for 1985.

Generally, the implementation schedules are in close agreement. Murphie and Lang show full conversion to a $50 \mathrm{GWd} / \mathrm{t}$ burnup level by the year 2000, while the Franks and Geller schedule reaches $55 \mathrm{GWd} / \mathrm{t}$. By the year 2005, Weston projects a peak burnup level of $60 \mathrm{GWd} / \mathrm{t}$. There are differences in these forecasts other than the obvious differences in burnup level. For 
TABLE 1.6. Comparison of PWR Burnup Level (GWd/t)

Forecasts by Source and Year, 1980-2005

\begin{tabular}{|c|c|c|c|}
\hline Year & $\begin{array}{c}\text { Murphie } \\
\text { and Lang } \\
1982 \\
\end{array}$ & $\begin{array}{c}\text { Franks and } \\
\text { Geller } \\
1986 \\
\end{array}$ & $\begin{array}{l}\text { Roy F. } \\
\text { Weston } \\
1985 \\
\end{array}$ \\
\hline $\begin{array}{l}1980 \\
1985 \\
1990 \\
1995 \\
2000 \\
2005\end{array}$ & $\begin{array}{l}33 \\
35 \\
42 \\
47 \\
50 \\
50\end{array}$ & $\begin{array}{l}33 \\
39 \\
45 \\
50 \\
55 \\
55\end{array}$ & $\begin{array}{l}33 \\
38 \\
48 \\
52 \\
56 \\
60\end{array}$ \\
\hline
\end{tabular}

(a) Forecast actually given for 1984 by Weston (1985).

example, the Weston forecasts are dated by year of fuel discharge, whereas the Franks and Geller forecasts are dated by year of reactor loading. Consequently, the Franks and Geller forecasts differ from the Weston forecasts by 5 years because it takes approximately that length of time from fuel loading to discharge for these burnups to be achieved in commercial power reactors. The Murphie and Lang forecasts do not state whether they are based on the year of reactor loading or on discharge burnup; however, it is assumed that they are based on discharge burnups because their forecast closely matches the observed discharge burnups for 1985.

\subsection{U.S. LICENSING EXPERIENCE OF REACTORS USING EXTENDED BURNUP FUEL}

Fuel has been supplied to reactors in the U.S. by five vendors: Babcock and Wilcox Co.; Combustion Engineering, Inc.; Exxon Nuclear Co., Inc.; General Electric Co.; and Westinghouse Electric Corp. These vendors have submitted extended burnup topical reports to the NRC for review and approval. The reports summarize their hardware design criteria, evaluation methods, and supporting data used for evaluating their designs. These reports have been reviewed and approved by the NRC (Berkow 1985; Butcher 1985; Rossi 1986; and Thomas 1985c,d) for their use in support of specific fuel design and plant applications for operation at extended burnup levels. Consequently, these approvals have not been for specific fuel designs nor for specific plants for operation at extended burnup levels. Specific fuel design and plant submittals for extended burnup operation will be reviewed and approved by the NRC based on their individual merits.

Two fuel vendors that manufacture BWR fuel have recently submitted new designs for fuel elements that would allow batch average burnups of between 40 and $45 \mathrm{GWd} / \mathrm{t}$. To economically achieve batch average burnups of greater than $50 \mathrm{GWd} / \mathrm{t}$ in both BWRs and PWRs, fuel enrichments need to be increased to the extent that significant fuel design changes will have to be implemented. Consequently, for the foreseeable future (i.e., within the next 10 years), it is not likely that batch average burnups will exceed $50 \mathrm{GWd} / \mathrm{t}$. All vendor 
and utility submittals to the NRC and their NRC approvals have been for batch average burnups of less than $50 \mathrm{GWd} / \mathrm{t}$.

Typical fuel reload orders for today's BWRs and PWRs have warranties for batch average burnups of about $31 \mathrm{GWd} / \mathrm{t}$ and $36 \mathrm{GWd} / \mathrm{t}$, respectively (Nuclear Fuel 1984). Studies, based on economics, indicate that present optimum extended burnups (discharge batch averages) for a 12-month cycle are typically about $45 \mathrm{GWd} / \mathrm{t}$ and $50 \mathrm{GWd} / \mathrm{t}$ for BWRs and PWRs, respectively, and about $10 \%$ higher for an 18-month cycle (Lang 1982a). It should be noted that optimum burnups based on economics can and most likely will change because the studies are dependent on front end and back end fuel-cycle costs that fluctuate. Economic studies have also been made of 24-month cycles (Rosenstein et al. 1986). The Electric Power Research Institute (EPRI) anticipates that fuel assemblies designed for improved extended burnup performance will not be available for full reloads until the late 1980s, and that burnup levels will gradually increase by 1 to $2 \mathrm{GWd} / \mathrm{t}$ per year (Franklin 1982).

Projected benefits to the LWR fuel cycle from extended burnup are discussed by Murphie and Lang (1982) and Lang (1982b). Extended burnup, in combination with low-leakage fuel management (see Glossary) techniques, will benefit the nuclear fuel cycle by reducing the generation of spent fuel, the requirements for uranium resources, the requirements for separative work (see Glossary), and the costs of the fuel cycle. The DOE sponsored the preparation of a report (Matzie 1981) that describes the licensing assessment of PWR extended burnup fuel cycles. The effects of DOE-sponsored development on fuel cycles are described by Lang (1986).

\subsection{FUEL OPERATING EXPERIENCE AT EXTENDED BURNUP}

The NRC publishes a series of annual reports that provide descriptions of fuel performance in domestic commercial nuclear power plants. The seventh report (Bailey and Dunenfeld 1986) covers fuel performance in calendar year 1984. One of the subjects discussed in the reports is high burnup fuel experience. Extended burnup demonstrations sponsored by EPRI were completed in 1983 and 1984, and the results are described in EPRI 1985. Information from these and other reports is discussed below.

In testimony given at hearings conducted on March 16 and 17, 1982, by the subcommittee on Energy Research and Production (Congressional Information Bureau 1982), the DOE indicated that fuel from each of the five U.S. fuel vendors, equivalent to 22 fuel assemblies, had been irradiated in seven commercial LWRs and that selected assemblies achieved burnups up to $47 \mathrm{GWd} / \mathrm{t}$. Since that time, experience with high burnup fuel has increased significantly (Bailey and Dunenfeld 1986).

The terms "fuel assembly" and "fuel bundle" are used interchangeably in the nuclear industry, although generally the former term is associated with fuel for PWRs and the latter with fuel for BWRs. A BWR fuel assembly consists of a fuel bundle and open-ended channel that encloses the bundle. The square array of rods making up a BWR fuel bundle is typically $7 \times 7,8 \times 8$, or $9 \times 9$. The array of rods in a PWR fuel assembly is typically $14 \times 14,15 \times 15,16 \times 16$, 
or $17 \times 17$. Figures 1.1 and 1.2 show typical BWR and PWR fuel assemblies respectively.

Over 10,000 BWR fuel bundles have attained burnups greater than $25 \mathrm{GWd} / \mathrm{t}$. Over 6,000 BWR fuel rods have reached batch average exposures of $36 \mathrm{GWd} / \mathrm{t}$, and over 350 have reached rod average exposures of 40 to $42 \mathrm{GWd} / \mathrm{t}$. BWR fuel has attained peak bundle exposures of $45.6 \mathrm{GWd} / \mathrm{t}$ and peak pellet exposures of approximately $60 \mathrm{GWd} / \mathrm{t}$ (the peak pellet exposure achieved in $8 \times 8$ fuel bundles is $58.1 \mathrm{GWd} / \mathrm{t}$ ) (Bailey and Dunenfeld 1986; Baily et al. 1985: Charnley 1985) Over 500,000 BWR fuel rods have reached peak pellet exposures greater than $30 \mathrm{GWd} / \mathrm{t}$.

At least 798 PWR fuel assemblies have achieved burnups of $36 \mathrm{GWd} / \mathrm{t}$ or higher. Of those 798 PWR assemblies, 84 have reached $40 \mathrm{GWd} / \mathrm{t}$ or higher. of the 84 assemblies, six have reached $48 \mathrm{GWd} / \mathrm{t}$ or higher, and four of the six assemblies have reached $55 \mathrm{GWd} / \mathrm{t}$ or higher. At least 163,028 PWR fuel rods

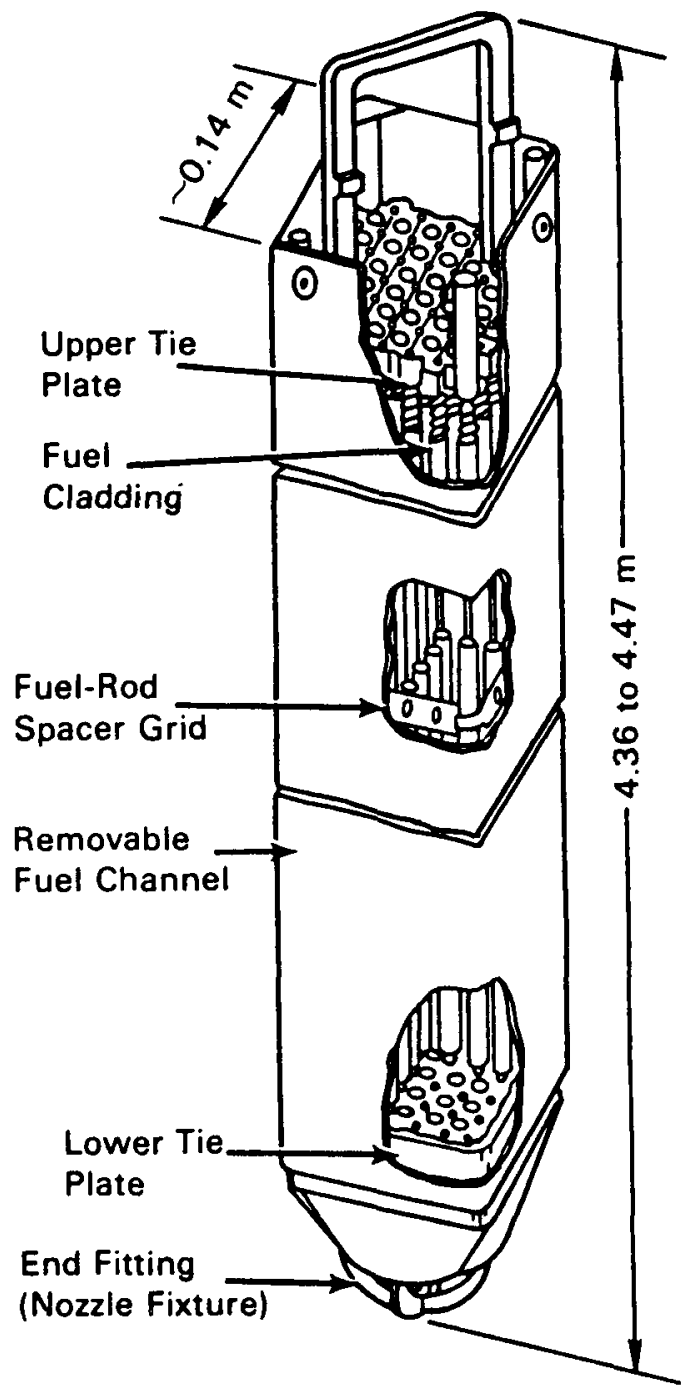

FIGURE 1.1. Example of a BWR Fuel Assembly 


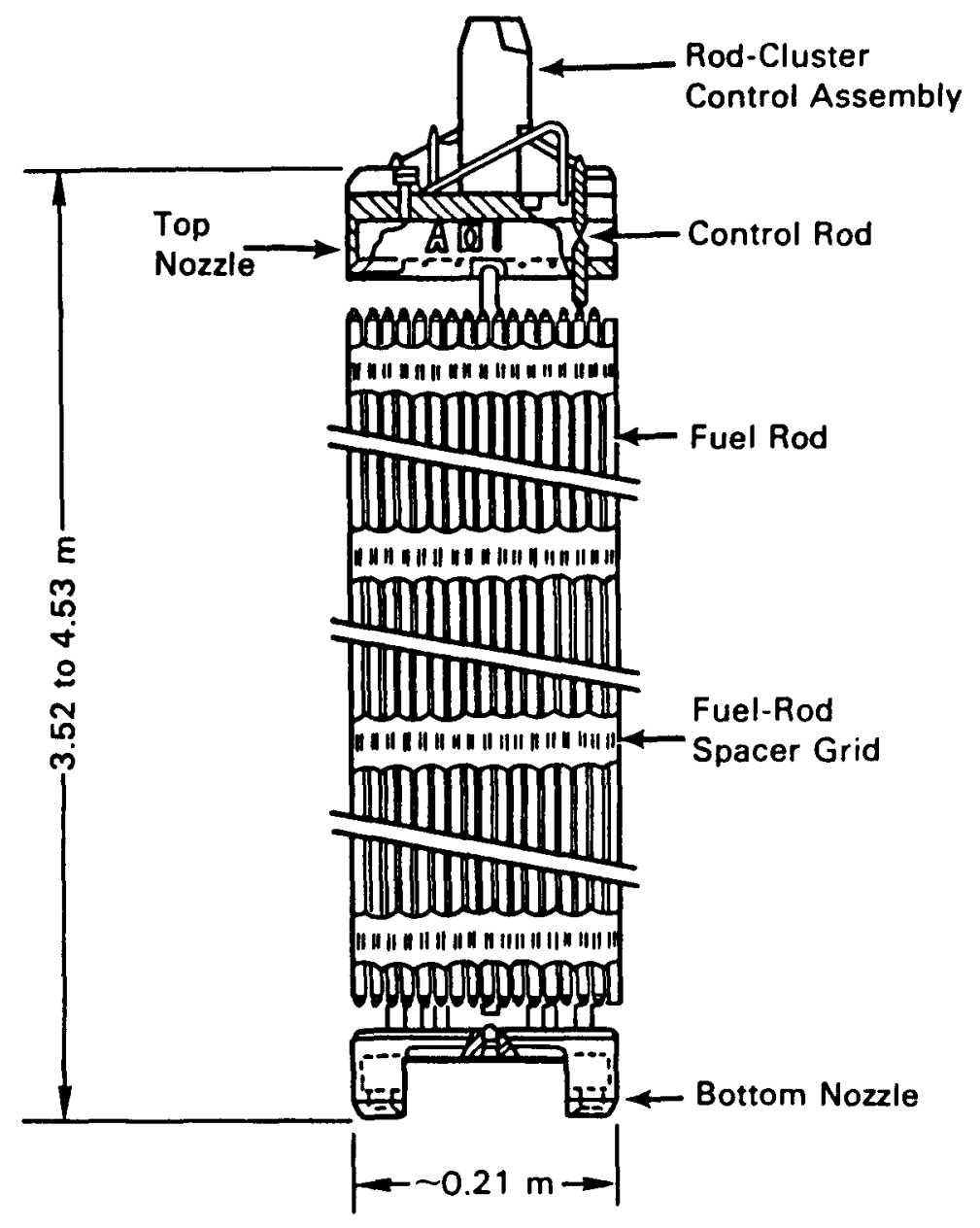

FIGURE 1.2. Example of a PWR Fuel Assembly

have attained burnups of $36 \mathrm{GWd} / \mathrm{t}$ or higher, with 16,142 of the PWR fuel rods reaching $40 \mathrm{GWd} / \mathrm{t}$ or higher. At least $1,200 \mathrm{PWR}$ fuel rods have reached $48 \mathrm{GWd} / \mathrm{t}$ or higher, and of those, 816 have attained burnups of $52 \mathrm{GWd} / \mathrm{t}$ or higher. Four PWR fuel assemblies achieved burnups of approximately $55 \mathrm{GWd} / \mathrm{t}$. Leak testing (sipping) data confirmed that the assemblies were leak-tight, and examinations did not disclose any characteristics that were adverse to fuel performance (EPRI 1983). Results from the DOE-sponsored examination of Westinghouse fuel rods, which were irradiated in the CEN BR-3 reactor to peak pellet burnups of $74 \mathrm{GWd} / \mathrm{t}$ and rod average burnups up to $61.5 \mathrm{GWd} / \mathrm{t}$, indicate that the fuel rods are leak-tight and exhibit no unusual performance features (Roberts 1982).

The experience through early 1982 suggests that no sudden or unexpected change in performance occurs in progressing to extended burnups (Roberts 1982). Secondly, no fuel failures solely attributable to the lifetime of the fuel in 
the reactor have been observed. Thirdly, performance of the fuel is more sensitive to power (i.e., linear heat generation rate) and operating temperatures of the cladding than to 1 ffetime in the reactor. General Electric has not experienced a single BWR rod failure that can be related to a high burnup condition (Baily et al. 1985). A recent report (EPRI 1985) states that research on fuel properties at burnups up to $55 \mathrm{GWd} / \mathrm{t}$ has shown that no technical limitations prevent such increases (from PWR burnups of $33 \mathrm{GWd} / \mathrm{t}$ ). Standard vendor product line PWR fuel has been irradiated to burnups in excess of $55 \mathrm{GWd} / \mathrm{t}$ with no reported indication that burnup limits of such fuel have been reached (Andrews et al. 1985). Babcock \& Wilcox observed a loss of cladding ductility in one Oconee (PWR) fuel assembly that had attained a measured burnup of $50.2 \mathrm{GWd} / \mathrm{t}$ (NEI 1985, Pyecha et al. 1985). The cladding ductility loss occurred during the last ( $\mathrm{fifth}$ ) cycle of irradiation. However, the ductility was still found to be acceptable at these burnup levels based on the $1 \%$ ductility criteria specified in the NRC Standard Review Plan (NRC 1981).

The goal for DOE and the nuclear industry is to achieve batch average burnups of $45 \mathrm{GWd} / \mathrm{t}$ for BWRs and $50 \mathrm{GWd} / \mathrm{t}$ for PWRs (Lang 1986). These batch average burnups correspond to peak rod average burnups (see Glossary) of 50 to $55 \mathrm{GWd} / \mathrm{t}$ for BWRs and 55 to $60 \mathrm{GWd} / \mathrm{t}$ for PWRs. In support of this goal, the DOE has sponsored several irradiation programs that have achieved assembly average burnups up to $46 \mathrm{GWd} / \mathrm{t}$ for BWRs and $55 \mathrm{GWd} / \mathrm{t}$ for PWRs (Lang 1986). Average burnups for the peak rod in these assemblies were $49 \mathrm{GWd} / \mathrm{t}$ and $62 \mathrm{GWd} / \mathrm{t}$, respectively. These irradiations, at extended burnup levels, have been performed without fuel failures and with satisfactory performance, as verified by both nondestructive poolside and destructive hot cell examination of the fuel after irradiation (Lang 1986).

The DOE- and EPRI-sponsored programs with the fuel vendors and utilities have resulted in both BWR and PWR fuel rods being irradiated to rod average burnups between 40 and $62 \mathrm{GWd} / \mathrm{t}$. These rods have been subjected to extensive nondestructive and destructive tests to determine their relative performance at extended burnups. For example, those rods that have experienced the highest burnups (around $62 \mathrm{GWd} / \mathrm{t}$ rod average) were nondestructively examined visually for surface anomalies and dimensional changes (fuel-rod diameters and lengths). Also, leak testing, gamma activity scanning, eddy-current testing for cladding anomalies, and waterside corrosion measurements were performed. The destructive examinations of fuel rods have included puncturing to determine the amount of fission gas release, fuel and cladding metallography, measurement of fuelcladding interaction, cladding-burst tests for ductility, and scanning electron microscopy to characterize the cladding inside and outside surfaces. In summary, government and industry irradiation programs have provided an indepth data base of fuel performance experience at extended burnups. 


\subsection{PHYSICAL EFFECTS}

This chapter contains a discussion of the potential physical effects of extended burnup on the fuel and the fuel assembly and a discussion of fissionproduct release from high burnup fuel.

\subsection{PHYSICAL EFFECTS ON FUEL AT EXTENDED BURNUP}

Potential physical effects of extended burnup on the fuel assembly and its components are presented in Table 2.1 as fuel performance considerations (Roberts 1982). (See Figures 1.1 and 1.2 for examples of fuel assemblies, and Figure 2.1 for an example of a fuel rod.) Included in Table 2.1 are the potential physical effects on the fuel pellets, the release of fission-product gases from the fuel, the fuel cladding, the fuel rod, the bowing of the fuel rod, the guide tubes for control rods, and the spacer grids. Each of these fuel performance considerations is discussed briefly below in relation to extended burnup operation.

Fuel-pellet swelling is a result of solid and gaseous fission-product production in the fuel and, thus, increases with fuel burnup. This phenomenon is modeled in each fuel vendor's fuel performance code and is accounted for in design and safety analyses of extended burnup operation.

The rate of fission-gas release from the fuel increases at extended burnup levels, which results in higher internal fuel-rod pressures. This phenomenon is also modeled in each fuel vendor's fuel performance code.

The rate of cladding corrosion (waterside) also increases for some plant and fuel designs at extended burnup levels. This leads to a reduction in cladding wall thickness. This phenomenon is also modeled in each fuel vendor's fuel performance code.

Cladding hydriding is a reaction product of cladding oxidation (corrosion) and results in a reduction in cladding ductility; however, for normal operating conditions, cladding corrosion becomes a problem before hydriding significantly reduces cladding ductility. Cladding ductility has been examined at extended burnup levels to ensure that it is consistent with the strain limits in the NRC Standard Review Plan (NRC 1981).

Cladding diametral creep (change in cladding diameter because of creep) is induced by cladding stresses that are generally compressive at moderate burnups; i.e., less than 25 to $30 \mathrm{GWd} / \mathrm{t}$, which changes to a net tensile stress at extended burnups (greater than $35 \mathrm{GWd} / \mathrm{t}$ for commercial fuel rods), resulting in an outward cladding creep. The tensile stress at extended burnups generally results from fuel swelling; however, significant power increases at lower burnup can induce plastic deformation and creep as a result of fuel thermal expansion. The NRC currently requires internal rod pressures to remain at sufficiently low levels to prevent a net outward creep of the cladding because of this mechanism. This prevents the fuel-cladding gap from opening up at extended burnups. The NRC Standard Review Plan (NRC 1981) conservatively bounds this situation by 
TABLE 2.1. Fuel Assembly Performance Considerations

\begin{tabular}{|c|c|c|}
\hline Item & Consideration & Design/Performance Impact \\
\hline Pellet & Swelling & $\begin{array}{l}\text { Pellet swelling increases with burnup. } \\
\text { With cladding contact, this can } \\
\text { result in pellet-to-cladding bonding } \\
\text { and cladding tensile strain. }\end{array}$ \\
\hline Fission gas & $\begin{array}{l}\text { Rod internal } \\
\text { pressure }\end{array}$ & $\begin{array}{l}\text { Fission-gas release increases with } \\
\text { increasing burnup. This is accept- } \\
\text { able provided that the internal rod } \\
\text { pressure criteria are not exceeded. }\end{array}$ \\
\hline \multirow[t]{5}{*}{ Cladding } & Corrosion/oxidation & $\begin{array}{l}\text { Increases in accelerating manner } \\
\text { with increase in burnup because of } \\
\text { adverse effect on cladding } \\
\text { temperature. }\end{array}$ \\
\hline & Hydriding & of less concern than oxidation. \\
\hline & Creep & $\begin{array}{l}\text { At high burnups, cladding could be } \\
\text { in tensile creep as a result of } \\
\text { fuel swelling and higher fission- } \\
\text { gas pressure. }\end{array}$ \\
\hline & Growth & $\begin{array}{l}\text { Cladding increases in length with } \\
\text { increasing burnup. Clearance } \\
\text { required to prevent rod interference } \\
\text { with structural components. }\end{array}$ \\
\hline & Ductility & $\begin{array}{l}\text { Ductility decreases and yield stress } \\
\text { increases with increasing fast neu- } \\
\text { tron fluence. However, most property } \\
\text { changes occur very early during } \\
\text { irradiation, and the incremental } \\
\text { effect of higher burnups is not a } \\
\text { major concern. }\end{array}$ \\
\hline Fuel rod & Flattening & $\begin{array}{l}\text { Avoidance of rod flattening is a } \\
\text { licensing requirement. Adequate } \\
\text { prepressurization levels in fabri- } \\
\text { cation must be ensured. }\end{array}$ \\
\hline Fuel-rod bow & Impact $\mathrm{DNB}^{(\mathrm{a})}$ & $\begin{array}{l}\text { This has an impact mainly during } \\
\text { the second cycle of operation. For } \\
\text { current fuel designs, rod bow is } \\
\text { much reduced in frequency, magnitude, } \\
\text { and potential impact on DNB margins. }\end{array}$ \\
\hline
\end{tabular}


TABLE 2.1. (Contd)

\begin{tabular}{|c|c|c|}
\hline Item & Consideration & Design/Performance Impact \\
\hline \multirow[t]{3}{*}{$\begin{array}{l}\text { Fuel assembly } \\
\text { guide tubes }\end{array}$} & $\begin{array}{l}\text { Corrosion } \\
\quad \text { (hydriding) }\end{array}$ & $\begin{array}{l}\text { The fuel assembly Zircaloy guide } \\
\text { tubes operate at lower temperature } \\
\text { and with no heat flux compared to } \\
\text { fuel rod tubes. Consequently, cor- } \\
\text { rosion (oxidation) is not a major } \\
\text { concern even though it is two sided. } \\
\text { However, hydriding and subsequent } \\
\text { loss of ambient ductility are con- } \\
\text { siderations, because hydrogen uptake } \\
\text { is occurring through both surfaces. }\end{array}$ \\
\hline & Growth & $\begin{array}{l}\text { Growth of the guide thimbles (overall } \\
\text { assembly growth) occurs during irradi- } \\
\text { ation, but is quite small. Higher } \\
\text { burnups could cause increased deflec- } \\
\text { tion of the fuel assembly holddown } \\
\text { spring. }\end{array}$ \\
\hline & Wear & $\begin{array}{l}\text { Wear of the guide thimble caused by } \\
\text { vibration of control-rod clusters } \\
\text { engaged in the fuel assembly has } \\
\text { been previously observed. This is } \\
\text { not burnup consideration per se. }\end{array}$ \\
\hline \multirow[t]{3}{*}{ Grid cell } & Stress relation & $\begin{array}{l}\text { The fuel rods are held in position } \\
\text { by the grid spring forces. Relaxa- } \\
\text { tion of these forces may result in } \\
\text { vibration of the fuel rods and } \\
\text { fretting wear in the cladding at } \\
\text { the point of realized spring contact. }\end{array}$ \\
\hline & Hydriding & $\begin{array}{l}\text { For Zircaloy springs, embrittlement } \\
\text { from hydrogen uptake is an additional } \\
\text { consideration for high burnup fuel. }\end{array}$ \\
\hline & Growth & $\begin{array}{l}\text { For Zircaloy grid straps, growth } \\
\text { will occur under irradiation. }\end{array}$ \\
\hline
\end{tabular}

Source: Roberts 1982.

(a) $D N B=$ departure from nucleate bolling. 


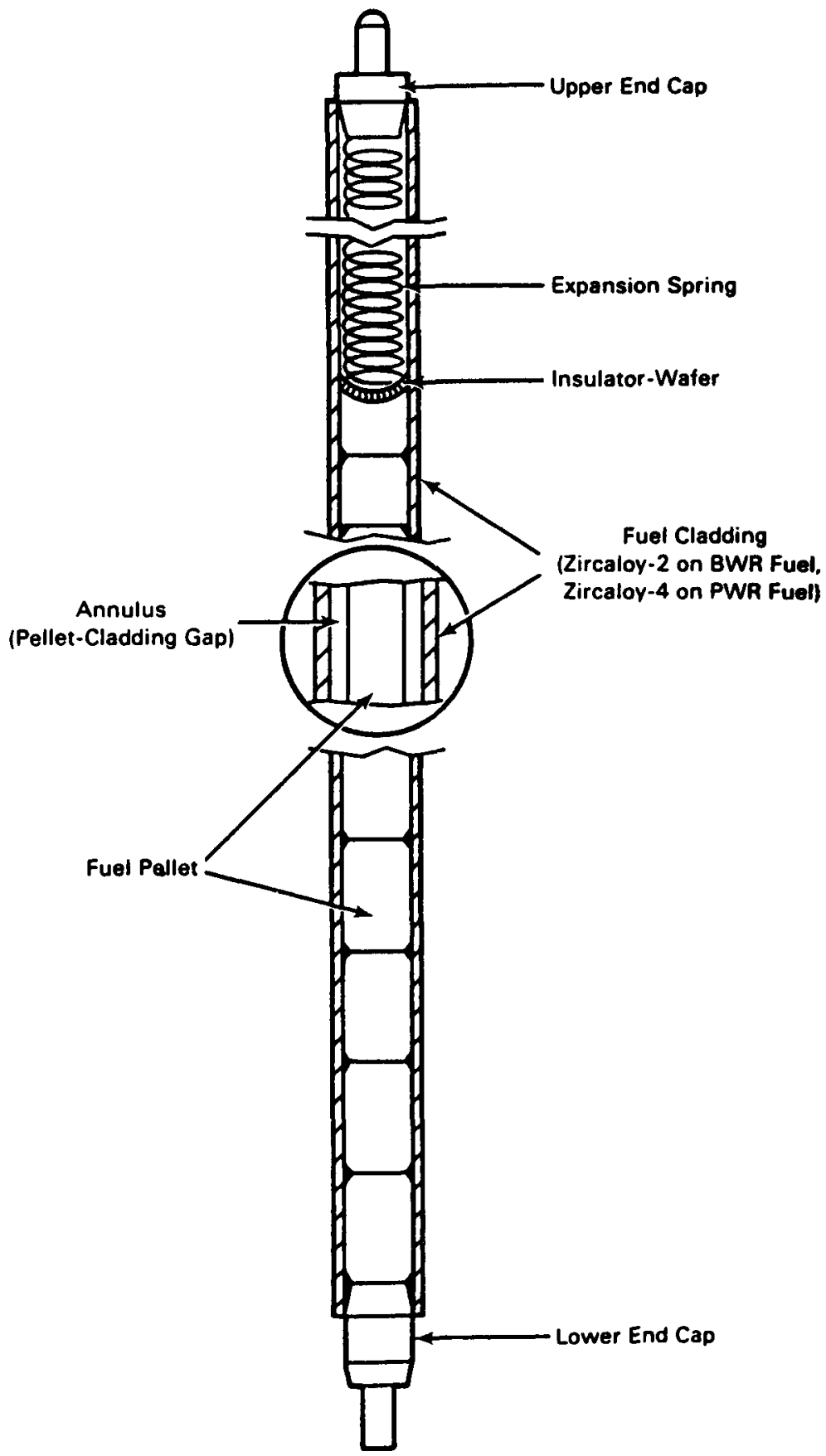

FIGURE 2.1. Cross Section of a Uranium Oxide Fuel Rod for a Commercial Light Water Power Reactor

limiting rod pressures to below primary system pressure. Cladding diametral creep is currently modeled by each fuel vendor in their fuel performance codes and other analytical approaches (e.g., in evaluating cladding flattening). 
Cladding and guide tube axial growth is a result of irradiation damage and creep, which increases with burnup. If the amount of growth is not properly accounted for in the fuel rod and assembly design, fuel-rod or assembly bowing can result due to interference between the fuel rod and assembly structural components or between the assembly and reactor components. This phenomena is modeled by the fuel vendors with analytical methods based on axial growth data from fuel rods and assemblies.

Cladding ductility decreases and yield stress increases with increasing neutron fluence. The ductility at the extended burnup levels anticipated and approved generically by NRC have been found to be within the strain limits suggested in the NRC Standard Review Plan (NRC 1981).

Fuel-rod flattening is a result of axial gap formation in the fuel column followed by cladding creep collapse into this gap. Cladding creep occurs when primary system pressures are greater than internal rod pressures. This phenomenon is modeled by the fuel vendors with analytical methods and, thus, is accounted for in design safety analysis of extended burnup operation.

Fuel-rod bow is caused by an azimuthal variation in the irradiation and thermal creep of the rod. If rod bow is sufficient to allow rods to come in close contact with each other during irradiation, a departure from nucleate boiling (DNB) and rod failure can result if rod powers are sufficiently high. Current fuel designs limit the extent of rod bow, and data indicate that rod bow saturates (i.e., it does not increase) at extended burnups. In addition, the lower power levels at extended burnups for current designs preclude the likelihood of a reduction in DNB margins.

Assembly guide-tube corrosion is not as significant a problem as is the case for the fuel cladding because temperatures are lower. The guide-tubes have performed without problems or a significant degradation in ductility in several assemblies irradiated to extended burnups.

Assembly guide-tube wear is due to coolant flow induced vibrations between the control rod ends and the inner wall of the guide tubes. Guide-tube wear has been observed in some of the older fuel designs in specific plants, however, it appears to have been eliminated in current designs.

The relaxation of grid spring forces is due to irradiation and thermal creep, which can result in fuel rod vibration and fretting wear of the cladding. This problem has been observed in older designs: However, it has not been observed in any of the extended burnup irradiations of current designs.

The embrittlement of grid springs has not been observed in any of the fuel assemblies irradiated to extended burnups to date. Also, no problems have been observed in any of the extended burnup irradiations due to grid-strap growth.

Each of the above fuel performance considerations, along with those provided in the NRC Standard Review Plan, have been examined and addressed by the NRC in their review (Berkow 1985; Butcher 1985; Rossi 1986; Thomas 1985c,d) of each fuel vendor's topical reports on extended burnups (Babcock \& Wilcox 1982; Exxon 1982; Combustion Engineering 1984; General Electric 1982; and 
Westinghouse 1982). These reviews have concluded that the computer codes and analysis methods used by each fuel vendor for evaluating the physical effects of fuel performance have been adequately verified against data up to a particular extended burnup limit. This limit is directly related to the burnup level of the data and is deemed proprietary by many of the fuel vendors. These data and analysis methods along with design limits will be used by each vendor to show that their particular fuel designs can operate safely without fuel damage up to a limiting burnup level.

The NRC reviews have identified some performance considerations that need additional attention because of either 1) lack of appropriate data at extended burnups, or 2) design limits being approached at extended burnups. Those performance considerations that need additional data are cladding (fuel rod) and guide-tube growth at extended burnup. In addition, guide tubes (wall thickness) need to be examined for particular designs at extended burnups. The fuel-rod cladding and guide-tube growth are of concern because they can cause interference with assembly and reactor structural components resulting in fuel-rod and assembly bowing. The guide-tube wear appears to be plant and design-dependent and results from flow-induced vibrations between the control rod ends and the inner wall of the guide tubes. Recent design changes are believed to have eliminated this problem for those susceptible designs; however, data are needed to confirm this at extended burnup. The lack of data for these fuel performance considerations is being addressed by each fuel vendor through experimental and lead test assembly irradiations before the operation of commercial fuel batches at extended burnup.

The performance consideration that is closest to the design limits of some fuel designs at extended burnup is the internal rod pressure for the peak licensed rod in a fuel batch. The increased rod pressure results from the increased fission-gas release from the fuel at extended burnup. Each vendor has stated that design and safety analyses will be submitted to NRC for each individual fuel design intended for extended burnup operation to demonstrate that they meet all design and safety criteria. The maximum burnup achievable for each design will vary; however, the maximum extended burnup level will not exceed the burnup levels for which the computer codes and analysis methods were approved.

\subsection{FISSION-PRODUCT RELEASE FROM FUEL AT EXTENDED BURNUP}

Two components are involved in determining the amount of radioactive fission gas released from the fuel. The first is the fission-product (see Glossary) inventory in the fuel that is available for release, and the second is the fraction of these products that is actually released to the fuel cladding gap during normal operation and various accident situations. It should be noted that several barriers exist in a commercial plant before these fission products can be released to the outside atmosphere. The fuel cladding, primary containment, and reactor containment are three of the major barriers. In addition to these barriers, there are many other physical and chemical avenues of holdup in the pathway from the fuel rod to the outside atmosphere. The various accident scenarios that can release fission products and their consequences are discussed in detail in Section 3.2 . 
The change in fission-product inventory in the fuel as a result of extended burnup operation is given in Table 2.2 as a change factor from the inventory calculated at a current burnup level of $33 \mathrm{GWd} / \mathrm{t}$. The inventories and resulting change factors have been calculated from the ORIGEN2 computer program (Croff 1980) for several fission products and actinides (see Glossary) for the two burnup levels immediately following shutdown (i.e., no time for radioactive decay). The radionuclides given are those contributing most to risk from both normal operation and accidents. As can be seen from the table, only the long half-life (see Glossary) fission products, such as strontium90, ruthenium-106, and cesium-134 and -137 , increase much with burnup. There is, however, generally a larger increase for actinides.

Because the fractional releases of the fission-product gases into the fuelcladding gap have an important bearing on the effects of ruptures of the fuel cladding during normal operation and severe accidents, extensive studies of this phenomenon, both theoretical and experimental, have been conducted. The DOE extended burnup programs have obtained fission-gas release data for the noble gases during normal operation at rod average burnups (see Glossary) of up to $62 \mathrm{GWd} / \mathrm{t}$. These data have shown that fission-gas release into the fuel-cladding gap increases with increasing burnup. A few fission-product release models have been developed to explain the increase in release with burnup. The ANS 5.4 fission-product release model (Turner et al. 1982) is one of the more widely known of these models and was developed by an American Nuclear Society group of experts as an "American National Standard for Calculating the Fractional Release of Volatile Fission Products from Oxide Fuel."

The release of volatile radioactive fission products from the fuel to the fuel-cladding gap is of great importance in this study. The fuel-cladding gaprelease fraction (see Glossary) from normal reactor operation is important for those accidents and off-normal events that do not involve fuel thermal transients, but which can still lead to fuel-cladding leaks with subsequent releases of radionuclides to the environment (e.g., the fuel handling accident).

Calculations have been performed with the ANS 5.4 release model to determine the maximum possible gap-release fraction of each of the volatile fission products. These results are presented in Section 3.2.2, where the environmental effects of the fuel-handling accident are discussed; however, a brief description of these bounding calculations and how they compare to the majority of the gap-release fractions observed in commercial plants will be discussed in this section. To bound the maximum possible releases for normal operation at extended burnup, the calculations performed in Section 3.2.2 are based on the maximum possible end-of-life rod pressure criteria approved by the NRC, which in turn applies to the peak rod in a reactor core.

It should be noted that the fission-product release from the peak operating rod in any given reactor core will be substantially greater than those from 95 to $99 \%$ of the fuel rods in a fuel batch at extended burnup. For example, 95 to $99 \%$ of the rods in any given fuel batch at a batch average burnup of $50 \mathrm{GWd} / \mathrm{t}$ have fission-gas (noble) release fractions between 0.015 and 0.025 (Pati and Garde 1985), whereas the calculated peak rod in the batch may have release fractions two to five times this amount. At the current batch average 
TABLE 2.2. Radionuclides Contributing to Environmental Impacts from Normal Operational and Accidental Releases to Biosphere Showing the Change Factor at Shutdown Resulting from an Increase in Burnup Level from 33 to $60 \mathrm{GWd} / \mathrm{t}$

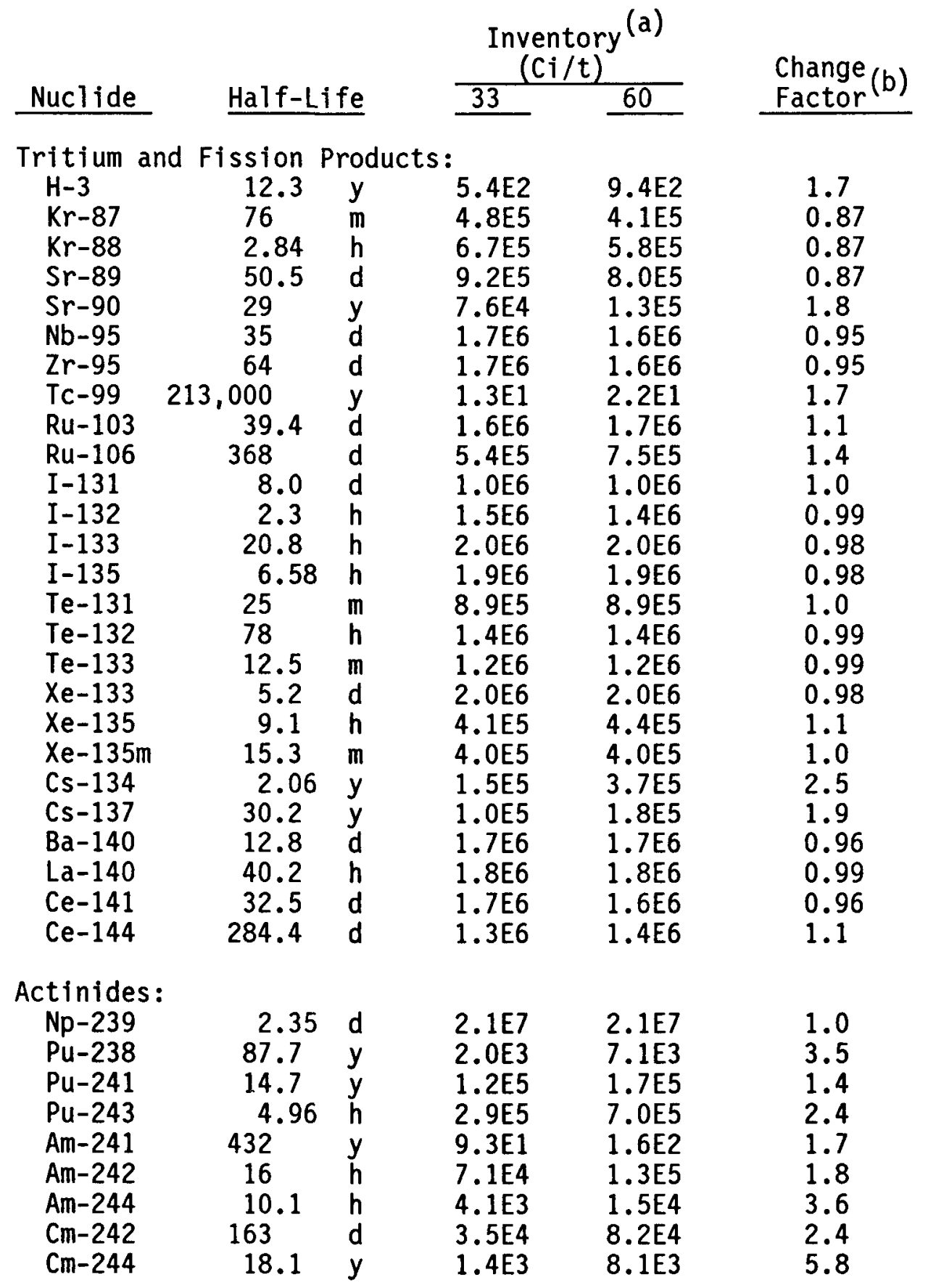

(a) ORIGEN2 (Croff 1980). See Appendix A.

(b) Inventory for $60 \mathrm{GWd} / \mathrm{t}$ divided by inventory for $33 \mathrm{GWd} / \mathrm{t}$. 
burnup of $33 \mathrm{GWd} / \mathrm{t}$ the majority of the rods (95\% or more) in a fuel batch with an extended burnup fuel design will have release fractions less than or equal to 0.01 , with the calculated peak rod having release fractions three to five times this amount.

A calculation of the release of several radionuclides from the average rod in the core at extended burnup is provided in Section 3.1.5, as well as estimates of average activity increase in the coolant from normal operation with the introduction of extended burnup fuel. 


\subsection{ENVIRONMENTAL EFFECTS}

This chapter describes the effects on the environment of an increase in burnup of nuclear fuel used in commercial power reactors. The environmental effects are addressed in terms of the net change in radiological impacts, considering both normal and accident conditions, of various activities and processing operations of the uranium fuel cycle.

The uranium fuel cycle, depicted in Figure 3.1, consists of mining of the natural uranium, processing the ore in mills to uranium oxide ( $\mathrm{UO}_{2}$, yellowcake), converting the yellowcake (see Glossary) to uranium hexafluoride $\left(U_{6}\right)$ gas, enriching this gas to higher concentrations of uranium-235, and converting to $\mathrm{UO}_{2}$. The $\mathrm{UO}_{2}$ is pelletized, sintered, and inserted into rods in fuel fabrication plants (see Glossary). These rods are combined into fuel assemblies and shipped to reactors as fuel to produce power. After the fuel reaches a specified burnup level, the spent-fuel assemblies are removed from the reactor and stored at the site in water pools to cool both thermally and radioactively. Finally, the spent-fuel assemblies are shipped to either a reprocessing plant (see Glossary) or a high-level waste repository for final burial. At present the spent fuel has not been moved from the at-reactor storage (see Glossary) pools because no reprocessing plants are in operation and a high-level waste repository has not been constructed.

This discussion covers the incremental changes of radionuclide releases and their impacts that would be produced from both normal operation and accidents as a result of the increase in fuel burnup. The following points, which were discussed in Chapter 2.0, should be noted:

- Short-lived fission-product activity in the fuel itself is not appreciably affected by the amount of burnup. However, the fission products released into the fuel-cladding gap may increase with burnup, depending on the nuclide and accident scenario in question. These fission products are responsible for almost all of the exposure from the normal operation of the reactor or from accidental releases from the reactor.

- In general, most long-lived nuclides, such as long-lived fission products and actinides, will increase roughly in proportion to the amount of burnup. However, compared to short-lived fission products, such as iodine-131, these long-lived nuclides contribute insignificantly to exposures until the inventory of fission products has been aged a few years.

\subsection{EFFECTS FROM NORMAL OPERATION}

In the following discussion, the radiological impacts of increased burnup for the normal operation of an LWR as well as the front and back ends of the nuclear fuel cycle are described. Subsections dealing with effects from parts of the fuel cycle that are not part of reactor operation, such as mining and milling (see Glossary), conversion (see Glossary) and enrichment, fuel fabrication, transportation, waste management, and reprocessing, are based on the recent Atomic Industrial Forum's National Environmental Studies Project report on The Environmental Consequences of Higher Fuel Burnup (Mauro et al. 1985). 


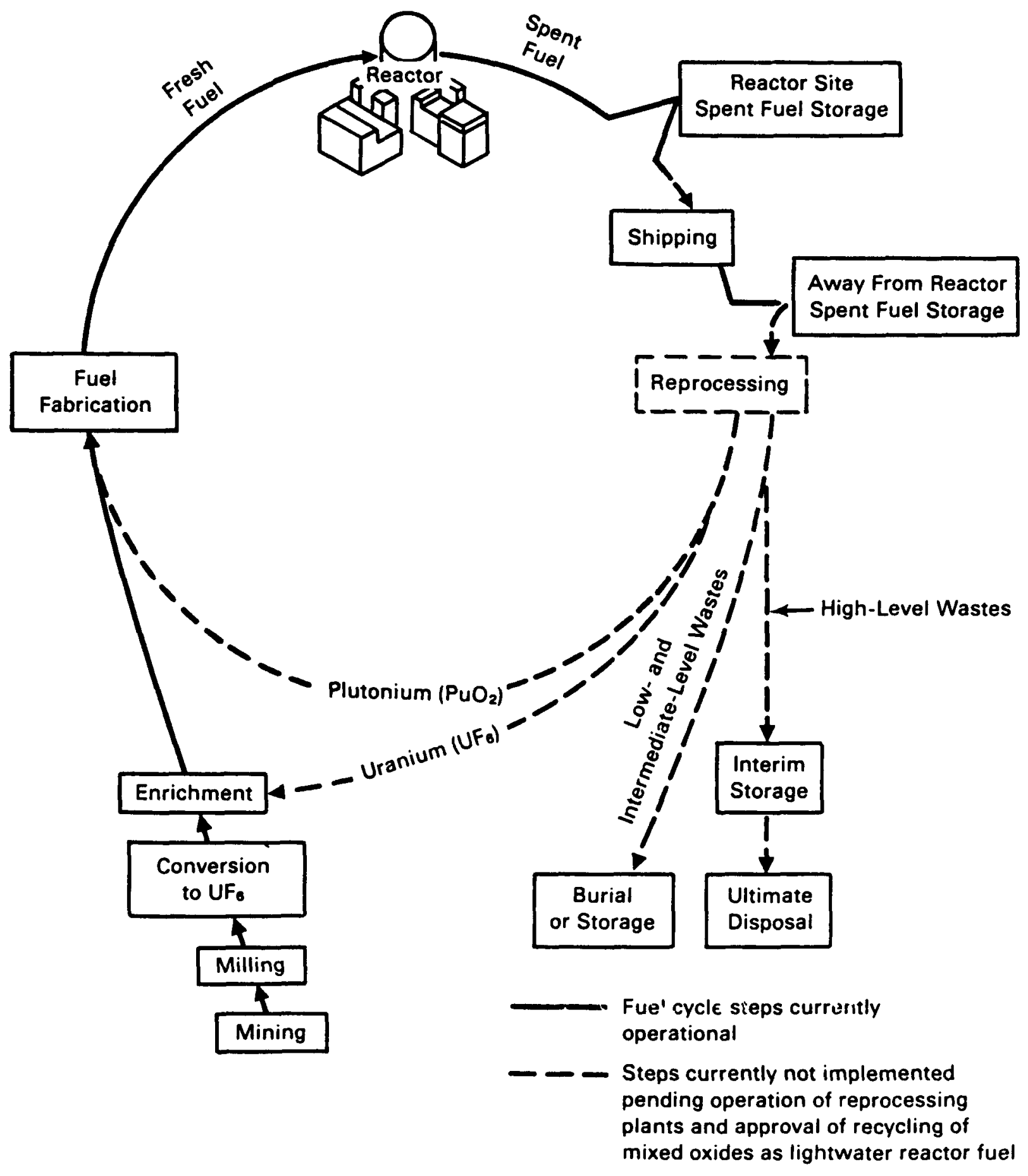

FIGURE 3.1. The Uranium Fuel Cycle 


\subsubsection{Mining and Milling}

The amount of uranium mined and milled would be reduced with extended burnup. Although the amount of fuel that would be produced would drop $45 \%$ in inverse proportion to the change in burnup $(33 / 60=0.55$, or a decrease of 0.45 ), the quantity of ore mined would drop only $5 \%$ when the burnup level is increased from 33 to $60 \mathrm{GWd} / \mathrm{t}$ (Mauro et al. 1985, Table 3-11). This behavior was determined by performing detailed reactor-physics and fuel-cycle analyses to estimate ore requirements as a function of fuel burnup (Mauro et al. 1985).

During milling, only a 5\% decrease in the releases of radium-226, thorium230, and uranium and daughters is expected when burnup level is increased to $60 \mathrm{GWd} / \mathrm{t}$ (Mauro et al. 1985, Table 3-13). Thus, the radiological impacts from these processes would be proportionally reduced.

\subsubsection{Conversion and Enrichment}

The radiological impacts from converting yellowcake to $\mathrm{UF}_{6}$ would be reduced $5 \%$ when increasing the burnup level from the present 33 to $60 \mathrm{GWd} / \mathrm{t}$ (Mauro et al. 1985, Table 3-14) in the same proportion as the quantity of ore mined. These reductions arise because of the reduced releases of uranium and daughters, radium-226, and thorium-230 into the environment. The radiological impacts of the uranium-235 enrichment process decrease slightly and then rise with increasing burnup having a minimum impact at about 45 to $50 \mathrm{GWd} / \mathrm{t}$. The overall change from 33 to $60 \mathrm{GWd} / \mathrm{t}$ is an increase of about 1\% (Mauro et al. 1985, Table $3-15)$. The radiological impact of this slight increase is not considered significant.

\subsubsection{Fuel Fabrication}

Although the enrichment of high-burnup fuel will increase, any exposure to the fuel by fuel-plant workers or the surrounding general population (see Glossary) will be maintained at the same level by operational procedures if necessary. Thus, no change in radiological impacts to workers is expected. However, since the throughput decreases inversely with increasing burnup level, the radiological impacts from uranium and daughters and from thorium-234 releases would decrease proportionally (-45\%) (Mauro et al. 1985, Table 3-16).

\subsubsection{Refueling}

Impacts associated with refueling of the reactors would decrease in proportion to the amount of fuel throughput, which is reduced inversely to fuel burnup. Thus, the exposure to workers from refueling operations is expected to decrease $45 \%$ when increasing from 33 to $60 \mathrm{GWd} / \mathrm{t}$ burnup.

\subsubsection{Reactor Operation}

During normal reactor operation, the fuel cladding surrounding the fuel pellets prevent radionuclides from entering the reactor cooling water. However, from time to time a fuel rod may become defective and release small amounts of radionuclides into the cooling water. This radioactivity (see Glossary) is then quickly removed by the plant cooling-water cleanup system. 
The normal reactor coolant contamination may be increased by the following three processes:

1. increase in the number of leaking fuel rods

2. increase in the activity (inventory) of radionuclides inside the fuel pellets

3. increase in the activity in the gap between the fuel pellets and the cladding (gap activity).

Results from the studies discussed in Chapter 2.0 show that the integrity of the fuel rods undergoing extended burnup has not decreased as a result of increasing irradiation (Lang 1986). Thus, fuel-rod leakage is not expected to increase over that from normal burnup for rod average burnups up to $60 \mathrm{GWd} / \mathrm{t}$.

However, a slight increase in inventory and fuel-cladding gap-release fractions will occur for some fission products in those rods at extended burnup. If leakage occurs, the increased contamination would normally be removed from the reactor coolant by the plant cleanup system, and the reactor would be shut down if excessive radioactivity were detected (i.e., exceed technical specification limits for the plant). Data for the radionuclides that constitute the greatest contribution to doses (see Glossary) to individuals and populations residing around LWRs are given in Table 3.1. This table shows the relative inventory change factor for each radionuclide due to an increase in burnup from 33 to $60 \mathrm{GWd} / \mathrm{t}$, as presented earlier in Table 2.2. Also presented are the release fraction and relative change factor for each radionuclide as calculated using the ANS 5.4 (Turner et al. 1982) model for the average rod from a typical normal and extended burnup fuel design. As noted in Section 2.2, 95 to $99 \%$ of all fuel rods in a reactor core at this burnup level will have release fractions near these values. Also given in this table is the overall change factor for high burnup--the product of the inventory and release fraction factors due to the batch average rod increasing in burnup from 33 to $60 \mathrm{GWd} / \mathrm{t}$.

As can be seen from Table 3.1, only cesium increases by a factor of four or more; however, the normal plant cleanup systems can easily handle this increase during normal operation. Thus it is anticipated that the environmental impact for normal operation will not change when extending fuel burnup.

\subsubsection{Iransportation}

Transportation environmental effects result from transporting fresh fuel assemblies to the reactor site, shipping spent fuel from the site to a reprocessing or waste-isolation facility, and shipping solid waste to a low-level burial ground (Mauro et al. 1985). 
TABLE 3.1. Major Contributory Radionuclides for Burnups of 33 and $60 \mathrm{GWd} / \mathrm{t}$ Released into the Cooling System During Normal Operation, and Their Associated Change Factors

\begin{tabular}{|c|c|c|c|c|c|}
\hline \multirow{2}{*}{ Nuclide } & \multirow{2}{*}{$\begin{array}{l}\text { Inventory } \\
\text { Change (a) } \\
\text { Factor } \\
\end{array}$} & \multicolumn{2}{|c|}{$\begin{array}{l}\text { Release } \\
\text { Fraction } \\
33\end{array}$} & \multirow[t]{2}{*}{$\begin{array}{l}\text { Release } \\
\text { Fraction } \\
\text { Change (c) } \\
\text { Factor } \\
\end{array}$} & $\begin{array}{l}\text { Overall } \\
\text { Change }(d) \\
\text { Factor }\end{array}$ \\
\hline & & & & & \\
\hline $\begin{array}{l}\mathrm{Cs}-134 \\
\mathrm{Cs}-137 \\
\mathrm{H}-3 \\
\mathrm{I}-131 \\
\mathrm{Kr}-87 \\
\mathrm{Kr}-88 \\
\mathrm{Sr}-90 \\
\mathrm{Xe}-133 \\
\mathrm{Xe}-135\end{array}$ & $\begin{array}{l}2.5 \\
1.9 \\
1.7 \\
1.0 \\
0.87 \\
0.87 \\
1.8 \\
0.98 \\
1.1\end{array}$ & $\begin{array}{c}9.0 \mathrm{E}-3 \\
1.4 \mathrm{E}-2 \\
(\mathrm{e}) \\
5.0 \mathrm{E}-3 \\
1.6 \mathrm{E}-4 \\
2.0 \mathrm{E}-4 \\
(\mathrm{e}) \\
1.6 \mathrm{E}-3 \\
4.0 \mathrm{E}-4\end{array}$ & $\begin{array}{c}1.7 \mathrm{E}-2 \\
2.7 \mathrm{E}-2 \\
(\mathrm{e}) \\
9.0 \mathrm{E}-3 \\
3.0 \mathrm{E}-4 \\
4.0 \mathrm{E}-4 \\
(\mathrm{e}) \\
3.0 \mathrm{E}-3 \\
8.0 \mathrm{E}-4\end{array}$ & $\begin{array}{l}2 \\
2 \\
1 \\
2 \\
2 \\
2 \\
1 \\
2 \\
2\end{array}$ & $\begin{array}{l}5 \\
4 \\
2 \\
2 \\
2 \\
2 \\
2 \\
2 \\
2\end{array}$ \\
\hline
\end{tabular}

(a) From Table 2.2 of this report.

(b) The average rod for a typical high-burnup fuel design as of 1986 .

(c) Release fraction at $60 \mathrm{GWd} / \mathrm{t}$ divided by release fraction at $33 \mathrm{GWd} / \mathrm{t}$.

(d) Product of inventory change factor and release fraction change factor to one significant digit.

(e) The ANS 5.4 model is not capable of calculating release fractions for this radionuclide.

\subsubsection{Transport of Fresh Fuel Assemblies}

The only difference in the activity inventory of fresh fuel designed for high burnup compared to normal fuel would be due to the increase in uranium235 enrichment from about $3.5 \%$ to around $5 \%$. This increase would have an insignificant effect on exposures resulting from transport of the fuel from the fabrication plants to the reactor sites. The reduction in throughput brought about by the increase in burnup level would reduce truck shipments from six to four per year, which would reduce doses received by transportation workers and the general public by about $40 \%$, from 0.014 to 0.009 man-rem (see Glossary) (Mauro et al. 1985, Table 4-3).

\subsubsection{Shipment of Spent Fuel}

Spent fuel is shipped from the reactor site to a reprocessing plant or repository by truck, railroad car, or barge. The doses to the transport workers and population would be reduced as a result of changing to a higher burnup fuel. By increasing the storage time at the reactor site for high burnup fuel, the radioactivity in the fuel elements can be allowed to decay so that the heat generated in a shipping cask and, hence, the number of fuel assemblies carried per trip could remain unchanged.

An increase in the emission of neutrons by a factor of 5.6 is expected with the use of $60 \mathrm{GWd} / \mathrm{t}$ fuel. This value was derived from the ORIGEN2 computer 
code using parameters listed in Appendix A. These neutrons are primarily generated by the spontaneous emissions from americium-241, plutonium-238, and curium-244. With minor modifications to the shipping casks (such as extra shielding if necessary and borated cooling water), higher burnup fuel may be carried, while still adhering to the Department of Transportation (DOT) regulatory limits for radiation (see Glossary) fields outside the cask. One shipping-cask firm that uses "dry" neutron shielding considers their casks to be able to handle fuel at an average burnup level of $55 \mathrm{GWd} / \mathrm{t}$ (Planell et al. 1983). Another company using water for a neutron shield claims most of its casks will be acceptable up to this burnup level after minor physical modifications or $1 \%$ boron is added to the water shield tank (Viebrock and Schreiber 1983).

Because the number of fuel shipments would be inversely proportional to the increase in burnup $(33 / 60=0.55)$, the radiation impact would be reduced by $45 \%$, assuming the radiation field stayed the same (Mauro et al. 1985, p. 412). Table 3.2 shows that the impacts of transporting spent fuel when increasing burnup would be equally reduced by $45 \%$ for three modes of transport, since fewer trips would be needed per reactor year of operation.

\subsubsection{Shipment of Solid Waste}

Solid waste consists of radioactive sludges and resins collected from contaminated spent-fuel storage water and reactor coolant. An increase in solid waste would be caused by an increase in the contamination levels of the cooling water used for spent-fuel storage and reactor operation. Any increase in leaking fuel rods would thus contribute to the solid waste. Although the leakage rate of the fuel rods is expected to remain the same for the higher burnup fuel (Lang 1986; Rubenstein and Tokar 1982), slight increases in coolingwater activity could occur through increased inventory and gap-release fraction

TABLE 3.2. Estimated Population Doses to Workers and the General Public for Three Types of Spent-Fuel Carriers for 33 and $60 \mathrm{GWd} / \mathrm{t}$ Burnup Fuel

Spent-Fuel Carrier

\begin{tabular}{|c|c|c|c|c|c|}
\hline \multicolumn{2}{|c|}{ Truck } & \multicolumn{2}{|c|}{ Rail } & \multicolumn{2}{|c|}{ Barge } \\
\hline 33 & 60 & 33 & 60 & 33 & 60 \\
\hline 60 & 33 & 10 & 6 & 5 & 3 \\
\hline
\end{tabular}

$\begin{array}{lllllll}\begin{array}{c}\text { Annual Dose (man-rem) } \\ \text { Workers }\end{array} & 1.2 & 0.7 & 2 . & 1.2 & 0.04 & 0.02 \\ \begin{array}{l}\text { General Public: } \\ \text { Onlookers }\end{array} & 0.8 & 0.5 & 0.1 & 0.1 & -- & -- \\ \quad \text { Along Route } & \underline{1.1} & \underline{0.6} & \underline{0.2} & \underline{0.11} & \underline{0.03} & \underline{0.02} \\ \text { TOTAL DOSE } & 3.1 & 1.8 & 2.3 & 1.4 & 0.07 & 0.04\end{array}$

Source: Mauro et al. 1985, Tables 4-6 through 4-8. 
(see Table 3.1). Because this activity would need to be removed to keep the cooling water at the licensed technical specifications, an increase in solid waste would possibly result.

In consideration of this, Mauro et al. (1985, p.4-19) evaluated the effect of a $20 \%$ increase in solid waste for the case of extended burnup. Taking the trucking case as an example, Table 3.3 shows that the radiological impacts to workers and the general public from the shipment of solid waste would also increase by the same factor (20\%) when changing to high burnup fuel. Similarly, doses would change by the same factor for rail and barge shipments.

\subsubsection{Waste Management}

Using high burnup fuel would reduce the annual throughput of spent fuel in proportion to the increase in burnup. Because of this reduction in throughput, impacts from spent-fuel storage and final disposal in a waste repository would generally be reduced. Table 3.4 summarizes the changes in radiological impacts from changing to high burnup fuel for various waste-management activities. In general, the impacts decrease, except possibly for low-level waste disposal, which could rise through the increase in reactor cooling-water decontamination. However, the longer cooling times that would be required before shipment may result in the need for more reactor storage space. The general effect in waste management of increasing fuel burnup is a decrease in the impacts.

TABLE 3.3. Estimated Population Doses to Workers and the General Public for Solid Waste Shipments by Truck for 33 and $60 \mathrm{GWd} / \mathrm{t}$ Burnup Fuel

\begin{tabular}{lll} 
& \multicolumn{2}{c}{ Truck } \\
\cline { 2 - 3 } & 33 & $\frac{60}{20}(\mathrm{a})$ \\
Increase in Waste (\%) & -- & 55 \\
Shipments per Year & 46 & 5 \\
$\begin{array}{l}\text { Annual Dose (man-rem) } \\
\text { Workers } \\
\text { General Public: } \\
\begin{array}{l}\text { Onlookers } \\
\text { Along Route }\end{array}\end{array}$ & 1.0 & 1.1 \\
TOTAL DOSE & $\underline{0.4}$ & $\underline{0.5}$ \\
& 2.0 & 2.3
\end{tabular}

Source: Mauro et al. 1985, Table 4-10.

(a) Arbitrarily selected. 
TABLE 3.4. Summary of Changes in Radiological Impacts for Various WasteManagement Activities for Increasing Fuel Burnup from 33 to $60 \mathrm{GWd} / \mathrm{t}$

\begin{tabular}{|c|c|c|c|}
\hline Activity & $\%$ Change & Primary Contributors & Reference ${ }^{(a)}$ \\
\hline $\begin{array}{l}\text { Decommissioning } \\
\text { \& decontamination }\end{array}$ & $\begin{array}{l}-16 \\
-28 \\
-45 \\
-12\end{array}$ & $\begin{array}{l}\text { Ra-226, Th-230 } \\
U \\
U \text { \& daughters } \\
\text { Fission and activation } \\
\text { products }\end{array}$ & Table 3-17 \\
\hline
\end{tabular}

Low-level waste disposal

0 to 20
Cs, corrosion, activa- tion, and fission products

p. $3-26$ and

p. $4-19$

High-level waste disposal

Tritium, $\mathrm{Kr}-85$, fission products and transuranics

Table $3-20$

$r-85$

Table 3-21

At-reactor storage

$-8$

$\mathrm{Kr}-85$

Table 3-22

Packaging spent fuel

$-8$

(a) Source: Mauro et al. 1985

\subsubsection{Reprocessing}

During the reprocessing of spent fuel, the environmental impacts would be from the exposures of certain long-lived radionuclides in the fuel. These nuclides would, in general, increase proportionally with burnup. However, the amount of fuel undergoing reprocessing would be reduced in proportion to the burnup. The combination of these two effects results in a net reduction in the exposure and, hence, a reduction in the radiological impacts (see Table 3.5). Nonradiological impacts would be reduced with increasing burnup (Mauro et al. 1985, p. 3-34) in direct proportion to the fuel throughput.

\subsection{EFFECTS FROM ACCIDENTS}

The following discussion considers both fairly large accidents in which the fuel in the core has been damaged or melted and a smaller accident in which only one fuel rod ruptures. A transportation accident is also discussed.

\subsubsection{Fuel-Damage Accident}

A fuel-damage accident is one in which fuel damage occurs as, for example, in a loss-of-coolant-accident (LOCA) in which the emergency core cooling is 
TABLE 3.5. Summary of Changes in Radiological Impacts

from Reprocessing for Increasing Fuel

Burnup from 33 to $60 \mathrm{GWd} / \mathrm{t}$

\begin{tabular}{c} 
\% Change \\
\hline-22 \\
-4 \\
-8 \\
-3 \\
-44 \\
-34
\end{tabular}

Contributor

C-14, Ru-106, U

Tritium

$\mathrm{Kr}-85$

I-129

I-131

Fission Products and

Transuranics

Source: Mauro et a1. 1985, Table 3-24.

degraded. A LOCA is postulated to be the result of a major break in the primary coolant pipe so that the supply of cooling water to the reactor core is abruptly cut off. If emergency cooling water is not quickly applied, the fuel may be damaged or an appreciable fraction of the fuel in the core would melt, and, thus, radionuclides would be released from inside the failed fuel rods to the containment and, if not held up or filtered, to the biosphere.

During an accident in which the core is damaged but no appreciable melting of fuel occurs and the containment system works fairly well, as was experienced at the Three Mile Island reactor (TMI-2), only the most volatile radionuclides will be released from the fuel and possibly pass through filters to enter the biosphere. These nuclides include the short-lived fission products such as the iodines and noble gases: lodine-131, lodine-133, xenon-133, xenon-133m, xenon135, xenon-135m, and krypton-88 (Rogovin 1980, Table II-1). Because of the short half-lives of these nuclides, they do not increase with burnup. Thus, for this type of accident, no increase in accident consequences would occur by using higher burnup fuel.

For the release of the fission-product gases from severe accidents that involve significant fuel melting [e.g., Class 9 accidents (see Glossary)], not only are the most volatile radionuclides released, like the iodines and noble gases, but a substantial percentage of other semivolatile and nonvolatile fission products are also released, such as cestum and actinides. The NRC source term work (Silberberg et al. 1986) has addressed the release of fission products during Class 9 accidents. The percentage of fission-product inventory released from the fuel would not likely change as a result of extended burnup; however, the fission-product inventory in the fuel would change for the long half-life fission products and actinides, as shown in Table 2.2 The increase factors from this table show the change in relative inventory of each of the radionuclides from the current burnup level of $33 \mathrm{GWd} / \mathrm{t}$ to that present at $60 \mathrm{GWd} / \mathrm{t}$.

As can be seen from Table 2.2, of the fission products, only strontium-90, ruthenium-106, and the cesiums increase much with burnup--less than a factor of three. The actinides increase more with the increase in burnup. However, 
during an accident, these actinides contribute only minimally to doses, compared to the fission products. The main concern for these actinides would be from the standpoint of long-term effects of inhalation (lung dose) and ingestion of food products (vegetables, milk, and meat) raised in or fed from fodder grown in contaminated soil.

Although the actinides, plutonium-238 and curium-244, increase more than twice with increase in burnup ( 3.5 and 5.8 times, respectively), they do not correspondingly contribute more to the accident risk. This is because the accident risk from these actinides results primarily from the ingestion of food products produced on contaminated soil years after the accident. The fission products, cesium-137 and strontium-90, however, contribute much more to this risk because the release fractions and plant biotransfer factors (see Glossary) are much smaller for plutonium and curium than for cesium and strontium. Thus the accident risk of Class 9 accidents is increased only by a factor of two with the increase in fuel burnup level from 33 to $60 \mathrm{GWd} / \mathrm{t}$.

In addition, since there is an order of magnitude uncertainty in the risk estimates for accidents, the increased risk from the increases in actinides brought on by the higher burnup level are small compared to these uncertainties.

\subsubsection{Fuel-Handling Accident}

A fuel-handling accident could be caused by dropping a fuel assembly while removing the spent fuel from the core, placing the assembly in a spent fuel pool, or loading it for transport. This type of accident could result in the rupture of the fuel-rod cladding and subsequent release of volatile nuclides contained in the gap between the fuel and cladding. For current-burnup fuel, the fraction of volatile nuclides contained in this gap (gap fraction) has been conservatively assumed to be $10 \%$ (except krypton-85, which is $30 \%$ ) in Regulatory Guide 1.25 (NRC 1972).

Recent studies by the DOE and the reactor fuel vendors (Lang 1986) have shown that fuel rods with peak burnups of $60 \mathrm{GWd} / \mathrm{t}$ suffer no more decrease in cladding integrity than rods of $33 \mathrm{GWd} / \mathrm{t}$. Thus, when changing to higher burnup, the probability of fuel-handling accidents during fuel removal would not increase.

Because the fuel-handling accident is a single-assembly or individual-rod accident, and, in order to bound the possible releases from this type of accident, we evaluated the release from the peak operating rod in a fuel batch of a fuel design with high operating powers.

The NRC imposes a pressure limit on end-of-life internal fuel rod pressures for normal reactor operation. This limits the amount of gas that can be released for any given fuel design. Traditionally, the internal rod pressure limit has been set equal to the reactor system pressure; i.e., 2,250 psi for PWRs, and 1,050 psi for BWRs (NRC 1981). However, with the introduction of extended burnup operation, some fuel vendors have requested (Charnley 1983; Risher et al. 1977) and NRC has approved (Thomas 1985a,b; Stoltz 1978) internal rod pressure limits that are vendor-specific. These pressure limits are proprietary to the vendor. 
The burnup level at which the pressure limit is achieved is dependent on both the design of the reactor and the fuel rod. The expected release fraction of the stable (nonradioactive) noble gases for the peak calculated rod in a fuel batch is about 0.14 (14\%) for a high-power fuel design in both PWRs and BWRs. This estimated release fraction is based on the NRC-imposed pressure limits for normal operation at rod average burnups of $55 \mathrm{GWd} / \mathrm{t}$ and $60 \mathrm{GWd} / \mathrm{t}$ for BWRs and PWRs, respectively. This is less than the $30 \%$ release for krypton85 that is assumed in Regulatory Guide 1.25 (NRC 1972) for fuel-handling accidents and significantly less than the $100 \%$ release assumed in Regulatory Guides 1.3 and 1.4 (NRC 1974a,b) for a LOCA. The amount of the krypton-85 isotope can conservatively be assumed to stay constant for the accidents considered because of its long half-life (10.7 years). All other shorter halflife isotopes of the noble gases would have lower release amounts because of radioactive decay before their release from the fuel. For example, for an accident involving the handling of spent fuel, the NRC in Regulatory Guide 1.25 (NRC 1972) stipulates a $10 \%$ release for all radioactive noble gases and iodine with the exception of krypton-85, for which a $30 \%$ release is stipulated. Regulatory Guide 1.25 has been generically approved (Hulman 1982) for evaluating fuel that is to attain batch average burnups as high as $38 \mathrm{GWd} / \mathrm{t}$ discharge.

The release fractions calculated for the radioactive iodine and cesium are given in Table 3.6 and compared to those assumed in Regulatory Guides 1.25 , and 1.3/1.4 for fuel-handling accidents and LOCA, respectively. As shown in Table 3.6 , the release fractions calculated from this study for the shorter half-life isotopes are smaller than those for the longer half-life isotopes. As noted earlier, this is because of the significant amount of decay experienced by the short-lived isotopes before their release from the fuel. A comparison of the release fractions in Table 3.6 shows that the values calculated in this report for extended burnup fuel are all higher than those for the low burnup fuel. However, the extended burnup release fractions are all lower than those assumed in the Regulatory Guides, with the exception of iodine-131. For this report, we have calculated a release fraction of 0.12 for iodine for a peak rod at a burnup level of $60 \mathrm{GWd} / \mathrm{t}$, whereas Regulatory Guide 1.25 assumes a release fraction of 0.10 (normal burnup).

The release fractions for the shorter half-life isotopes in this report have been calculated from the 0.14 fractional release for stable noble gases using the ANS 5.4 fission-product release model (Turner et al. 1982). It should be noted that the ANS 5.4 fission-product model considers only krypton, xenon, iodine, cesium, and tellurium fission products. As per ANS 5.4, the diffusion coefficients for iodine and cesium are factors of seven and two higher, respectively, than those for noble gases.

Thus, we conclude that Regulatory Guide 1.25 procedures may be used for extended burnup fuel. These procedures give conservative values for noble gas release fractions that are above calculated values for peak rod burnups of $60 \mathrm{GWd} / \mathrm{t}$, except for iodine-131, which may be up to $20 \%$ higher. 
TABLE 3.6. Calculated Release Fractions in the Fyej-Cladding Gap of the Peak Fuel Rod During Normal Operation $(a)$ at Current and Extended Burnup Levels of 33 and $60 \mathrm{GWd} / \mathrm{t}$ (rod average) Compared with Gap-Release Fractions Assumed in Regulatory Guides

\begin{tabular}{|c|c|c|c|c|}
\hline \multirow[b]{2}{*}{ Nuclide } & \multicolumn{2}{|c|}{$\begin{array}{c}\text { Calculated } \\
\text { Peak Rod }\end{array}$} & \multirow{2}{*}{$\begin{array}{c}\text { Assumed in } \\
\text { Reg. Guide } 1.25 \\
\text { (Fuel-Handling Acc.) }\end{array}$} & \multirow{2}{*}{$\begin{array}{l}\text { Assumed in } \\
\text { Reg. Guide } 1.3 / 1.4 \\
\text { (LOCA) }\end{array}$} \\
\hline & 33 & 60 & & \\
\hline $\mathrm{Kr}-85$ and Stable & & & & \\
\hline $\begin{array}{c}\text { Noble } \mathrm{Ga} \\
\mathrm{Kr}-87\end{array}$ & 0.04 & 0.14 & 0.30 & 1 \\
\hline $\mathrm{Kr}-87$ & 0.002 & 0.007 & 0.1 & 1 \\
\hline $\mathrm{Kr}-88$ & 0.003 & 0.01 & 0.1 & 1 \\
\hline$X e-133$ & 0.015 & 0.05 & 0.1 & 1 \\
\hline $\mathrm{Xe}-135$ & 0.008 & 0.02 & 0.1 & 1 \\
\hline Cs-134 & 0.03 & 0.11 & (b) & (b) \\
\hline Cs -137 & 0.05 & 0.17 & (b) & (b) \\
\hline $\mathrm{I}-$ & 0.04 & 0.12 & 0.1 & 0.25 \\
\hline
\end{tabular}

(a) Excludes accidents but includes normal operational transients as allowed by the technical specifications.

(b) Not given in Regulatory Guides.

\subsubsection{Transportation Accident}

Environmental impacts from an accident during the transport of the higher burnup fuel from the reactor to a disposal site or reprocessing plant would increase with extended burnup. The activity of the fission products that contribute most to a nuclear accident source term, such as iodine-131, are not significant in transportation accidents because they would have decayed before transport begins. However, some of the long lived actinides would contribute to the risk. Table 3.7 shows the major radionuclides contributing to the inhalation impact (effective dose) of an accident of such magnitude that all of the activity inventory of the fuel is vaporized and inhaled. The activity inventory is that contained in spent fuel after 5 years cooling. All other radionuclides in the fuel would contribute less than $1 \%$ of the dose. The overall increase factor for the accident impact is 2.7 (sum of effective doses at $60 \mathrm{GWd} / \mathrm{t}$ divided by that at $33 \mathrm{GWd} / \mathrm{t}$ ). The contributing nuclides listed in the table are similar to those previously found to be significant by Mattsen (1979). However, because the use of extended burnup fuel would reduce the need for fuel, the number of shipments would also be reduced. With fewer shipments, chances of an accident would be less. The above increase factor of 2.7 would then be reduced by the factor of $33 / 60$ to account for the reduced shipments:

$$
2.7 \times 33 / 60=1.5
$$


TABLE 3.7. Major Contributing Radionuclides Resulting from a Transportation Accident Involving the Release of Spent Fuel

\begin{tabular}{|c|c|c|c|c|c|c|c|c|c|}
\hline Nuclide & $\begin{array}{l}\text { Half-Lifo } \\
\frac{(y)}{}\end{array}$ & $\begin{array}{l}\text { Inhalation } \\
\text { Dose Factor (a) } \\
\text { (nrem/Ci) }\end{array}$ & $\begin{array}{l}\text { Inventory } \\
33\end{array}$ & $\frac{(\mathrm{ci} / \mathrm{t})^{(b)}}{\underline{60}}$ & $\begin{array}{c}\text { Increase } \\
\text { Factor }\end{array}$ & $\begin{array}{r}\text { Eff. Do } \\
33 \text { Gild } \\
\text { (mron) }\end{array}$ & $\begin{array}{l}t \\
\text { c) }\end{array}$ & $\begin{array}{l}\text { Eff. Do } \\
60 \text { Gild } \\
\text { (inren) }\end{array}$ & \\
\hline 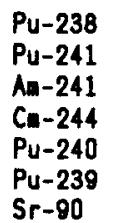 & $\begin{array}{c}87.7 \\
14.7 \\
432 \\
18.1 \\
6537 \\
24110 \\
29\end{array}$ & $\begin{array}{l}4.9 E 11 \\
1.1 \mathrm{E} 10 \\
5.6 \mathrm{E} 11 \\
2.8 \mathrm{E} 11 \\
\text { 8.0E11 } \\
6.8 \mathrm{E} 11 \\
1.4 \mathrm{Eg}\end{array}$ & $\begin{array}{l}2.2 E 3 \\
9.2 E 4 \\
9.3 E 2 \\
1.2 E 3 \\
6.1 E 2 \\
3.1 E 2 \\
6.7 E 4\end{array}$ & $\begin{array}{l}7.3 E 3 \\
1.3 E 5 \\
1.3 E 3 \\
6.7 E 3 \\
6.3 E 2 \\
3.1 E 2 \\
1.2 E 5\end{array}$ & $\begin{array}{l}3.4 \\
1.6 \\
1.6 \\
6.1 \\
1.3 \\
1.2 \\
1.7\end{array}$ & $\begin{array}{l}\text { 1.1E15 } \\
\text { 1. OE15 } \\
\text { 5.2E14 } \\
3.3 E 14 \\
3.0 E 14 \\
1.8 E 14 \\
9.4 E 13\end{array}$ & $\begin{array}{r}30 \\
29 \\
15 \\
9 \\
9 \\
5 \\
3\end{array}$ & $\begin{array}{l}3.6 E 15 \\
1.6 E 15 \\
8.6 E 14 \\
2.0 E 15 \\
3.9 E 14 \\
2.1 E 14 \\
1.6 E 14\end{array}$ & $\begin{array}{l}40 \\
18 \\
10 \\
23 \\
4 \\
2 \\
2\end{array}$ \\
\hline
\end{tabular}

(a) Oztunali and Roles 1986, Table D-7.

(b) Inventory after 5 years of cooling. ORIGEN2 (Croff 1980). See Appendix A.

(c) Percentage of contribution to the total dose.

Thus, the increase in burnup from 33 to $60 \mathrm{GWd} / \mathrm{t}$ could increase by $50 \%$ the risk associated with a major accident involving 5-year-old spent fuel. It should be noted that the effective doses listed in Table 3.7 are only calculated to find the major nuclide contributors and in no way represent the dose to an individual or population group from an actual accident, since release fractions or dilution factors were not included.

\subsection{SUMMARY OF ENVIRONMENTAL EFFECTS}

If leakage of radionuclides from a fuel element occurs during operation, the activity is expected to be removed by the plant cooling-water cleanup system. Thus, with extended burnup, little or no increase in the release of radionuclides to the environment is expected during normal operation. 0ther parts of the fuel cycle would also not be adversely affected by changing to an extended burnup fuel utilization plan. The impacts on workers and the general population would actually be reduced, because at higher burnups, outages for fuel changes would be less frequent and fuel shipments to and from the reactor sites would be reduced, thus reducing exposure. Although the inventory of long-lived radionuclides in the spent fuel would increase, the amount of spent fuel removed from reactors each year would decrease. Table 3.8 summarizes the impacts of normal operation.

Accidents that involve the damage or melting of the fuel in the reactor core and spent-fuel handling accidents were also reviewed. For accidents in which the core remains intact, involving only volatile fission products, no increases in impacts would occur, since the radionuclides contributing most to the dose are short-lived and, thus, do not increase with burnup. For more severe accidents, ones in which an appreciable amount or all of the fuel has melted and released from the containment system into the biosphere (Class 9), only a few fission products and the actinides would increase in inventory with increased burnup. The fission products would increase by no more than a factor of two; the actinides by no more than a factor of six (of those contributing to the dose). However, since these actinides have very small release fractions and biotransfer factors, risks would be insignificant compared to 
TABLE 3.8. Summary of Changes in Radiological Impacts for Various Fuel-Cycle Activities with the Implementation of Extended Burnup Fuel

\begin{tabular}{|c|c|c|c|}
\hline Activity & \% Change & Primary Contributors & Reference $^{(a)}$ \\
\hline Mining & -5 & Rn \& daughters & Table 3-11 \\
\hline Milling & -5 & $\begin{array}{l}\text { Ra-226, Th-230, U \& } \\
\text { daughters }\end{array}$ & Table 3-13 \\
\hline Conversion & -5 & $\begin{array}{l}\text { U \& daughters, Ra-226, } \\
\text { Th-230 }\end{array}$ & Table 3-14 \\
\hline Enrichment & 1 & U \& daughters & Table 3-15 \\
\hline Fabrication & -45 & Th-234, U \& daughters & Table 3-16 \\
\hline Refueling & -45 & & \\
\hline $\begin{array}{l}\text { Normal reactor } \\
\text { operation }\end{array}$ & $0^{(\mathrm{b})}$ & $\begin{array}{l}\text { Cs, tritium, I-131, } \\
\mathrm{Kr}, \mathrm{Sr}-90, \mathrm{Xe}\end{array}$ & $\begin{array}{l}\text { Table } 3.1 \text { of } \\
\text { this report }\end{array}$ \\
\hline $\begin{array}{l}\text { Transportation: } \\
\text { Fresh fuel } \\
\text { Spent fuel } \\
\text { Solid wastes }\end{array}$ & $\begin{array}{r}-45 \\
-45 \\
20\end{array}$ & $\begin{array}{l}U \\
\text { Fission products } \\
\text { Corrosion, activation, } \\
\quad \text { fission products }\end{array}$ & $\begin{array}{l}\text { Table } 4-3 \\
\text { Page } 4-4 \\
\text { Page } 4-19\end{array}$ \\
\hline Waste management & $\begin{array}{l}\text { See Table } \\
\quad 3.4\end{array}$ & & \\
\hline Reprocessing & -44 to -3 & $\begin{array}{l}\text { Tritium, } \mathrm{C}-14, \mathrm{Kr}-85, \mathrm{U}, \\
\text { I-129, I-133, Ru-106, } \\
\text { fission products, } \\
\text { transuranics }\end{array}$ & Table 3-24 \\
\hline
\end{tabular}

(a) Tables and pages referenced are from Mauro et al. 1985.

(b) There would be no change in the licensed technical specifications covering cooling water activity.

fission products such as cesium-137 and strontium-90. Furthermore, the factors of increases in the radioactive sources are less than the uncertainty involved in determining the overall risk to the public.

For the fuel-handling accident, only the noble gases and iodines escaping the damaged cladding are of significance in the assessment of dose impacts to workers involved. For a peak rod of a high-power fuel design at a burnup level of $60 \mathrm{GWd} / \mathrm{t}$, the release fractions only increase by a factor of three to four for these radionuclides (see Table 3.6); however, they remain below 
those assumed in Regulatory Guide 1.25, with the exception of iodine-131. Because the calculated iodine-131 gap-release fraction is $20 \%$ greater than the Regulatory Guide 1.25 (NRC 1972) assumed value of 0.10 , the calculated thyroid doses with extended burnup fuel resulting from a fuel-handling accident could be $20 \%$ higher than estimated using the guide.

Spent-fuel transportation accidents were reviewed. Activity inventory may increase by an overall factor of about three for long-lived radionuclides of concern (assuming a 5-year cooling period) when changing to extended burnup fuel. However, this increase would be offset by a decrease in the number of trips, such that the overall change would be a $50 \%$ increase in impact by changing to $60 \mathrm{GWd} / \mathrm{t}$ burnup. 


\subsection{ECONOMIC EFFECTS}

This chapter examines the economic effects of extending reactor fuel burnup. The scope of this investigation is limited to the directing costs of electricity production, and, accordingly, no attempt is made to estimate indirect costs or benefits by imputing dollar values to such factors as changes in radionuclide inventory, accident characteristics, or risk. It is assumed that where indirect effects are potentially large, changes in power-generating operations will be instituted and, therefore, will be reflected explicitly in direct costs.

In general, the expected overall economic effect of using extended burnup fuel would be a reduction in costs, resulting primarily from the reduction in the total volume of fuel required. Implementing extended burnup in commercial PWR and BWR plants would reduce the requirements for uranium and fuel processing and waste disposal. The resulting reduction in electricity production costs outweighs the associated cost increases in research and development and possible increases in waste storage. The principal finding is that extended burnup is expected to yield a net discounted cost savings on the order of $\$ 2$ billion. Most or all of this amount comes from the fuel production and other frontend activities of the fuel cycle.

In Section 4.1, problems concerning the available data are discussed, and problem-solving approaches are outlined. Section 4.2 addresses the front end of the fuel cycle and covers fuel-related research, fuel production and management, and aggregate front-end effects. Section 4.3 contains a discussion of the effects of high burnup fuel on the back end of the fuel cycle, including development and evaluation of waste management system activities, at-reactor storage of spent fuel, transport of spent fuel, repository storage, and waste repository costs. Section 4.4 summarizes the net economic effects over the total fuel cycle. The factors to which the economic results are most sensitive are discussed in Section 4.5 .

The analysis that follows is based on assumptions that were described in Chapter 1.0. These assumptions include projections of U.S. nuclear generating capacity (see Table 1.1), the projected implementation schedule for extended fuel burnup (see Table 1.2), and projections of the aggregate average burnup of spent fuel (see Table 1.4). Forecasts of spent-fuel discharges and average burnup levels (Table 1.5) were derived from these assumptions.

Table 4.1 provides an estimate of how the implementation of extended burnup will affect total spent-fuel discharges. [These values are based on the Weston (1985) data presented in Table 1.4.] In Table 4.1, the difference column shows for selected years the quantity reduction in spent fuel as a result of extended burnup; the ratio column presents the ratio of the quantity of spent fuel with extended burnup to the quantity of spent fuel without extended burnup. The indicated time pattern shows the benefits of extended burnup in terms of reduced amounts of spent fuel generated--increasing through about the year 2005, then declining until about 2010, and finally rising sharply through the end of the forecast period. 
IABLE 4.1. Comparisons of Forecasted Spent-Fuel Discharges With and Without Imp ementation of Extended Burnup by Year, $1985-2020$

\begin{tabular}{|c|c|c|}
\hline Year & $\begin{array}{l}\text { Difference, Extended } \\
\text { Burnup - No Extended } \\
\text { Burnup ( } t \text { uranium) } \\
\end{array}$ & $\begin{array}{l}\text { Ratio, Extended Burnup/ } \\
\text { No Extended Burnup }\end{array}$ \\
\hline $\begin{array}{l}1985 \\
1986 \\
1987 \\
1988 \\
1989 \\
1990 \\
1995 \\
2000 \\
2005 \\
2010 \\
2015 \\
2020\end{array}$ & $\begin{array}{r}-350 \\
-393 \\
-463 \\
-513 \\
-557 \\
-680 \\
-1,206 \\
-1,505 \\
-1,570 \\
-1,304 \\
-1,662 \\
-2,369\end{array}$ & $\begin{array}{l}0.720 \\
0.722 \\
0.719 \\
0.738 \\
0.736 \\
0.709 \\
0.559 \\
0.501 \\
0.544 \\
0.710 \\
0.613 \\
0.515\end{array}$ \\
\hline
\end{tabular}

(a) Derived from Weston 1985 (see Table 1.5 of this report).

\subsection{DATA}

The scope of this work encompasses the review, analysis, and synthesis of previously published materials. Accordingly, no attempt is made to develop and apply a new cost-estimating methodology for extended burnup or to rerun cost- estimating programs used by the various sources. This section relies most heavily on the following sources: Mauro et al. (1985), Franks and Geller (1986), Weston (1985), and Dippold and Wampler (1984).

With a few exceptions, this approach is adequate to develop a reasonably clear picture of the likely effects of extended burnup. Three principal difficulties were encountered, however. The first difficulty arose from the lack of detail in some of the available information. The second difficulty concerned discounting future costs to present values, and the third dealt with a recent revision in the DOE/EIA forecast of the middle-growth case of U.S. nuclear-generating capacity. Brief descriptions of our responses to these problems are described in the text, while the technical procedures that were applied to address them are contained in Appendix B of this report.

The first of these problems--the lack of detailed information--affects much of the front end of the fuel cycle. In particular, while some cost and other data are available for the separate stages of fuel production (mining, milling, conversion, enrichment, and fabrication), the detail is insufficient to estimate the effects of extended burnup on the individual stages. However, aggregated data do permit estimation of the cost effects for fuel production as a whole. 
The second problem concerned the discounting of future costs to the present. Throughout this report a $10 \%$ real discount rate is used. This rate is required by the U.S. Office of Management and Budget in the evaluation of time-distributed costs and benefits by agencies of the executive branch of the federal government (OMB 1972). However, several of the sources for this report (Weston 1985; Dippold and Wampler 1984; Murphie and Lang 1982) implicitly use a discount rate of zero when they derive aggregate costs and benefits by adding undiscounted future amounts. Another source (Franks and Geller 1986) uses a continuous discount rate of $7.813 \%$.

This cost issue is troublesome because the time profile of these amounts is not supplied by the source. The procedure used to deal with this problem was to start with information or assumptions about the time profile of the annual money amounts. Then the total amount reported by the source was "dediscounted" (recalculated without the discount) and disaggregated (see Glossary) back to a series of annual amounts.

The application of the above steps produced a set of estimated annual amounts that correspond to the original aggregated amount from the source. These amounts were next discounted at $10 \%$ and summed to arrive at a present value consistent with the analysis of the original source and a $10 \%$ discount rate.

For other figures with a similarly assumed time profile and original discount rate, repeating this entire procedure was unnecessary. The ratio of the adjusted present value to the original value yields a discount adjustment factor. Multiplying this factor by an original amount with a similar time profile and original discount rate gives the adjusted present value.

These discount adjustment factors vary according to how much the original discount rate differs from $10 \%$ and how far into the future the annual amounts are expected to occur. As an example, the Weston (1985) estimate of the cost savings in dry at-reactor storage from implementing extended burnup is $\$ 304$ million. Multiplying this amount by the discount adjustment factor of 0.1565 yields a discounted present value of $\$ 47.6$ million. However, the effects on the capital costs of the first repository occur mostly in earlier years. This effect is reflected in the greater discount adjustment factor of 0.4914 for these costs.

Depending largely on the assumptions concerning the time profile of the amounts, discount adjustment factors range from lows of 0.0356 for costs related to repository closure and 0.0777 for operations costs of the second repository to 0.4914 for the capital costs of the first repository.

The third major difficulty with the data provided by the primary sources is that they are based on an earlier DOE/EIA (1985) middle-growth forecast of U.S. nuclear generating capacity. The most recent middle-case forecast shows lower figures for nuclear generating capacity until the year 2005. After that year, the new forecast is higher than the old. The assumption that the aggregate effects of extended burnup are closely related to nationwide nuclear generating capacity implies that the more recent forecast shifts these effects 
into the more distant future. The discounted effect of the change in the forecast, therefore, is a reduction in the magnitude of the economic effects.

An estimate of the size of this reduction is developed by calculating the ratio of the discounted value of the new capacity figures to the discounted value of the old capacity figures. This procedure follows from the assumption that economic effects in any year are proportional to the nuclear capacity for that year. The result of this calculation is a factor of 0.9771 . This figure implies that the effect of the change in forecast is to reduce the expected present value of the economic effects of extended burnup by about 2.3\%. In terms of the general accuracy of forecasts and the uncertainty in the discounting adjustments, this figure is not highly significant, but suggests that the effect of using data based on different revisions of the capacity forecasts is relatively minor. Therefore, except where specifically noted, no adjustment is made for the most recent forecast.

\subsection{FRONT-END EFFECTS}

The primary source of information for front-end economic effects of extended burnup is the Franks and Geller (1986) report, The Benefit of Extended Burnup in Fuel cycle cost. The front end of the fuel cycle includes research and development expenditures on reactor fuel assemblies, fuel production, and burnup of the fuel in the reactor. Implementing high levels of extended burnup in commercial reactors may require additional fuel-related research expenditures.

Fuel production spans the operations of mining uranium ore, milling the ore to produce uranium oxide $\left(\mathrm{U}_{3} \mathrm{O}_{8}\right)$ or yellowcake, converting the yellowcake to uranium hexafluoride $\left(U_{6}\right)$, enriching the uranium by increasing the percentage of uranium-235, fabricating the fuel pellets and fuel-rod assemblies, and transporting the fuel to the reactor. During burnup of the fuel in the reactor, heat is used to generate steam, which in turn drives generators to produce electricity.

The primary economic effect of extended fuel burnup on the front end of the fuel cycle is a significant reduction in the amount of fuel required to generate an equivalent amount of electricity. The fuel requirements are reduced in direct relation to the increase in average burnup. Thus, cost is reduced because of the diminished amount of fuel required. However, there is an offsetting effect because the optimal enrichment of the fuel increases as the average burnup level increases. Generally, sources indicate that the cost reductions attributable to lessened fuel requirements will outweigh the additional expenditures for enrichment (Brown et al. 1986; Delene 1984; Franks and Geller 1986; Murphie and Lang 1982).

\subsubsection{Front-End Research}

While no insurmountable technological obstacles to extended burnup appear to exist, the attainment of batch average burnup levels of $60 \mathrm{GWd} / \mathrm{t}$ in commercial reactors will require, according to several sources, additional expenditures for research. For example, both Franks and Geller (1986, pp. 1-1, 3-6) and Roy F. Weston (1985, p. S-2) developed alternate sets of forecasts of 
burnup levels based on different assumptions regarding the level of DOE research funding. According to the Franks and Geller (1986, p. E-2) report:

DOE has estimated the costs for the research and development program to provide new support for extended burnup as $\$ 35$ million in asspent dollars. In discounted 1985 dollars at a continuous discount rate of $7.813 \%$ per year this equals $\$ 22.3$ million.

The schedule of these projected research expenditures is shown in Table 4.2. Using the same DOE figures, but a discount rate of $10 \%$ instead of $7.813 \%$, yields a 1985 present value of $\$ 21.3$ million.

\subsubsection{Fuel Production}

The primary source of information concerning front-end costs is Franks and Geller (1986). Because the effects are reported as an aggregate over the whole front end of the fuel cycle, the information is insufficient to quantify the effects of extended burnup on each stage of fuel production and on fuel management. However, some aspects of the stages of fuel production are useful in inferring the general direction and relative magnitude of the economic effects of an encompassing change, such as implementing extended burnup. In particular, other available sources indicate that the various stages of fuel production (mining, milling, conversion, enrichment, fabrication, transport) can be characterized by relatively constant per unit costs over any foreseeable range of output (e.g., Franks and Geller 1986, p. 2-4; and Brown et al. 1986, p. 7-85). The enrichment stage is an exception in that costs are a function of the level of enrichment as well as the volume of $U_{6}$, and the optimal enrichment level is higher with extended burnup.

TABLE 4.2. Projected DOE Research and Development Expenditures for New Extendegd) Burnup Projects by Year, 1987-1994 (d)

$\begin{array}{lc}\text { Year } & \begin{array}{c}\text { Expenditure } \\ \text { (millions of 1986\$) }\end{array} \\ 1987 & 6 \\ 1988 & 6 \\ 1989 & 3 \\ 1990 & 2 \\ 1991 & 3 \\ 1992 & 3 \\ 1993 & 6 \\ 1994 & 6 \\ & \\ \text { Source: Franks and Geller 1986, } \\ \text { (a) Projections from this source } \\ \text { do not extend beyond the } \\ \text { year 1994. }\end{array}$


This apparent absence of any significant economies or diseconomies of scale for most stages of fuel production is fortunate for our present purposes for two reasons. First, it implies that the economic effects on any stage are roughly proportional to the change in the output of the stage. Second, because the stages are all part of the same linear production stream, the output of each stage will change by the same proportion. (See Mauro et al. 1985, pp. 2-4 through 2-15.) In other words, ignoring any increased enrichment levels, the implication is that if fuel requirements decline by $10 \%$, a $10 \%$ decline in the output at each production stage will occur, and total fuel costs will decline by $10 \%$. This simplifies the analysis because the implementation schedule for extended burnup determines the amount of fuel to be produced, which in turn is proportional to costs. In practice, this relationship cannot be expected to hold rigidly. Further, we are not suggesting that prices are immune to change from other directions. In particular, reduced demand for fuel may result in prices being somewhat lower than they otherwise would be.

Another factor bearing on the level of fuel production is whether spent fuel is reprocessed. The extraction of some of the remaining uranium-235 from used fuel reduces the need for new fuel production. However, because there is currently no commercial reprocessing, nor is there likely to be, at least in the near term, it is assumed in this work that there will be no reprocessing. One source (Mauro et al. 1985), however, where relevant, provides two sets of data--one for the case with and one for the case without reprocessing. The reprocessing figures "are based on reprocessing of 35 MT of spent fuel per RRY [reference reactor year (see glossary)], at a burnup of 33,000 MWD/MT" (Mauro et al. 1985, p. 2-19).

\subsubsection{Mining}

A primary feature of and motivation for extended burnup is that it would reduce the amount of fuel required to produce a given amount of electricity. The diminished fuel requirements translate into a decrease in the amount of uranium ore required to be mined, as well as a decrease in milling, conversion, and fabrication required. Estimates vary as to the magnitude of the resulting decline in uranium mining. One source states that typically, extended burnup "is expected to reduce uranium mining and milling and $\mathrm{UF}_{6}$ production requirements by 14-15 percent" (DOE 1980a, p. 9). A similar estimate--a 15\% reduction in uranium resource requirements--is provided by Murphie and Lang (1982, p. 7-67). Even greater savings are reported by Brown et al. (1982). Brown and his coworkers indicate that employment of various optimizing measures could yield a potential reduction in uranium requirements on the order of $29 \%$ for the Browns Ferry Unit 3 BWR (Brown et al. 1986, pp. 7-71, 7-81).

In analyzing environmental impacts of extended burnup, another source, the Atomic Industrial Forum, Inc. (Mauro et al. 1985, pp. 3-13, 3-16), comes to a more conservative conclusion. This source suggests that as the burnup level is increased, the environmental impacts associated with mining decrease in an asymptotic fashion (i.e., the rate of decrease lessens with increasing burnup). At the upper end of the range, an increase in burnup from 55 to 60 GWd/t would result in no change in environmental impact from mining. Over the whole range from 33 to $60 \mathrm{GWd} / t$, there would be a $5 \%$ decrease in impacts. 
This conclusion follows from estimates of how a reactor's yearly requirements for uranium ore would change as average burnup is increased from 33 to 60 GWd/t. Table 4.3 shows estimated uranium ore requirements for an RRY. RRY figures are intentionally high to ensure a conservative bias when estimating prospective environmental and other impacts.

\subsubsection{Milling}

In the milling stage of fuel production, uranium ore is processed into a more concentrated form called yellowcake (see Glossary). With extended fuel burnup, milling requirements would decline along with other stages of fuel production and would also depend on whether spent fuel is reprocessed. Table 4.4 provides estimated RRY milling requirements in tonnes of yellowcake. In analyzing the economic effects of extended burnup on the front end of the fuel cycle, the Franks and Geller report used unit costs, as indicated in Table 4.5.

\subsubsection{Conversion}

The procedure for converting yellowcake to $\mathrm{UF}_{6}$ is a straightforward chemical process, the output of which is closely proportional to the input (Mauro et al. 1985, pp. 2-13,6-7). Estimated conversion work generally decreases at a decreasing rate with increases in the burnup level.

Table 4.6 shows forecasts of conversion costs used in the Franks and Geller report. These figures were developed in a manner similar to those in Table 4.5.

TABLE 4.3. Annualized Reference Reactor Year Uranium Ore Requirements With and Without Reprocessing, by Burnup Level

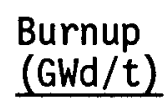

33

35

40

45

50

55

60

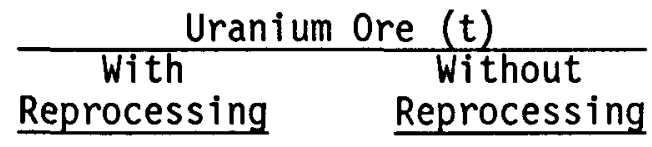

280

273

241

237

236

234

234

Source: Mauro et al. 1985, p. 3-14. Uranium ore requirements without reprocessing were calculated from yellowcake requirements with reprocessing using the Mauro et al. assumption of a constant yellowcake-to-ore ratio of 0.9 . 
TABLE 4.4. Annualized Reference Reactor Year Milling Requirements With and Without Reprocessing, by Burnup Level

$\frac{\text { Burnup Level }}{(\text { GWd } / \mathrm{t})}$

33

35

40

45

50

55

60

$\begin{array}{cc}\text { Yellowcake }(t) \\ \text { With } & \text { Without } \\ \text { Reprocessing } & \text { Reprocessing }\end{array}$

200

199

195

192

191

190

190
252

246

233

225

219

215

212

Source: Mauro et al. 1985, Tables 3-11 and 3-18.

TABLE 4.5. Forecasted Milling Costs

by Year, 1985-2000

$\begin{array}{cc}\text { Year } & \begin{array}{c}\text { Yellowcake } \\ \text { Cost } \\ (1985 \$ / 1 b)\end{array} \\ 1985 & 30.50 \\ 1990 & 44.20 \\ 1995 & 51.60 \\ 2000 & 51.60\end{array}$

Source: Franks and Geller 1986, Table 2-1.

TABLE 4.6. Forecasted Conversion Costs by Year, 1985-2000 (1985\$/kg UF 6$)$

\begin{tabular}{|c|c|}
\hline Year & Cost \\
\hline $\begin{array}{l}1985 \\
1990 \\
1995 \\
2000\end{array}$ & $\begin{array}{l}7.40 \\
7.40 \\
7.40 \\
9.50\end{array}$ \\
\hline
\end{tabular}

Source: Franks and Geller 1986, Table 2-1. 


\subsubsection{Enrichment}

Fuel enrichment involves increasing the proportion of uranium-235 in the fuel. As Weston (1985, p. 3-4) states:

Enrichment is the initial proportion of fissile uranium in the fuel. The higher the burnup desired from nuclear fuel, the higher the required enrichment. Normal enrichment for reactors is about 3.5 percent, and the ... NRC limit $\{$ fuel manufacturers to producing fuel with no more than 5 percent enrichment for PWRs. As the fuel undergoes fission reactions in the reactor, the enrichment diminishes.

The consequent increase in separative work necessary to achieve these higher enrichment levels is illustrated in Table 4.7. The figures shown here are for an RRY, which means that they reflect the maximum levels likely to occur, since they were developed to estimate environmental effects.

The prospect of new methods of fuel enrichment opens the possibility of significant reductions in cost in future years. According to Delene (1984, p. 2-5):

The current enrichment price is $\$ 135 /$ SWU [separative work unit]. This price will escalate at approximately the rate of inflation under current rules. However the advent of the advanced centrifuges and the laser isotope separation has the prospect of considerably lowering separative work costs. DOE projections show SWU prices declining to $\$ 70-100 /$ SWU by the year 2000 due to these advanced technologies.

TABLE 4.7. Annualized Reference Reactor Year Separative Work Unit Requirements With and Without Uranium Reprocessing, by Burnup Level

\section{Burnup Leve1 $(\mathrm{GWd} / \mathrm{t})$}

33

35

40

45

50

55

60
Separative Work Units

\begin{tabular}{cc}
\hline With & Without \\
Reprocessing & Reprocessing
\end{tabular}

134

134

133

132

132

134

135
140

138

135

133

133

133

134

Source: Mauro et al. 1985, Tables 3-11 and 3-18.

[a] Note that 10 CFR 51.52 limits enrichment to $4 \%$ by weight, rather than the $5 \%$ stated by Weston (1985). 
The Franks and Geller (1986) report takes a conservative approach in estimating front-end economic effects of extended burnup. A constant cost of \$135 per SWU is assumed for all years.

\subsubsection{Fabrication}

Extended burnup poses some possible technical problems with fabrication. Fuel assemblies must be able to be retained in the reactor core for longer periods without failure. Principal concerns are increases in pressure in the fuel rods caused by the release of fission gases, cladding corrosion, fuelpellet expansion, and fuel-rod integrity. Because of these technical concerns, most sources anticipate that fuel-pellet and fuel-rod assembly operations will experience an increase in cost.

According to the Franks and Geller report (1986, pp. 4-5, 4-6):

Increases in fuel burnup may require technical modifications to the fuel designs that increase fabrication costs. . . Because of possible increased fabrication costs, two cost schedules were used. In the first the cost was kept constant at $\$ 230 / \mathrm{kgU}$; in the second, it was allowed to increase with target discharge burnup.

Franks and Geller estimated a cost of $\$ 245$ per $\mathrm{kg}$ of uranium for PWR fuel designed to undergo burnup levels in the over-40- and up-to-50-GWd/t range. Above this level, the estimated cost is $\$ 273$ per $\mathrm{kg}$ of uranium. Franks and Geller also estimated a cost of $\$ 265$ per $\mathrm{kg}$ of uranium for BWR fuel for burnups above 33 and up to $45 \mathrm{GWd} / \mathrm{t}$.

This pattern of cost increases is confirmed by Delene (1984, p. 5):

Extended burnup fuel fabrication costs are assumed to cost from 10-25\% more than that for standard fuel. For the purposes of this study, extended fuel burnup reference fabrication costs are assumed to increase by $1 \%$ over the reference standard fuel fabrication cost for each $\mathrm{MWd} / \mathrm{kg}$ the fuel exceeds $30 \mathrm{MWd} / \mathrm{kg}$.

The price level for fuel fabrication to be used at the $60 \mathrm{GWd} / \mathrm{t}$ burnup level implied by Delene is higher than that indicated by Franks and Geller--\$299 per $\mathrm{kg}$ versus $\$ 273$ per $\mathrm{kg}$ of uranium.

Offsetting the increased per unit price of fuel fabrication is the decrease in the amount of fuel required at higher burnup levels. This reduction in terms of RRY requirements is shown in Table 4.8 .

Applying the escalating Franks and Geller PWR fuel fabrication price schedule to the fuel requirements in Table 4.8 gives an annual (RRY) fuel fabrication cost of about $\$ 8.1$ million at a burnup level of $33 \mathrm{GWd} / \mathrm{t}$. For a burnup of $60 \mathrm{GWd} / t$, the annual fuel fabrication cost would decline by nearly $\$ 3$ million to $\$ 5.3$ million, which is a decline of nearly $35 \%$. Performing the same calculations using the fuel fabrication price increase suggested by Delene, the annual fuel fabrication cost per RRY would be about $\$ 2.3$ million to about $\$ 5.8 \mathrm{million}$. 
TABLE 4.8. Annualized Reference Reactor Year Fuel Requirements by Burnup Leve1

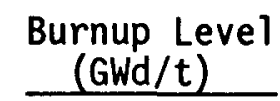

33

35

40

45

50

55

60
Fuel Mass

(t)

$$
\begin{aligned}
& 35.0 \\
& 33.0 \\
& 28.9 \\
& 25.7 \\
& 23.1 \\
& 21.0 \\
& 19.3
\end{aligned}
$$

Source: Mauro et al. 1985, Table 3-11.

\subsubsection{Transportation}

The decrease in required fuel mass as a result of implementing extended burnup would translate directly into reduced transportation requirements as shown in Table 4.9.

TABLE 4.9. Annualized Reference Reactor Year Transportation

Requirements for Unirradiated Fuel, by Burnup Level

$$
\begin{array}{cl}
\begin{array}{c}
\text { Burnup Leve } 1 \\
(\mathrm{GWd} / \mathrm{t})
\end{array} & \begin{array}{l}
\text { Number of } \\
\text { Truckloads }
\end{array} \\
\hline
\end{array}
$$

$\begin{array}{ll}33 & 6 \\ 35 & 6 \\ 40 & 5 \\ 45 & 5 \\ 50 & 4 \\ 55 & 4 \\ 60 & 4\end{array}$

Source: Mauro et al. 1985, Table 4-2.

\subsubsection{Fuel Management}

Based on fuel-management considerations alone, there would be savings from using extended burnup fuels (Delene 1984, p. 1). Extended burnup can be achieved either by extending the time between refuelings or by increasing the number of batches while maintaining annual refueling.

At a burnup of about $30 \mathrm{MWd} / \mathrm{kg}$, a standard fuel batch stays in the core for 3 cycles so there are 3 batches in the core at one time. . - Alternatively, the number of batches in the core can be held 
constant and the cycle time increased. This latter case leads to higher fuel enrichments as fuel burnup is increased than the case where the cycle length is held constant. The longer cycle length offers other advantages such as increased reactor availability brought about by the decreased number of shutdowns for refueling [Delene 1984, p. 7].

\subsubsection{Aggregate Front-End Effects}

Franks and Geller (1986) calculated the 1985 present value of front-end cost savings through the year 2020 as $\$ 500$ million. This figure reflects costs resulting from DOE-funded research for the DOE/EIA (1985) middle-growth forecast of nuclear generating capacity. For the no-new-orders forecast, the estimated cost reductions amount to $\$ 490$ million.

Unfortunately, while these Franks and Geller figures are the best available figures for front-end cost estimates of extended burnup, they are inconsistent with others in the current DOE/EIA report. First, the Franks and Geller estimates were calculated using a discount rate of $7.813 \%$ rather than $10 \%$, as in the DOE/EIA report. Second, recent revisions in the DOE/EIA middle-growth forecasts are not reflected in Franks and Geller's estimates. Third, Franks and Geller adopted the convention of including at-reactor storage in the front end, and, therefore, the totals should have these costs subtracted. The last and most significant problem with the Franks and Geller cost estimates is that they incorporate a different pair of scenarios than the one with which this work is concerned. Franks and Geller calculated the net cost savings of extended burnup with additional DOE-funded research versus extended burnup without this research. Of interest here, however, is extended burnup (with additional DOE-funded research) versus no extended burnup.

While the Franks and Geller report provides a description of the methods used, intermediate results are not supplied. In particular, no time pattern of costs or cost savings is given. Therefore, any adjustments are, to some extent, necessarily crude. A detailed description of the method used to adjust these data to a $10 \%$ discount rate and to adjust for revisions in the DOE/EIA forecasts is given in Appendix B, Section B.1.

Applying the process described in Appendix B, Section B.1 gives an estimated cost savings of $\$ 2.6$ billion for the years 1985 through 2020 . This amount is substantially higher than that estimated by Franks and Geller because 1) our schedule of extended burnup implementation assumes higher average burnup levels than Franks and Geller's levels, and 2) the base-case burnup levels used here are constant, whereas Franks and Geller's levels increase over time.

Two simple adjustments remained. The first was to eliminate the cost of at-reactor storage. As noted below, the adjusted Weston (1985) estimate of atreactor storage costs converted to 1985 dollars is $\$ 47.6$ million. Second, the cost savings needed to be reduced by the cost of the DOE-funded research, which was calculated above at $\$ 21.3$ million. Subtracting these amounts yields a net cost savings of $\$ 2.53$ billion for the front end of the fuel cycle. 


\subsection{BACK-END EFFECTS}

In this work, "back-end" refers to those stages of the fuel cycle starting with discharge from the reactor core through final repository storage. Also included are the development and evaluation related to these stages. The cost effects of extended burnup on these stages of the fuel cycle are described in this section.

Extending fuel burnup changes the composition of radioactive isotopes in the spent fuel, which in turn causes a change in the thermal and radiation characteristics of the fuel. The increased neutron activity of the waste may require more extensive shielding. If this is so, the capacity of the spent fuel transport casks may need to be reduced, and thus, the number of casks and waste shipments may need to be increased. Increased costs for these operations on a per-cask basis would result. The increased heat discharged by the extended burnup spent fuel may necessitate greater spacing between fuel casks in the repository, implying a greater repository cost per fuel cask.

Extended burnup generates a smaller volume of waste than current burnup levels, which would offset the cost increases described above. The total radioactivity per unit of power generated (i.e., the number of curies) that is processed in the repository would remain unaffected by extended fuel burnup (Weston 1985, p. 2-19). Therefore, while the increased radioactivity and increased heat discharge would result in higher costs per cask, fewer casks would be needed.

\subsubsection{Development and Evaluation}

Development and evaluation (D\&E) consist of all siting, design, development, testing, regulatory, and institutional activities associated with the waste-management system and account for a major portion of the total system costs. Despite the size of this cost category, various sources indicate that extended burnup would have no significant effect on the level of costs: "D\&E costs are considered to be only minimally affected by changes in burnup" (DOE $1985 a$, p. 10). "The D\&E costs represent about one-third of the cost of the total waste-management system. . . However, the D\&E costs are not expected to be significantly affected by extended fuel burnup" (Weston 1985, p. 1-5).

\subsubsection{At-Reactor Storage}

The Weston (1985) report estimates dry at-reactor storage (DRS) costs at $\$ 720$ million for the DOE/EIA middle-case forecast with no increase in burnup (see Table 1.1 and accompanying discussion). At an average burnup level of $60 \mathrm{GWd} / t$, estimated DRS costs would decrease to $\$ 420 \mathrm{million}$. Expressed in 1985 dollars, these amounts are $\$ 729$ million and $\$ 425$ million, respectively, with a difference of $\$ 304$ million. For alternative assumptions about the rate of implementation of extended burnup, Weston found that cost reductions for DRS "are nearly proportional to the decrease in spent-fuel generation rates" (Weston 1985, p. 4-21). 
Whereas Weston is unclear regarding the discounting procedure, his figures appear to be calculated as sums of undiscounted annual amounts. Unfortunately, Weston does not give the actual costs over time for different burnup levels, so it is difficuit to interpret his figures. However, a rough approximation of the discounted value of the cost savings can be made by applying the methodology outlined in Section 4.1. Cost savings over time were estimated from a graph showing levels of required dry at-reactor storage by year and burnup level (Weston 1985, p. 3-7). The calculated discount adjustment factor is 0.1565. By multiplying this factor by $\$ 304$ million, an estimated present value of $\$ 47.6$ million in cost savings for at-reactor storage was reached. The reason the discount adjustment factor is so small is that the savings in this cost category do not begin until 1991, and the peak savings do not occur until 2004.

\subsubsection{Transportation}

Following temporary storage at the reactor site, spent fuel would be transported to one of two nuclear waste repositories for final disposal. The spent fuel would be shipped in special casks designed to meet requirements of radiation shielding and heat dissipation. These casks would be a major component of transportation costs.

The shielding and heat dissipation requirements per unit mass of spent fuel increase with higher burnup levels. However, the higher burnup levels also result in a reduction in the amount of fuel discharged per unit of electricity generated. Increased duration of at-reactor storage permits the waste to cool and become less radioactive, thereby complying with the transportation-cask minimum specifications.

Different authors have different views as to how cask volume will be affected by extended burnup. According to a DOE study (DOE 1985a, p. 7),

Generally, the currently available transportation casks could carry extended burnup fuel at their design capacity, unless limited by criticality concerns. - . The Nuclear Regulatory Commission requires that transportation cask capacities be determined under the assumption that the fuel to be transported is fresh unirradiated fuel. This may result in reduced cask capacity.

Dippold and Wampler found that cask volume, as part of a joint transportation and repository optimization analysis, would decrease with extended burnup (Dippold and Wampler 1984, p. 33 and Table 6, p. 37). Weston's principal finding concerning back-end transportation (Weston 1985, p. S-13) was that the

reduction in the quantity of spent fuel results in a commensurate reduction in transportation costs because transportation-cask capacities are generally not affected by extended-burnup fuel. Therefore, transportation costs show a downward trend with increasing burnup.

Two sets of cost estimates on the effects of extended burnup on back-end transportation costs are available. Table 4.10 summarizes the Weston (1985) estimates of total back-end transportation costs for different burnup levels 
TABLE 4.10. Back-End Transportation Costs, 1984-2020, by Repository Type and Burnup Level

(millions of 1985\$, undiscounted)

\begin{tabular}{|c|c|c|c|}
\hline \multirow[b]{2}{*}{ Burnup Level } & \multicolumn{3}{|c|}{ Repository Type } \\
\hline & $\begin{array}{c}\text { Salt } \\
\text { and } \\
\text { Granite } \\
\end{array}$ & $\begin{array}{c}\text { Tuff } \\
\text { and } \\
\text { Granite } \\
\end{array}$ & $\begin{array}{l}\text { Basalt } \\
\text { and } \\
\text { Granite } \\
\end{array}$ \\
\hline $\begin{array}{l}33 \mathrm{GWd} / \mathrm{t}: \\
\text { Capital } \\
\text { Operation }\end{array}$ & $\begin{array}{r}424 \\
1,657 \\
\end{array}$ & $\begin{array}{r}461 \\
2,003 \\
\end{array}$ & $\begin{array}{r}468 \\
2,062 \\
\end{array}$ \\
\hline TOTAL & 2,081 & 2,464 & 2,530 \\
\hline $\begin{array}{l}60 \mathrm{GWd} / \mathrm{t}: \\
\text { Capital } \\
\text { Operation }\end{array}$ & $\begin{array}{r}271 \\
1,119 \\
\end{array}$ & $\begin{array}{r}298 \\
1,329 \\
\end{array}$ & $\begin{array}{r}302 \\
1,371 \\
\end{array}$ \\
\hline TOTAL & 1,350 & 1,626 & 1,673 \\
\hline $\begin{array}{l}\text { Cost Difference: } \\
\text { Capital } \\
\text { Operation }\end{array}$ & $\begin{array}{l}153 \\
538 \\
\end{array}$ & $\begin{array}{l}163 \\
674 \\
\end{array}$ & $\begin{array}{l}166 \\
691 \\
\end{array}$ \\
\hline TOTAL & 731 & 838 & 857 \\
\hline $\begin{array}{l}\text { Percent Decrease: } \\
\text { Capital } \\
\text { Operation }\end{array}$ & $\begin{array}{l}36.1 \\
32.5 \\
\end{array}$ & $\begin{array}{r}35.4 \\
33.6 \\
\end{array}$ & $\begin{array}{r}35.5 \\
33.5 \\
\end{array}$ \\
\hline TOTAL & 35.1 & 34.0 & 33.9 \\
\hline
\end{tabular}
Source: Weston 1985, pp. 4-11, 4-13, 4-15. Costs expressed in 1984\$ in original source were converted to $1985 \$$ using the gross national product (GNP) implicit price deflator. Data are consistent with DOE/EIA middle-growth case.

and for different repository types. The total back-end transportation costs are broken down into capital and operation categories. Capital includes "spentfuel assemblies" or shipping casks. Operation costs are composed of cask hauling, cask maintenance, and traffic management. Weston assumes that, "consistent with the ... Mission Plan [DOE 1985b], there are two regional repositories, one in the east and one in the west, and all spent fuel is sent to one of these repositories. . . [The] eastern repository is assumed to be in crystalline rock (granite)" (Weston 1985, pp. 3-1 to 3-2). The western repository is assumed to be in either salt, tuff, or basalt formations. Because repositories of different geological type would be located in different parts 
of the country, estimated shipping distances and, therefore, estimated transportation costs would differ by repository type. The age of the spent fuel is assumed to be at least 5 years (Weston 1985, p. 3-1).

Table 4.11 presents a set of estimates for back-end transportation costs developed by Dippold and Wampler (1984). The capital and operation cost categories are the same as in the Weston data. The lower costs associated with higher burnup levels in both the Weston and the Dippold and Wampler estimates result almost entirely from the need for fewer shipments as less spent fuel is discharged from reactors.

It is clear that there is a substantial difference in the magnitude of the costs and the cost savings estimated by these two sources. This discrepancy exists even though both estimate sets were generated with versions of the

TABLE 4.11. Estimated Back-End Transportation Costs, 1984-2020, by Spent-Fuel Age and Burnup Level (millions of 1985\$, undiscounted)

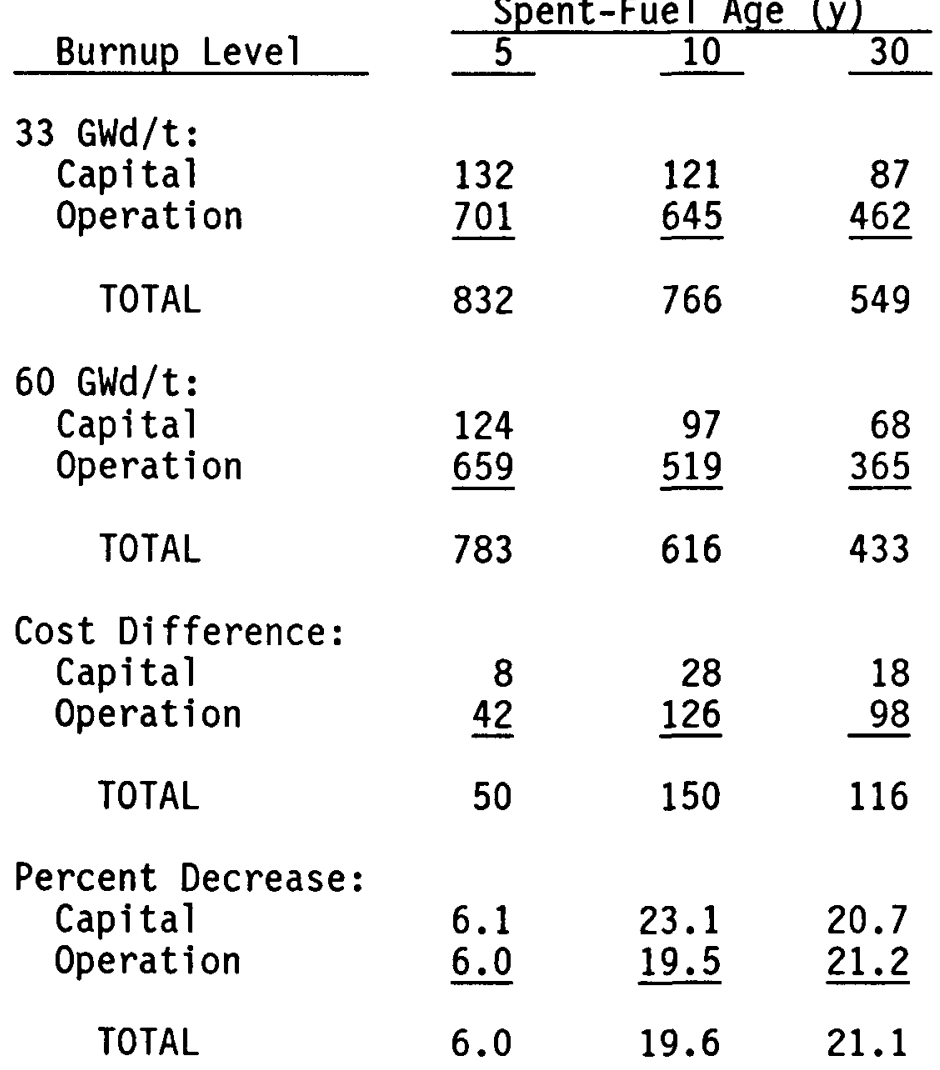

Source: Dippold and Wampler 1984, Appendix B, pp. 63 to 87 . Costs expressed in $1983 \$$ in original source were converted to $1985 \$$ using GNP implicit price deflator. 
same computer program, WADCOM (WAste Disposal COst Model) (Weston 1985, p. 4-4; Dippold and Wampler 1984, pp. 19-21). Weston used the multiple facilities version (WADCOM-MF), while Dippold and Wampler used a version consistent with their assumption of a single salt repository. The principal reason for the different cost figures in the two reports appears to be the assumed rates at which the repository or repositories are designed to receive spent fuel.

For the assumed single salt repository, Dippold and Wampler use a design receipt rate that is optimized for the reduced fuel stream from implementation of extended burnup. Thus, for a burnup level of $33 \mathrm{GWd} / \mathrm{t}$, the design receipt rate is $3,000 \mathrm{t} / \mathrm{y}$; for a burnup level of $50 \mathrm{GWd} / \mathrm{t}$, the design receipt rate is $1,980 \mathrm{t} / \mathrm{y}_{i}$ and for a burnup level of $60 \mathrm{GWd} / \mathrm{t}$, the design receipt rate is $1,650 \mathrm{t} / \mathrm{y}$ (Dippold and Wampler 1984, Appendix $B, \mathrm{pp} .63$ to 87 ). In contrast, the Weston report assumes that the receipt rates at each of two repositories conform to the specifications of the Mission Plan (DOE 1985b). Accordingly, design recelpt rates for each of the two repositories rise in steps over time to a maximum of $3,000 \mathrm{t} / \mathrm{y}$, making the maximum total design receipt rate $6,000 \mathrm{t} / \mathrm{y}$ (Weston 1985, p. 1-4).

At a burnup level of $60 \mathrm{GWd} / \mathrm{t}$, the design receipt rates assumed by Weston are from 2.2 to 3.6 times higher than those assumed by Dippold and Wampler. This is roughly equivalent to the ratio of their respective estimates of transportation costs for a given burnup level, indicating that the difference in the cost estimates is largely due to the difference in assumed design receipt rates.

Another indication of the decline in transportation activity associated with increases in burnup levels is provided by another source, as shown in Table 4.12 .

It is necessary to adjust the Weston and the Dippold and Wampler data from undiscounted sums of annual amounts to a 1985 present value calculated using a $10 \%$ discount rate. The procedure for accomplishing this is described in Appendix B, Section B.2. After adjustment, the 1985 present value estimates of the Weston transportation cost savings are $\$ 61.8 \mathrm{million}, \$ 70.8 \mathrm{million}$, and $\$ 72.4$ million for salt and granite, tuff and granite, and basalt and granite repositories, respectively. Applying the same adjustment to the Dippold and Wampler data yields estimates of the 1985 present value of transportation cost savings of $\$ 4.2$ million, $\$ 12.7$ million, and $\$ 9.8$ million for spent fuel aged 5, 10, and 30 years, respectively. Again, these differences reflect different assumptions concerning repository design rates.

It is difficult to choose between these sets of estimates. First, it is unclear whether one or two repositories will be built. In addition, the repository type(s) is not yet known, nor is the design receipt rate(s). Also, it should be noted that in order to reduce the inventory backlog of spent fuel, the total design receipt rate will have to exceed the total fuel discharge rate. For these reasons, we view the Weston and the Dippold and Wampler data as indicating the range of reasonable outcomes. 
TABLE 4.12. Annualized Reference Reactor Year Transportation Requirements for Spent Fuel, by Burnup Level

$\underset{\substack{\text { Burnup Level } \\(\mathrm{GWd} / \mathrm{t})}}{ }$

33

35

40

45

50

55

60
Number of Shipments per Reactor Year

Truck Rail Barge ${ }^{(a)}$

\section{0}

57

50

44

40

36

33

10
10
9
8
7
6
6

5

5

5

4

4

3

3

Source: Mauro et al. 1985, Table 4-5.

(a) No commercial cask currently exists for barges.

\subsubsection{Repository Storage}

Extended burnup results in spent fuel with greater radioactivity and greater heat dissipation requirements per unit mass, but with fewer tonnes per kilowatt hour of electricity generated. As a result, though extended burnup reduces the number of assemblies, or quantity of spent fuel, the areas of the repositories are still about the same size as that required for present burnup levels because the total decay heat dissipation requirements remain about the same based on the integrated fuel exposure or energy extraction (DOE 1985a). Consequently, the analysis "indicates that the repository costs for all systems remain about the same as burnup increases if non integral [sic] waste package loading is assumed" (DOE 1985a, p. 9).

A more optimistic conclusion is presented in the Dippold and Wampler (1984) report. Here, repository costs are found to decline continuously as burnup is increased from $33 \mathrm{GWd} / \mathrm{t}$ to $60 \mathrm{GWd} / \mathrm{t}$ and as spent fuel age is increased from 5 to 30 years. These results are presented in Table 4.13.

Two qualifications must be applied to the costs shown in Table 4.13, however. The first is that these results are calculated on the assumption that all spent fuel will have the same burnup level. This assumption is not realistic because optimal burnup will differ among reactors, and effective burnup levels will differ among different fuel assemblies within the same fuel batch. The second qualification is that the dollar amounts shown are simple summations of a sequence of annual costs extending to the year 2020. Another set of repository cost estimates (from Weston 1985) is presented in Table 4.14. These costs are also totals of undiscounted annual amounts. Estimating the discounted present value of both these sets of costs is discussed in Appendix B, Section B.3.

Table 4.15 presents the resulting estimates of the present value of the Dippold and Wampler repository costs. As expected, these figures imply that repository costs decline with spent-fuel age. This reduction occurs because

$$
\text { 4-18 }
$$


TABLE 4.13. Total Undiscounted Repository Cost by Spent-Fuel Age and Burnup Level (millions of 1985\$)

Burnup Level (GWd/t)

\begin{tabular}{lcc}
\multicolumn{3}{c}{ Spent-Fuel Age $(y)$} \\
\hline 5 & 10 & \\
5,310 & 5,134 & \\
4,995 & 4,777 & 4,867 \\
4,926 & 4,697 & 4,479 \\
& & 4,405
\end{tabular}

Source: Dippold and Wampler 1984, Appendix B, pp. 63-87. Costs expressed in 1983\$ in original source were converted to $1985 \$$ using the GNP implicit price deflator.

(a) Total includes waste preparation and repository costs, but excludes at-reactor storage costs.

TABLE 4.14. Repository Costs, 1984-2020, by Burnup Level and Repository Type (millions of $1985 \$$, undiscounted)

Repository Type

Salt

Granite

TOTAL

Tuff

Granite

TOTAL

Basalt

Granite

TOTAL

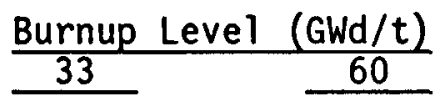

6,573

5,786

7,455

6,945

12,359

14,400

6,719

5,786

8,649

$\underline{6,945}$

12,505

15,594

8,584

5,786

9,347

6,945

14,370

16,292

Source: Weston 1985, pp. 4-11, 4-13, 4-15. Costs expressed in 1984\$ in the original source were converted to $1985 \$$ using the GNP implicit price deflator. Data are consistent with the DOE/EIA middle-growth case (see Table 1.1 and accompanying discussion). 
TABLE 4.15. Total Discounted Repository Costs by Spent-Fuel Age and Burnup Level (a) (millions of 1985\$)

\begin{tabular}{|c|c|c|c|}
\hline \multirow{2}{*}{$\begin{array}{c}\text { Burnup Leve1 } \\
(\mathrm{GWd} / \mathrm{t})\end{array}$} & \multicolumn{3}{|c|}{ Spent Fuel Age (y) } \\
\hline & 5 & 10 & 30 \\
\hline $\begin{array}{l}33 \\
50 \\
60\end{array}$ & $\begin{array}{l}1081 \\
1017 \\
1003\end{array}$ & $\begin{array}{r}1045 \\
972 \\
956\end{array}$ & $\begin{array}{l}991 \\
912 \\
896\end{array}$ \\
\hline $\begin{array}{l}\text { Difference } \\
(33-60)\end{array}$ & 78 & 89 & 94 \\
\hline
\end{tabular}

Source: Derived from Dippold and Wampler 1984.

(a) Total includes waste preparation and repository costs, but excludes at-reactor storage costs.

the shielding and heat dissipation requirements are reduced for fuel that has been stored at the reactor for longer periods. Note that repository costs decline with an increase in burnup level.

Table 4.16 shows the Weston cost estimates adjusted to 1985 present values. These figures and the data derived from the Dippold and Wampler information imply different conclusions. Here the effects of increased burnup levels

TABLE 4.16. Estimated Discounted Repository Costs, 1984-2020, by Burnup Level and Repository Type (millions of 1985\$)

\begin{tabular}{|c|c|c|c|}
\hline Repository Type & $\frac{\text { Burnup }}{33}$ & $\frac{\text { Level (GWd/t) }}{60}$ & $\begin{array}{c}\text { Difference } \\
(33-60) \\
\end{array}$ \\
\hline $\begin{array}{l}\text { Salt } \\
\text { Granite }\end{array}$ & $\begin{array}{l}1,568 \\
1,024 \\
\end{array}$ & $\begin{array}{l}1,778 \\
1,229 \\
\end{array}$ & $\begin{array}{l}-210 \\
-205 \\
\end{array}$ \\
\hline TOTAL & 2,592 & 3,007 & -415 \\
\hline $\begin{array}{l}\text { Tuff } \\
\text { Granite }\end{array}$ & $\begin{array}{l}1,602 \\
1,024 \\
\end{array}$ & $\begin{array}{l}2,063 \\
1,229 \\
\end{array}$ & $\begin{array}{l}-461 \\
-205 \\
\end{array}$ \\
\hline TOTAL & 2,626 & 3,292 & -666 \\
\hline $\begin{array}{l}\text { Basalt } \\
\text { Granite }\end{array}$ & $\begin{array}{l}2,047 \\
1,024 \\
\end{array}$ & $\begin{array}{l}2,229 \\
1,229 \\
\end{array}$ & $\begin{array}{l}-182 \\
-205 \\
\end{array}$ \\
\hline TOTAL & 3,071 & 3,458 & -387 \\
\hline
\end{tabular}

Source: Derived from Weston 1985. 
increase repository costs. However, a closer review of the source reveals that no monotonic trend in costs occurs between the 33 and $60 \mathrm{GWd} / \mathrm{t}$ burnup levels. The burnup level at which repository costs are at a minimum depends on the type of repository; but in all cases analyzed the minimum level occurs at burnup levels above $33 \mathrm{GWd} / \mathrm{t}$. Weston explains these results as follows (Weston 1985, pp. S-11 to S-13):

For repositories, the primary effect of extended burnup is a reduction in the capacities of the waste packages because of the increased heat-generation rate per tonne of the fuel. When the heat-generation rate per package is treated as a constraint, the number of spentfuel assemblies that can be loaded in a waste package must be reduced to accommodate extended-burnup fuel. . .

The underground area required for the disposal of the spent fuel depends on the heat output of the total spent-fuel inventory, rather than the total weight. Therefore, though the extended-burnup scenarios show significant reduction in the quantity of spent fuel, the areal sizes of the repositories will be equivalent to or greater than those required for the base-burnup scenario [no extended burnup] because of the increased heat-generation rate per metric ton of uranium.

In addition, Weston suggests that the reason for the divergence of his estimates from those of Dippold and Wampler is that they did not assume that all spent fuel would have the same burnup level (Weston 1985, p. S-13):

This range in burnups does not allow the optimization of repository designs for a single burnup level. Therefore, realistic repository cost savings associated with extended burnup will be less than those for a repository optimized for a single burnup level, such as those presented in a recent report by [Dippold and Wampler].

\subsubsection{Back-End Total Costs}

Table 4.17 summarizes the foregoing estimates of back-end cost savings resulting from implementing extended burnup. Figures derived from both the Weston and the Dippold and Wampler data are shown. Because Dippold and Wampler do not provide an estimate of at-reactor storage costs, the Weston-based figure is inserted to allow calculation of total back-end cost savings.

The totals for the two sources are quite different. The Weston data led to an estimated net cost increase of from $\$ 267$ to $\$ 548$ million. In contrast, the estimates generated from the Dippold and Wampler figures show cost savings in the range of $\$ 130$ to a little over $\$ 150$ million. Clearly, the Weston figures span a much larger range than the others. The differences between the two figures lie primarily in the estimates of repository costs. As mentioned above, Weston suggests that the main reason for the difference in the estimates for this cost category is the different assumptions about the variation in burnup levels used in the calculations. In Dippold and Wampler all spent fuel was assumed to have the same burnup level, allowing repository optimization that was not possible under the Weston assumption of varied burnup levels. 
IABLE 4.17. Summary of Estimated 1985 Discounted Back-End cost Savings, 1985-2020, by Data Source and Cost Category (militions of 1985\$)

Activity Granite Granite Granite

\begin{tabular}{cccc} 
& \multicolumn{3}{c}{ Weston (1985) Data } \\
\cline { 2 - 3 } & \multicolumn{2}{c}{ Repository } & Type \\
\cline { 2 - 4 } & Salt & Tuff & Basalt \\
Cost & and & and & and
\end{tabular}

\section{At-Reactor \\ Storage}

Transportation

Repository

TOTAL
47.6

61.8

47.6

70.8

72.4

$$
\underline{-415.0}
$$$$
-305.6
$$

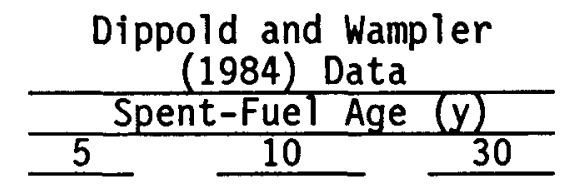

(1984) Data

\begin{tabular}{l} 
Spent-Fuel Age $(y)$ \\
\hline$\quad-30$
\end{tabular}

$[47.6]^{(a)}$

$[47.6]^{(a)}$

(a) Derived from Weston (1985) data for lack of Dippold and Wampler data for this activity.

Another factor bearing on the two sets of estimates is that the Weston data are based on the assumption of two repositories each with a design receipt rate of 3,000 t/y, while the Dippold and Wampler data are based on a single repository with a design receipt rate which declines with higher average burnup levels. As mentioned earlier, the current uncertainties with respect to repository specifications make it imprudent to reject one or the other set of assumptions. For these reasons we interpret the estimates presented here as marking the range of likely outcomes.

\subsection{TOTAL FUEL CYCLE}

In a paper presented to the American Nuclear Society, Murphie and Lang (1982) estimated the net cost savings that could be expected from implementing extended burnup. These savings fall into three categories:

1. direct fuel cost savings including those resulting from both the front end and the back end of the fuel cycle

2. reduced replacement power costs resulting from relaxed plant power maneuvering restrictions from the use of improved fuel [pellet-claddinginteraction (PCI) resistant]

3. system cost savings from lengthened operating cycles facilitated by extended burnup.

With respect to the first category, Murphie and Lang (1982, p. 7-64) conclude the following: 
The direct benefit to the electric consumer of extended burnup in LWR's is a significant fuel cost savings. The projected 30-year levelized fuel cycle cost savings of [DOE 1980b] were escalated to 1981 dollars and used in conjunction with the projected LWR capacities and implementation schedules... This resulted in a projected cumulative savings of $\$ 8.0$ billion for the United States... . in constant 1981 dollars.

The second category refers to the fact that reactor operations are affected by potential PCI problems to the degree that capacity factor (see Glossary) losses in the United States average about $3 \%$ for BWRs and $0.3 \%$ for PWRs (Murphie and Lang 1982, p. 7-64). Reductions in capacity lead to increased purchases of replacement power and, therefore, increased costs. Part of the research associated with extended fuel burnup includes the development of fuel with increased resistance to pellet-cladding interaction problems. Murphie and Lang (1982, p. 7-64) estimate that using this fuel will yield cost savings of $\$ 2.5$ billion (1981 dollars) through the year 2000 .

The third category of cost savings relates to lengthened operating cycles. Longer operating cycles mean that reactors are shut down for refueling less frequently. This leads to higher operating capacity factors, reduced refueling costs, and reduced costs for replacement power. The resulting savings are estimated at $\$ 1.4$ billion in 1981 dollars (Murphie and Lang 1982, p. 7-65). Table 4.18 reports these three savings categories in 1985 dollars.

TABLE 4.18. Estimated Savings Resulting from Implementation of Extended Burnyp) by Category (billions of 1985\$)

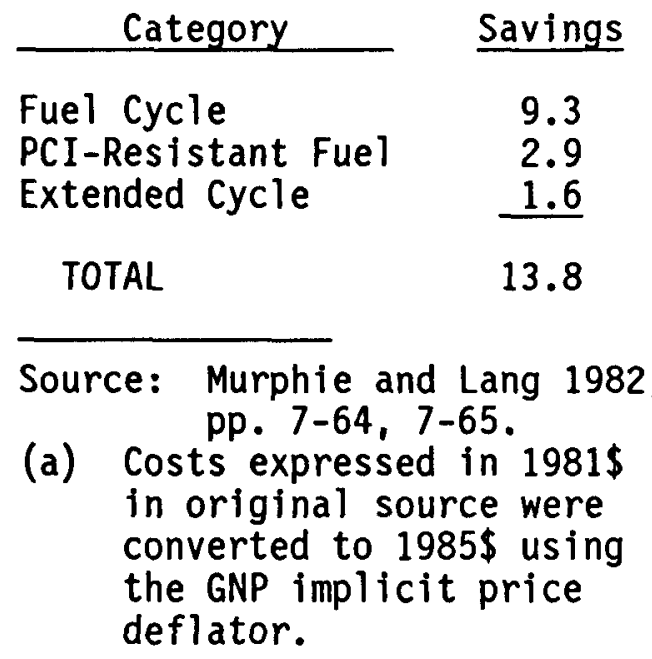

These figures should be viewed with caution for two reasons. First, while the prospects of extended burnup add to the incentives to develop improved fuel, at least a portion of the cost savings in the second category could be realized independently of extended burnup. Second, the literature was unclear as to how or if the future cost savings were discounted. The total savings 
appear to be derived by summing the undiscounted annual amounts. Since the savings over time were not provided, the totals are difficult to interpret. Because the annual savings will be greater in later years and because these savings accrue over a lengthy time period, the totals indicated may exceed the discounted sum by a considerable amount. Discount adjustment factors calculated elsewhere in this report for the sum of undiscounted annual amounts extending over a period of about 30 years range from around 0.18 to about 0.30. If, for example, the appropriate discount adjustment factor is 0.25 , fuel-cycle cost savings would be around $\$ 2.3$ billion, and the total estimated by Murphie and Lang would be an adjusted $\$ 3.5$ billion.

Combining estimates of front-end and back-end cost savings developed here gives a range of total discounted fuel-cycle cost savings of from $\$ 1.98$ to $\$ 2.68$ billion. These amounts are strongly dominated by estimated savings in the front end of the fuel cycle. According to the estimates, this segment of the fuel cycle accounts for over $90 \%$ of the savings.

\subsection{SENSITIVITY ANALYSIS}

The foregoing estimates of the economic effects of implementing extended burnup are based on a wide set of conditions. Some conditions are particularly important in determining the magnitude of the forecasted effects. This section presents a discussion of the factors to which the economic effects of extended burnup are most sensitive.

The front end of the fuel cycle accounts for the overwhelming bulk of the estimated reduction in total costs. However, these front-end cost savings greatly depend on assumed price levels, particularly the uranium price. In fact, much of the original impetus for extended burnup came from the sharp rise in uranium prices in the 1970s. Because extended burnup reduces the need for uranium, the dollar value of reduced uranium requirements is directly linked to the price of uranium. This is stated succinctly by Delene: "The results. . . show a strong dependence of savings on uranium price. The higher the price, the greater the savings" (Delene 1984, p. 21).

The DOE notes that the Franks and Geller results may be affected by uranium prices. Further, it is suggested that the price used by Franks and Geller may be high, resulting in an upward bias in the estimated benefits of extended burnup (DOE 1985a, p. A.3):

An analysis of the Stoller [Franks and Geller 1986] results indicates that a substantial fraction of the predicted fuel cycle cost saving is due to savings in uranium costs. The uranium price projections were made to be representative of uranium purchased by utilities under long-term contracts. The long-term contract prices used in this study are considerably higher than the current spot market price. Utilities make over 90 percent of their uranium purchases under long-term contracts. . . [ [t] should be kept in mind that projected savings would become smaller or larger as uranium prices 
became lower or higher than the projected values. In the Stoller

[Franks and Geller] report the sensitivity of fuel cycle cost savings with respect [to] unit cost values selected is unclear.

other price levels in the front end also have a bearing on cost effects. As mentioned above, there are reasonably good prospects for a substantial decline in the cost of fuel enrichment. Delene, however, finds that "the savings [appear] .. . to be relatively independent of enrichment price" (Delene 1984, p. 21).

Aggregate savings may also potentially be sensitive to fuel-management methods. Work by Brown et al. (1986) indicates that extended burnup combined with the adoption of various optimization measures in fuel management could produce improvements in ore utilization of up to $28.9 \%$ (Brown et al. 1986, p. 7-81).

At the back end of the fuel cycle, the most important factor appears to be the strict requirements for repository design and operation. If these requirements can be relaxed by aging the spent fuel, by changing the minimum repository specifications, or by technical improvement, a significant reduction in back-end costs would result.

Finally, because this issue concerns monetary amounts extending well into the future, the magnitude of the economic effects is highly dependent on the assorted time distribution of these amounts and the discount rate.

A summary of the cost savings resulting from implementing extended fuel burnup is presented in Table 4.19. Shown in the table are the cost savings for different stages in the fuel cycle. The wide range given for some cost categories, most notably repository costs, reflects differences in estimates between primary sources. The total discounted cost savings for the period 1985 to 2020 resulting from implementing extended burnup is estimated to be on the order of $\$ 2$ billion. Almost all of this amount comes from savings in the front end of the cycle. Small cost savings are noted in at-reactor storage and transport of spent fuel. Sources disagree as to the extent of effects of extended burnup on repository costs. After adjustments, the Weston data indicate an increase in repository costs of around $\$ 390$ to $\$ 670$ million (See Table 4.16). Adjusted Dippold and Wampler data imply a modest decrease of around $\$ 78$ to $\$ 94$ million (See Table 4.15). Because the source data contain a number of severe limitations, these estimates must be viewed with caution. Finally, Murphie and Lang (1982), who only provided a total estimate for the entire fuel cycle, estimate total fuel-cycle costs at about $\$ 2.3$ billion, which falls within the range given in Table 4.19. 
TABLE 4.19. Summary of Estimated Discounted cost Savings, 1985-2020, from Extended Fuel Burnup, by Category (millions of 1985\$)

\section{Category}

Front End of Fuel Cycle

Research and Development

Fuel Production and Fuel Management

Subtotal

Back End of Fuel Cycle

Development and Evaluation

At-Reactor Storage

Transportation

Repository

Subtotal

TOTAL FUEL CYCLE
Savings

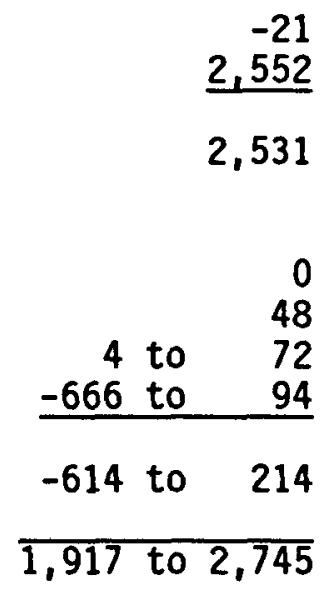




\subsection{REFERENCES}

Andrews, M. G., R. A. Matzie, and N. L. Shapiro. 1985. "Cutting PWR Costs with Advanced In-Core Fuel Management Techniques." Nuclear Engineering International 30(366):34-39.

Babcock and Wilcox. 1982. Extended Burnup Evaluation. Report BAW-10153(P), Babcock and Wilcox, Lynchburg, Virginia.

Bailey, W. J., and M. S. Dunenfeld. 1986. Fuel Performance Annual Report for 1984. NUREG/CR-3950 (PNL-5210), Vol. 2, U.S Nuclear Regulatory Commission, Washington, D.C.

Baily, W. E., M. 0. Marlowe, and R. A. Proebstle. 1985. "Trends in BWR Fuel Performance." In Proceedings of the American Nuclear Society Topical Meeting on Light Water Reactor Fuel Performance, pp. 1-3 through 1-15. DOE/NE/34130-1, Vol. 1, American Nuclear Society, Florida Section, Orlando, Florida.

Berkow, H. N., U.S. Nuclear Regulatory Commission. December 3, 1985, letter to J. H. Taylor, Babcock and Wilcox Company. Subject: "Acceptance for Referencing of Licensing Topical Report BAW-10153P, Extended Burnup Evaluation." Available in NRC Public Document Room.

Brown, P. D. et al. 1986. "Impact of Extended Burnup on the BWR Fuel Cycle." In Proceedings of the American Nuclear Society Topical Meeting on Advances in Fuel Management, pp. 7-71 to 8-80. American Nuclear Society, Eastern Carolinas Section, Pinehurst, North Carolina.

Butcher, E. J., U.S. Nuclear Regulatory Commission. October 10, 1985, letter to A. E. Lundval1, Jr., Baltimore Gas and Electric Co. Subject: "Safety Evaluation Report for Extended Burnup Operation of Combustion Engineering PWR Fuel, CENPD-269-P." Available in NRC Public Document Room.

Charnley, J. S., General Electric Co. February 25, 1983, letter to F. J. Miraglia, U.S. Nuclear Regulatory Commission. Subject: "Proposed Revision to GE Licensing Topical Report NEDE-24011-P-A." Available in NRC Public Document Room.

Charnley, J. S., General Electric Co. October 14, 1983, letter to M. S. Dunenfeld, U.S. Nuclear Regulatory Commission. Subject: "1984 Fuel Experience Report" (with attachment "Experience with BWR Fuel Through December 1984"). Available in NRC Public Document Room.

Combustion Engineering. 1984. Extended Burnup Operation of Combustion Engineering PWR Fuel. Report CENPD-269-P, Revision 1-P, Combustion Engineering, Inc., Windsor Connecticut. 
Congressional Information Bureau, Inc. (CIB). 1982. "Industry Representatives Took Issue with Elements of the Department of Energy's FY 1983 Budget for Nuclear Fission Programs as a House Science Subcommittee Continued its Consideration of DOE's Funding Requests." In Atomic Energy Clearinghouse, 28(12):17. Congressional Information Bureau, Inc., Washington, D.C.

Croff, A. G. 1980. ORIGEN2 - A Revised and Updated Version of the Oak Ridge Isotope Generation and Depletion Code. ORNL-5621, Oak Ridge National Laboratory, Oak Ridge, Tennessee.

Delene, J. G. 1984 (Draft). Fuel Cycle Cost Analysis of Extended Burnup Fuels. Oak Ridge National Laboratory, Oak Ridge, Tennessee. Available in NRC Public Document Room.

Dippold, D. G., and J. A. Wampler. 1984. Spent Fuel Burnup and Age: Implications for the Design and Cost of a Waste Disposal System. BMI/ONWI-561, Office of Nuclear Waste Isolation, Battelle Memorial Institute, Columbus, Ohio.

Electric Power Research Institute (EPRI). 1983. LWR Core Materials Performance Program: Progress in 1981-1982. Report NP-3150-SR, Electric Power Research Institute, Palo Alto, California.

Electric Power Research Institute (EPRI). 1985. LWR Core Materials Performance Program: Progress in 1983-1984. Report NP-4312-SR, Electric Power Research Institute, Palo Alto, Californía.

Exxon Nuclear Company. 1982. Qualification of Exxon Nuclear Fuel for Extended Burnup. Report XN-NF-82-06, Revision 1, Exxon Nuclear Company, Richland, Washington.

Franklin, D. G. 1982. "The Schedule for Extending Fuel Burnup." In Proceedings of the American Nuclear Society Topical Meeting on LWR Extended Burnup Fuel Performance and Utilization, p. 8-10. D0E/NE/34087, Vol. 2, American Nuclear Society, Virginia Section, Lynchburg, Virginia.

Franks, W. A., and L. Geller. 1986. The Benefit of Extended Burnup in Fuel Cycle Cost. The S. M. Stoller Corporation, New York, New York.

General Electric Company. 1982. Extended Burnup Evaluation Methodology. Report NEDE-22148-P, General Electric Company, San Jose, California.

Hulman, L. G., U.S. Nuclear Regulatory Commission. December 20, 1982, memorandum to C. H. Berlinger, U.S. Nuclear Regulatory Commission. Subject: "Reload Reviews in DSI." Avallable in NRC Public Document Room.

Lang, P. M. 1982a. Contribution to "Panel Discussion of Extended Burnup: How Far? How Fast?" In Proceedings of the American Nuclear Society Topical Meeting on LWR Extended Burnup Fuel Performance and Utilization, p. 8-3. DOE/NE/34087, Vol, 2, American Nuclear Society, Virginia Section, Lynchburg, Virginia. 
Lang, P. M. 1982b. "Extending LWR Fuel Burnup." Nuclear Engineering International 27(329):14 (ISSN 0029-5507).

Lang, P. M. 1986. "Effect of DOE-Sponsored Development on LWR Fuel Cycles." In Proceedings of the American Nuclear Society Topical Meeting on Advances in Fuel Management, pp. 7-61 to 7-69. American Nuclear Society, Eastern Carolinas Section, Pinehurst, North Carolina.

Mattsen, C. R., U.S. Nuclear Regulatory Commission. January 3, 1979, memorandum to Files. Subject: "Corrections to Data in 'Attachment $B$ ' of Memo to Files Dated December 6, 1978, Concerning Decay of Spent Fuel." Available in NRC Public Document Room.

Matzie, R. A. 1981. Licensing Assessment of PWR Extended-Burnup Fuel Cycles (Final Report). CEND-381, Combustion Engineering, Inc., Windsor, Connecticut.

Mauro, J. J., R. Eng, S. Marschke, and W. Chang. 1985. The Environmental Consequences of Higher Fuel Burn-up. Prepared for the National Environmental Studies Project, Atomic Industrial Forum, Inc., Bethesda, Maryland.

Murphie, W. E., and P. M. Lang. 1982. "Projected National and World Benefits to the LWR Fuel Cycle from Extended Burnup." In Proceedings of the American Nuclear Society Topical Meeting on LWR Extended Burnup Fuel Performance and Utilization, pp. 7-61 through 7-69. DOE/NE/34087, Vol. 2, American Nuclear Society, Virginia Section, Lynchburg, Virginia.

Nuclear Engineering International (NEI). 1985. "Putting the Heat on PWR Fuel," (editorial). 30(376):21-22.

Nuclear Fuel. 1984. "Ottinger Says Funding for Higher Burnups Would Cut Utility Waste Management Costs," (editorial). 9(4):5.

0ztunali, 0. I., and G. W. Roles. 1986. Update of Part 61 Impacts Analys is Methodology. NUREG/CR-4370, Vol. 1, U.S. Nuclear Regulatory Commission, Washington, D.C.

Pati, S. R., and A. M. Garde. 1985. "Fission Gas Release from PWR Fuel Rods at Extended Burnups." In Proceedings of the American Nuclear Society Topical Meeting on Light Water Reactor Fuel Performance, p. 4-19. DOE/NE/34130-1, Vol. 2, American Nuclear Society, Florida Section, Orlando, Florida.

Planell, J. R., M. Mason, and G. Guerra. 1983. Extended Fuel Burnup Demonstration Program Topical Report - Transport Considerations for Transnuclear Casks. DOE/ET 34014-11, TN-E-4226, Transnuclear, Inc., White Plains, New York.

Pyecha, T. D., G. M. Bain, W. A. McInteer, and C. H. Pham. 1985. "Waterside Corrosion of PWR Fuel Rods Through Burnups of 50,000 MWd/MTU." In Proceedings of American Nuclear Society Topical Meeting on Light Water Reactor Fuel Performance, pp. 3-17 through 3-35. DOE/NE/34130-1, Vol. 1, American Nuclear Society, Florida Section, Orlando, Florida. 
Quigg, C., Pollution \& Environmental Problems, Inc. March 6, 1980, letter to S. J. Chilk, U.S. Nuclear Regulatory Commission. Subject: "Petition for Rulemaking on Generic Impacts of High Burnup Nuclear Fuel." Available in NRC Public Document Room.

Risher, D. H., et al. 1977. Safety Analysis for the Revised Fuel Rod Internal Pressure Design Basis. WCAP-8963 (Proprietary) and WCAP-8964 (NonProprietary), Westinghouse Electric Corp., Pittsburgh, Pennsylvania.

Roberts, E. 1982. "Extended Burnup Considerations and Experience." In Proceedings of the American Nuclear Society Topical Meeting on LWR Extended Burnup Fuel Performance and Utilization, pp. 1-1 through 1-3. DOE/NE/34087, Vol. 1, American Nuclear Society, Virginia Section, Lynchburg, Virginia.

Rogovin, M. (Dir). 1980. Three Mile Island-A Report to the Commissioners and to the Public. NUREG/CR-1250, Vol. II, Part 2, U.S. Nuclear Regulatory Commission, Washington, D.C.

Rosenstein R. G. et al. 1986. "24-Month Fuel Cycles." In Proceedings of the American Nuclear Society Topical Meeting on Advances in Fuel Management. American Nuclear Society, Eastern Carolinas Section, Pinehurst, North Carolina.

Rossi, C. E., U.S. Nuclear Regulatory Commission. July 18, 1986, letter to G. N. Ward, Exxon Nuclear Co. Subject: "Acceptance for Referencing of Licensing Topical Report XN-NF-82-06(P), Rev. 1, Qualification of Exxon Nuclear Fuel for Extended Burnup." Available in NRC Public Document Room.

Roy F. Weston, Inc. (Weston). 1985. The Effects of Extended Nuclear Fuel Burnup on the Waste Management System. Roy F. Weston, Inc., Rockville, Maryland.

Rubenstein, L. S., and M. Tokar. 1982. "Regulatory Perspective on Extended Burnup Fuel." In Proceedings of the American Nuclear Society Topical Meeting on LWR Extended Burnup Fuel Performance and Utilization, pp. 6-31 through 6-37. DOE/NE/34087, Vol. 2, American Nuclear Society, Virginia Section, Lynchburg, Virginia.

Silberberg, J.A., et al. 1986. Reassessment of the Technical Bases for Estimating Source Terms. NUREG-0956, U.S. Nuclear Regulatory Commission, Washington, D.C.

Stoltz, J. F., U.S. Nuclear Regulatory Commission. May 19, 1978, letter to T. M. Anderson, Westinghouse Electric Corporation. Subject: "Safety Evaluation of WCAP-8963." Available in NRC Public Document Room.

Thomas, C. 0., U.S. Nuclear Regulatory Commission. March 1, 1985a, letter to J. S. Charnley, General Electric Co. Subject: "Acceptance for Referencing of Licensing Topical Report NEDE-24011-P, Amendment 7 to Revision 6, General Electric Standard Application for Reactor Fuel." Available in NRC Public Document Room. 
Thomas, C. O., U.S. Nuclear Regulatory Commission. May 9, 1985b, letter to J. S. Charniey, General Electric Co. Subject: "Acceptance for Referencing of Licensing Topical Report NEDE-24011-P. Amendment 7 to Revision 6, General Electric Standard Application for Reactor Fuel; SER Page Changes for Clarification." Available in NRC Public Document Room.

Thomas, C. 0., U.S. Nuclear Regulatory Commission. August 13, 1985c, to J. S. Charnley, General Electric Co. Subject: "Acceptance for Referencing of Licensing Topical Report NEDE-22148-P, Extended Burnup Evaluation Methodology." Available in NRC Public Document Room.

Thomas, C. 0., U.S. Nuclear Regulatory Commission. October 11, 1985d, letter to E.P. Rahe, Westinghouse Electric Corp. Subject: "Acceptance for Referencing of Licensing Topical Report WCAP-10125P, Extended Burnup Evaluation of Westinghouse Fuel." Available in NRC Public Document Room.

Turner, S. E., et al. 1982. Background and Derivation of ANS 5.4 Standard Fission-Product Release ModeT. NUREG/CR-2507, U.S. Nuclear Regulatory Commission, Washington, D.C.

U.S. Department of Energy (DOE). 1980a. Environmental Assessment, DOE Program to Improve Uranium Utilization in Light Water Reactors. DOE/EA-0118, U.S. Department of Energy, Washington, D.C.

U.S. Department of Energy (DOE). 1980b. Nonproliferation Alternative Systems Assessment Program (NASAP). Vol. IX of Reactor and Fuel Cycle Description. DOE/NE-0001/9, U.S. Department of Energy, Washington, D.C.

U.S. Department of Energy (DOE). 1985a. A Study of the Costs and Benefits of Extended Burnup. Office of Nuclear Energy, Office of Civilian Radioactive Waste Management, U.S. Department of Energy, Washington, D.C.

U.S. Department of Energy (DOE). 1985b. Mission Plan for the Civilian Radioactive Waste Management Program. DOE/RW-0005, Vol. I, II, and III, Office of Civilian Radioactive Waste Management, U.S. Department of Energy, Washington, D.C.

U.S. Department of Energy/Energy Information Administration (DOE/EIA). 1985. Commercial Nuclear Power: Prospects for the United States and the World. DOE/EIA-0438(85), U.S. Department of Energy, Washington, D.C.

U.S. Nuclear Regulatory Commission (NRC). 1972. Assumptions Used for Evaluating the Potential Radiological Consequences of a Fuel Handling Accident in the Fuel Handling Storage Facility for Bolling and Pressurized Water Reactors. Regulatory Guide 1.25, U.S. Nuclear Regulatory Commission, Washington, D.C.

U.S. Nuclear Regulatory Commission (NRC). 1974a. Assumptions Used for Evaluating the Potential Radiological Consequences of a Loss of Coolant Accident for Boiling Water Reactors. Regulatory Guide 1.3, Rev. 2, U.S. Nuclear Regulatory Commission, Washington, D.C. 
U.S. Nuclear Regulatory Commission (NRC). 1974b. Assumptions Used for Evaluating the Potential Radiological Consequences of a Loss of Coolant Accident for Pressurized Water Reactors. Regulatory Guide 1.4, Rev. 2, U.S. Nuclear Regulatory Commission, Washington, D.C.

U.S. Nuclear Regulatory Commission (NRC). 1981. Standard Review Plan for the Review of Safety Analysis Reports for Nuclear Power Plants -- LWR Edition. NUREG/0800, Rev 2, U.S. Nuclear Regulatory Commission, Washington, D.C.

U.S. Office of Management and Budget (OMB). 1972. Discount Rates to be Used in Evaluating Time Dependent Costs and Benefits. Circular A-94, U.S. Office of Management and Budget, Washington, D.C.

Viebrock, J. M., and R. A. Schreiber. 1983. Extended Fuel Burnup Demonstration Program - Nuclear Assurance Corporation Final Report. DOE/ET/34014-10, NAC C-8327, Nuclear Assurance Corporation, Norcross, Georgia.

Westinghouse Electric Corporation. 1982. Extended Burnup Evaluation of Westinghouse Fuel. Report WCAP-1-10125, Westinghouse Electric Corporation, Pittsburgh, Pennsyivania. 


\section{APPENDIX A}

FUEL ACTIVITY INVENTORY CALCULATIONAL PARAMETERS 


\section{APPENDIX A}

\section{FUEL ACTIVITY INVENTORY CALCULATIONAL PARAMETERS}

To determine the activity inventory for various burnup levels and times after shutdown, the Oak Ridge Isotope Generation and Depletion Code, ORIGEN2, was used (Croff 1980). From the resulting inventory, the changes in activities for the various nuclides were determined as the burnup level was increased from 33 to $60 \mathrm{GWd} / \mathrm{t}$. The specific masses of the elements and uranium isotopes in grams per tonne of fuel making up a new fuel assembly are utilized in the code. These parameters, which are given in Table A.1, determine the resulting activity levels in the fuel at various exposure times. Only those elements having specific masses greater than $30 \mathrm{~g} / \mathrm{t}$ are listed in the table. The assumption was made that the fuel was used in a typical pressurized water reactor operating at a specific power level of $37.5 \mathrm{MW} / \mathrm{t}$.

TABLE A.1. ORIGEN2 Input Specific Masses $(g / t)$ for Burnup Levels of 33 and $60 \mathrm{GWd} / \mathrm{t}$

\begin{tabular}{|c|c|c|}
\hline Element & 33 & 60 \\
\hline $\begin{array}{l}\text { Carbon } \\
\text { Nitrogen }\end{array}$ & $\begin{array}{r}129.46 \\
55.88\end{array}$ & $\begin{array}{r}129.46 \\
55.88\end{array}$ \\
\hline oxygen & 134,667 & 134,667 \\
\hline Aluminum & 99.1 & 99.1 \\
\hline $\begin{array}{l}\text { Silicon } \\
\text { Phosphorous }\end{array}$ & $\begin{array}{l}138.03 \\
307.52\end{array}$ & $\begin{array}{l}138.03 \\
307.52\end{array}$ \\
\hline Titanium & 108.12 & 108.12 \\
\hline Chromium & $4,984.5$ & $4,984.5$ \\
\hline Manganese & 230.02 & 230.02 \\
\hline Iron & $9,442.6$ & $9,442.6$ \\
\hline Cobalt & 72.3 & 72.3 \\
\hline Nickel & $9,572.3$ & $9,572.3$ \\
\hline Zirconium & $218,341.8$ & $218,341.8$ \\
\hline Niobium & 710.8 & 710.8 \\
\hline Molybdenum & 394 & 394 \\
\hline Tin & 3,572 & 3,572 \\
\hline Urani um-234 & 320 & 480 \\
\hline Urani um-235 &, 450 & 52,920 \\
\hline Urani um-238 & 964,230 & 946,600 \\
\hline
\end{tabular}


APPENDIX B

COST ADJUSTMENT METHODOLOGY 


\section{APPENDIX B}

\section{COST ADJUSTMENT METHODOLOGY}

This appendix describes in detail the methods for adjusting data used in Chapter 4.0 to gauge the economic effects of implementing extended fuel burnup. The most common adjustment was the conversion of the reported cost data to a 1985 present value based on a $10 \%$ discount rate. Data from Weston (1985) and Dippold and Wampler (1984) are undiscounted sums of annual amounts. Cost figures from Franks and Geller (1986) are discounted at $7.813 \%$. The adjustment for the front-end costs (Franks and Geller 1986) is described in Section B.1; the adjustment for the back-end costs (Weston 1985; Dippold and Wampler 1984) is described in Section B.2. In addition, adjustments to the repository storage cost data are described in Section B.3.

\section{B.1 ADJUSTMENTS TO FRONT-END COST DATA}

As explained in Section 4.2.4 of this report, the Franks and Geller (1986) data on front-end costs are not completely consistent with the needs of this report. This section describes the steps taken to adjust the data for two of these problems. The first of these problems is that these data are based on a discount rate of $7.813 \%$ rather than the $10 \%$ rate assumed here. The second problem is that revisions in the DOE/EIA (1985) middle-growth forecasts are not reflected in the Franks and Geller data. In addition to these, two minor adjustments to the data are described in Section 4.2.4.

To adjust the Franks and Geller data to a $10 \%$ discount rate, the procedure outlined in Section 4.1 was used. First, a time profile for the Franks and Geller figures was generated. The method for doing this is based on the assumption that the cost savings are a positive function of both the total U.S. nuclear generating capacity and the increase in average burnup levels.

This assumption is the basis for the following formula, which is developed and used here to calculate an annual relative cost index:

$$
I_{i}=C_{j}\left[(2 / 3)\left(E_{p i} / B_{p i}-1\right)+(1 / 3)\left(E_{b i} / B_{b i}-1\right)\right]
$$

where $I=$ index of relative cost savings

$1=$ year

$C=$ index of U.S. nuclear-generating capacity

$E=$ average burnup level with extended burnup/research

$\mathrm{p}=\mathrm{PWR}$

$B=$ base level average burnup level (no extended burnup/no research)

$\mathrm{b}=\mathrm{BWR}$. 
Reflecting Franks and Geller as closely as practicable, this formula accounts for the separate time patterns of PWR and BWR burnup levels. The weights $(2 / 3)$ and $(1 / 3)$ are Franks and Geller's estimate of the relative aggregate generating capacity of PWRs and BWRs, respectively.

To estimate a series of indexes, $I_{1}$, that will have a time profile similar to the time profile of the cost savings imbedded within the Franks and Geller work, the ratio of the burnup level attained with DOE-funded research to the burnup level attained without the research was calculated for each year. One was subtracted from these ratios to give a base of zero rather than one. The weighted sum of these ratios was scaled (multiplied) by forecasted U.S. nuclear generating capacity. The figures used for the nuclear generating capacity are those used by Franks and Geller, rather than the latest ones available.

Once these annual indexes were calculated, it was possible to work backward from the $\$ 550$ million to establish a series of annual cost savings using a discount rate of $7.813 \%$ and a time profile corresponding to the calculated indexes. After this series of annual, undiscounted amounts was computed, each annual cost savings figure was adjusted to reflect the extended burnup/no extended burnup comparison, rather than the research/no research comparison from which Franks and Geller derived their figures. This was done by calculating another series of indexes using the same formula as above. This time, however, the ratio of burnup levels was based on levels attained with and without extended burnup, and the revised rather than the older forecast figures for U.S. nuclear generating capacity are used. As expected, each of the second set of ratios was greater than the corresponding ratio of the first set.

Next, the second ratio was divided by the first. This third ratio was then multiplied by the annual amount previously calculated. The result was an estimate of the annual cost savings reflecting the revised capacity projection and the change in basis of comparison. Finally, these newly calculated annual amounts were discounted at $10 \%$ to generate an estimate of the 1985 present value of the cost savings. Applying the above-described process gives an estimated cost savings of $\$ 2.6$ billion.

\section{B.2 ADJUSTMENTS TO BACK-END TRANSPORTATION COST DATA}

The data supplied by Weston (1985) and Dippold and Wampler (1984) on back-end transportation costs and presented in Tables 4.10 and 4.11 of Section 4.3.3 represent undiscounted totals for the years 1984 to 2020 . This section describes the specific method used to calculate the 1985 present value equivalent of the reported cost savings using a $10 \%$ discount rate. This follows the procedure outlined in Section 4.1 .

To calculate the present value, we needed to estimate the approximate time profile of transportation cost savings. This was done by assuming that the cost savings in transportation are a function of two time series: the planned total repository receipt rates and the average fuel burnup levels of transported fuel. Since the latter data are not reported, we used instead the average burnup level of fuel at the time of discharge. Because the spent fuel will be stored at the reactor site for several years, the discharge burnup 
level of the prior five years was used. For example, the average burnup level of fuel discharged in the year 1995 was used as an estimate of the average burnup level of fuel shipped in the year 2000.

From these data we produced a time profile of the transportation cost savings. First, for each year, the average burnup level under the extended burnup scenario was divided by the average burnup level under the base (normal) burnup scenario. Then each of these ratios was multiplied by the planned repository receipt rate for that year. The result for any year is the repository receipt rate for an equivalent amount of normal-burnup fuel, where equivalency is measured in terms of the quantity of electricity produced by the fuel. The difference between the equivalent repository receipt rate and the planned repository receipt rate is a measure of the quantity of fuel that does not have to be transported.

The equivalent repository receipt rates were then used to construct an index. First, the rates were normalized so that they sum to 1.0 . If the rate in each year, $i$, is denoted by $w_{j}$, then a discount adjustment factor, $F$, is derived from the following formula:

$$
F=\sum_{i} w_{i} /(1.1)^{1}
$$

The value obtained for $F$ is 0.0845 . The cost savings do not begin until the year 1998, when the first repository is scheduled to begin, and they increase each year until 2010.

\section{B.3 ADJUSTMENTS TO REPOSITORY STORAGE COST DATA}

In Section 4.3.4 repository cost data from Weston (1985) and from Dippold and Wampler (1984) are presented. Since these figures represent undiscounted totals, however, it was necessary to calculate an equivalent 1985 present value based on a $10 \%$ discount rate. The steps for doing this follow the method outlined in Section 4.1 and are described in detail here. Two discount adjustment factors were generated for the Weston cost estimates, one for each of the two repositories. A single discount adjustment factor was calculated for the Dippold and Wampler cost figures.

Again, it was necessary to estimate a time profile for repository costs. This was accomplished in the following manner: using the Weston figures, the capital costs for the first repository were assumed to be levelized over the period 1987 to 1998, which is before the first repository is scheduled to begin operating. The operations costs were levelized over the period 1998 to 2020, and the costs of repository closure were assigned to the year 2020 . This schedule of costs yields a discount adjustment factor of 0.2385 for the first repository. This factor was applied to tuff and basalt repository types as well as salt, because their cost schedules do not differ greatly. 
A similar allocation was used for costs of the second (granite) repository. Capital costs were levelized over the period 1990 through 2005; operations costs over the period 2005 to 2020; and closure costs were assigned to the year 2020. The resulting discount adjustment factor for costs associated with the second repository is 0.1770 . The discount adjustment factor for the combined costs of the first and second repositories is 0.2036 . This factor is applied to the Dippold and Wampler cost figures. 


\section{DISTRIBUTION}

No. of

Copies

\section{OFFSITE}

10 M. R. Fleishman

Office of Nuclear Regulatory Research

U.S. Nuclear Regulatory Commission

Washington, D.C. 20555
No. of

Copies

ONSITE

33 Pacific Northwest Laboratory

W. J. Bailey

D. A. Baker (10)

C. E. Beyer

F. C. Bold

V. L. Brouns

J. B. Brown, Jr.

D. W. Dragnich

M. D. Freshley

M. J. Graham

J. M. Hales

P. C. Hays

R. J. Moe

M. F. Mullen

T. L. Page

R. G. Schreckhise

R. J. Sorenson

J. J. Tawil

Publishing Coordination (2)

Technical Report Files (5) 


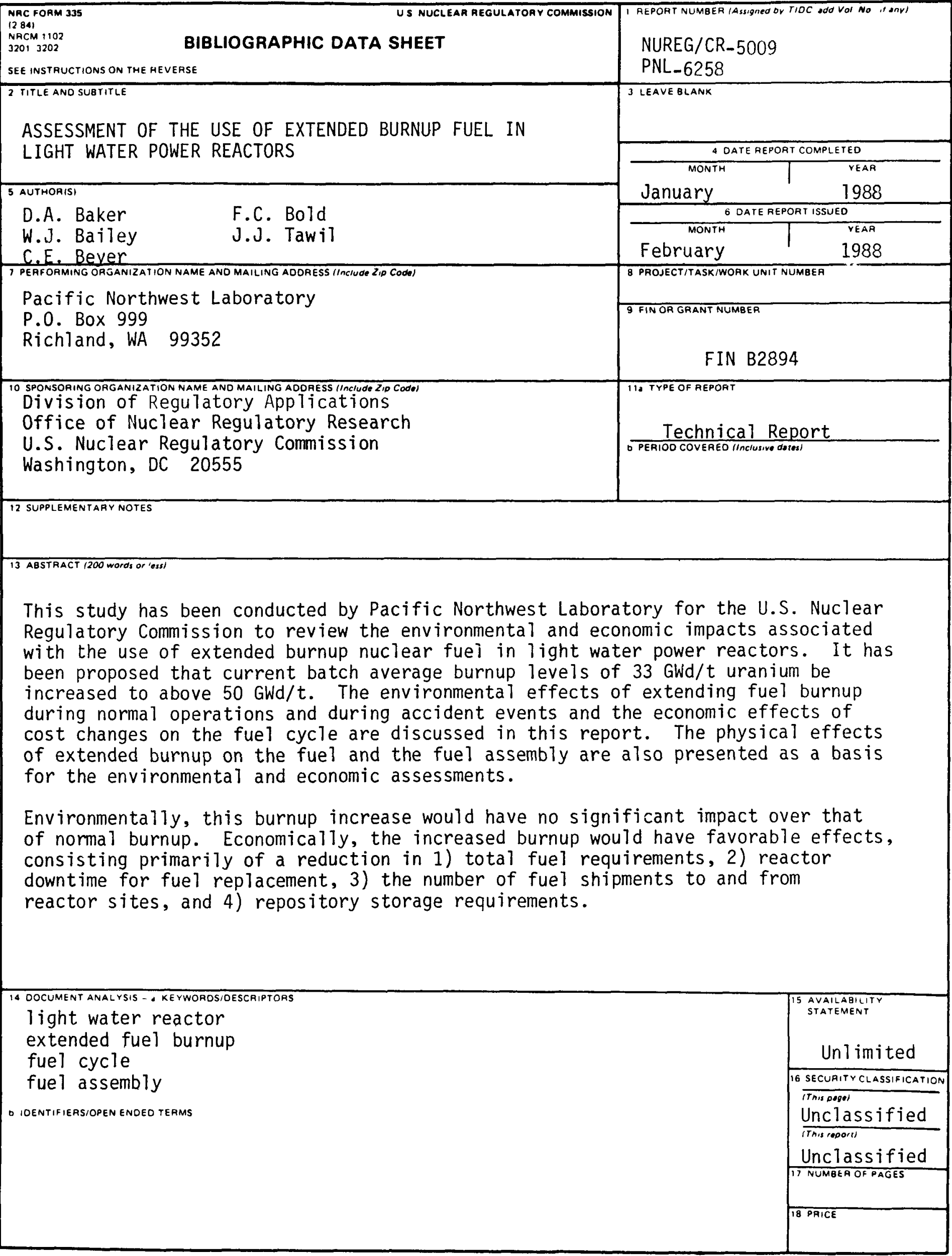

